\title{
Bibliográfia
}

\section{A 2014-ben megjelent, jog- és államtudományi tárgyú könyvek annotált bibliográfiája}

\section{1. rész}

Folyóiratunkban rendszeresen jelenik meg az elmúlt időszak új, hazai szakkönyveiről készült, annotált bibliográfia. Az annotáció a könyv felhasználhatóságáról írott, rövid, tényszerű leírás, amely a bibliográfiai adatok mellett meghatározza a múfajt, illetve röviden körvonalazza a feldolgozott témát és a bemutatott eredményeket is. A mostani számban a 2014-ben megjelent könyvek első részét dolgozzuk fel. Annak megfelelően, hogy a Magyar Tudományos Művek Tára (MTMT) csak a 120 oldal terjedelmet elérő munkákat kezeli önálló kiadványként, az ettől jelentősen elmaradó kiadványokkal mi sem foglalkozunk. A bemutatás jogterületenként történik, a jogterületek elnevezésének, az egyes jogterületeken belül pedig a szerzők (szerkesztők) nevének ábécérendjében következik.

Első lépésként ezúttal is egy listát állítottunk össze különböző intézményi könyvtári katalógusok, a Magyar Országos Közös Katalógus (MOKKA), illetve az Országos Széchényi Könyvtár interneten is közölt adatai alapján. Emellett kiadók honlapján, hírlevelekben, a szerzők publikációs listáiban és saját könyvespolcainkon is kutattunk. Gyűjtőmunkánkat jelentős mértékben segítette a Debreceni Egyetem Egyetemi és Nemzeti Könyvtára (DEENK), amely köteles könyvtárként a hazai kiadványok gyűjtését, feldolgozását, illetve részben - a mienkhez képest némileg eltérő szempontok szerint - annotálását is elvégzi. 2014-től kezdve a DEENK Társadalomtudományi Könyvtár (2016 januárjától DEENK Kassai úti Campus Könyvtára) munkatársai egyéb adatbázisokat is figyelembe véve egészítik ki a listánkat, így az még pontosabb és teljesebb a korábbiaknál. Külön köszönettel tartozunk nekik érte.

A leírások elkészítése során általában a szerzők, kiadók által készített fülszövegeket, ajánlásokat, illetve a kötetekröl készült recenziókat is igyekszünk fellelni és hasznosítani. Az annotációk azonban minden esetben úgy készültek, hogy magát az adott könyvet is a kezünkbe vettük, s ehhez, ha kellett, könyvtárközi kölcsönzéssel vagy más intézményekben dolgozó kollégáktól megkértük. Az annotációk tehát önálló feldolgozó munka eredményei.

Tisztában vagyunk azzal, hogy a feldolgozás szempontrendszere legjobb igyekezetünk ellenére is hiányos, illetve a sok szakterület és közremüködő okán egyenetlen. Örömmel veszünk és meg is szívlelünk ezért minden észrevételt, amely munkánkra vonatkozóan szerkesztőségünkhöz beérkezik. Szívesen fogadjuk azt is, ha a szerzők figyelmünkbe ajánlják saját könyvüket. 
A leírások első, rövidebb része tartalmazza a könyvészeti adatokat (cím, szerző/szerkesztő, a kiadó neve, a kiadás helye és éve) az arra való utalással, hogy van-e a könyvben bibliográfia (irodalomjegyzék), illetve hogy a könyv milyen müfajba sorolható be. A terjedelmet oldalszámban adjuk meg, s közöljük a kötet azonosítására szolgáló ISBN-t, illetve sorozatok esetében az ISSN-t is. A második rész röviden leírja az alkotót, illetve alkotókat. Ezt követően (a változatlan utánnyomások kivételével) általában 6-12 sor terjedelemben számba vesszük a mü tárgyköreit, föbb eredményeit. Az eredmények részletes értékelését azonban nem végezzük el. A sokszerzős, illetve a gyűjteményes munkák esetében nem kerül sor valamennyi szerző név szerinti megemlítésére, $s$ a tanulmányok számától, tematikai egymáshoz kapcsolódásától függ, hogy minden témát megnevezünk-e. A felsőoktatási tananyagok, jogszabályközlések bemutatását a lehetö legtömörebben végezzük el.

Az annotációk szerzői valamilyen formában kivétel nélkül kapcsolódnak a Debreceni Egyetem Állam- és Jogtudományi Karához, legyen szó munkatársainkról, óraadóinkról vagy jelenlegi és volt hallgatóinkról. Az annotációk végén szereplő monogramok feloldása a következő: Antal Zsófia (A. Zs.) joghallgató, Balogh Éva (B. É.) PhD-hallgató, Bagdi Katalin (B. K.) PhD-hallgató, Bányai Orsolya (B. O.) egyetemi adjunktus, Barta Attila (B. A.) egyetemi adjunktus, Becánics Adrienn (Be. A.) egyetemi tanársegéd, Bordás Péter (B. P.) PhD-hallgató, Bujdos Ágnes (B. Á.) tudományos segédmunkatárs, Deák Izabella (D. I.) igazgatásszervező hallgató, Csaholczi Erika (Cs. E.) PhD-hallgató, Csonka Réka (Cs. R.) joghallgató, Deák Viktória (D. V.) PhD-hallgató, Fekete Péter Pál (F. P. P.) joghallgató, Fodor László (F. L.) egyetemi tanár, Gócza Ágnes (G. Á.) PhD-hallgató, Gyurkó Brigitta (Gy. B.) joghallgató, Gyüre Annamária Csilla (Gy. A. Cs.) tudományos segédmunkatárs, Hadházi Dávid (H. D.) joghallgató, Hutóczki Katalin (H. K.) joghallgató, Kapás Bendegúz (K. B.) igazgatásszervező hallgató, Kazsamér Katalin Enikő (K. K. E.) joghallgató, Kémeri Zsófia Eszter (K. Zs.) egyetemi tanársegéd, Kömüves Barbara (K. Ba.) PhD-hallgató, Liptai Noémi (L. N.) PhD-hallgató, Molnár Judit (M. J.) egyetemi adjunktus, Molnár Tamás (M. T.) PhD-hallgató, Nyilas Anna (Ny. A.) egyetemi adjunktus, Papp Eszter (P. E.) igazgatásszervező hallgató, Papp Nikolett (P. N.) egyetemi tanársegéd, Papp Olga Katalin (P. O.) PhD-hallgató, Pribula László (P. L.) egyetemi docens, Rácz András (R. A.) joghallgató, Sarkadi Imre (S. I.) PhD-hallgató, Sütö Bianka (S. B.) PhD-hallgató, Szabó Zsanett (Sz. Zsa.) PhD-hallgató, Szendrői Anna (Sz. A.) joghallgató, Széles Krisztina (Sz. K.) joghallgató, Szilágyi Gábor (Sz. G.) joghallgató, Szilágyi Szabolcs (Sz. Sz.) joghallgató, Tomasovszky Edit (T. E.) PhD-hallgató, Varga Judit (V. J.) egyetemi tanársegéd, Veszprémi Bernadett (V. B.) egyetemi adjunktus, Zsugyó Virág (Zs. V.) PhD-hallgató.

\section{ALKOTMÁNYJOG}

- Centralizált Magyarország - megtépázott jogvédelem. A hatalommegosztás rendszerének változásairól (2010-2014) 
Monográfia. Terjedelem: 544. Bibliográfia: 510-544. és a lábjegyzetekben. ISBN 9789632445052

- A szerző országgyülési képviselő. Magyarországon 2010 és 2014 között olyan mértékü közjogi átalakulás ment végbe, amelyhez hasonlót a rendszerváltás óta nem tapasztaltunk. A kötet ennek a ciklusnak a jogalkotási gyakorlatát elemzi. A kötet egyediségét az adja, hogy a szerző e folyamatnak részese is volt, így az elméleti kutatások mellett saját tapasztalatokkal is rendelkezi a közjogi átalakítás eseményeiről. A szerző a bevezető, alapvető fejezetet követően az alkotmányos intézményrendszer átalakítását mutatja be. Szól az Országgyűlésre, az országos népszavazásra, az országos hatáskörü választási bizottságra, a köztársasági elnökre, a helyi önkormányzatokra és a közpénzügyekre vonatkozó szabályozás változásáról. Részletesen bemutatja az Alkotmánybíróságot, a bíróságokat, az ügyészséget és az alapvető jogok biztosát érintő változásokat. Végül a közhatalmon kívül egyéb hatalmi tényezőket és a hazánkat érintő nemzetközi vizsgálatokat, és az azok során született határozatokat mutatja be. A kötethez Fleck Zoltán írt előszót. (B. É.)

- Összehasonlító alkotmányjog: fejezetek az alkotmány, az állam, az államszervezet és az alapvető jogok témaköréböl

Bende Zsófia-Halász Iván (szerk.)

Nemzeti Közszolgálati Egyetem Közigazgatás-tudományi Kar, Budapest, 2014

Egyetemi jegyzet. Terjedelem: 184. Bibliográfia: 177-183. és a lábjegyzetekben. ISBN 9786155344510

- A szerkesztők egyetemi oktatók. A kötet célja, hogy főként az államszervezeti kérdésekre, illetve az emberi jogok nemzetközi garanciális aspektusaira koncentrálva nyújtson betekintést a modern alkotmányjogba. A szerzők törekedtek arra, hogy Európa államainak megoldásain túl a világ más államainak alkotmányos gyakorlatából is szemléltessenek néhányat. A jegyzet az alkotmány fogalmának és típusainak, illetve az alkotmányozás sajátosságainak bemutatásával kezdődik. Ezt követően az állam és jelképei, az államok típusai, az államformák és az államfők típusai, a kormányformák, a parlament és a törvényhozás, a választások és a választási rendszerek, az alkotmánybíráskodás modelljei, az emberi jogok védelmének nemzetközi rendszere, végül az állam és az egyház kapcsolatának lehetséges alapmodelljei kerülnek bemutatásra. (B. É.)

- A választójog alapjogi tartalma és korlátai

BodNÁR Eszter

HVG-ORAC, Budapest, 2014

Monográfia. Terjedelem: 366. Bibliográfia: 351-364. ISBN 9789632582177

- A szerző egyetemi oktató, a könyv a szerző azonos címü, 2013-ban megvédett doktori értekezésén alapul. A választójog kettős természetéből indul ki: a választójog egyrészt a népképviseleti szervek létrehozásának eszköze, másrészt alapjogi jellege van. A szerző célkitűzése, hogy a választójogot alapjogi megközelítésből vizsgálja, és annak alapjogi tartalmát és határait mutassa be. Elsőként a választójog alkotmányos demokráciákban betöltött szerepét ismerteti, ezt követően a 
választójog alapjogi jellemzőit mutatja be. Ennek keretében kitér a választójog igazolásaira, illetve az alapjogi jellegét alátámasztó fogalmi elemek meghatározására és a választójog részjogosultságaira. Ezután a választójog korlátozását elemzi részletesen. Végül a választójog mint alapjog védelme kerül bemutatásra. (B. É.)

- Alkotmányjog: Jogi szakvizsga kézikönyvek

Csink Lóránt (szerk.)

(Sorozat: Jogi szakvizsga kézikönyvek, ISSN 1786-0806)

Második kiadás. Novissima, Budapest, 2014

Tansegédlet. Terjedelem: 225. Bibliográfia nincs. ISBN 9786155499029

- A szerkesztő és a szerzők egyetemi oktatók. A könyv elsősorban a szakvizsgára készülők számára nyújt segítséget alkotmányjogból. Az egyes fejezetek a szakvizsga-követelmények alapján dolgozzák fel az alkotmányjogi tananyagot. Az alapjogok, a választójog és a nemzetiségi jogok tematikus feldolgozását követik az állampolgársági jog szabályai, illetve a népszavazásra és az európai polgári kezdeményezésre vonatkozó rendelkezések ismertetése. Ezt követően az emberi jogok nemzetközi védelmének rendszere, a jogalkotásra vonatkozó szabályok, a nemzetközi jog és az Európai Unió jogának a belső joghoz való viszonya kerül bemutatásra. Az államszervezetet alkotó szervek egyenként, önálló fejezetben szerepelnek. A joganyag értelmezésének megkönnyítése érdekében feldolgozásra kerültek a vonatkozó alkotmánybírósági határozatok is. (B. É.)

\section{- Mozaikok a hatalommegosztáshoz}

Csink Lóránt

(Sorozat: A Pázmány Péter Katolikus Egyetem Jog- és Államtudományi Karának Könyvei. Jogtudományi Monográfiák, 5.; ISSN 2061-5191)

Pázmány Press-PPKE JÁK, Budapest, 2014

Monográfia. Terjedelem: 195. Bibliográfia: 181-195. és a lábjegyzetekben. ISBN 9789633081877

- A szerző egyetemi oktató. Az állam szerkezeti felépítését a puzzle-hoz hasonlítja. Mind az államszervezet, mind a puzzle esetében igaz ugyanis, hogy vannak elöre meghatározott darabok, és az egyes elemek az összeillesztést követően válnak értelmessé. Az Alaptörvény a magyar államszervezet puzzle-ját összekeverte, bizonyos darabokat elvett, amelyeket más elemekkel pótolt. Így az állam működésének feltárásához ezeket újra kell rendezni. A mü nem vállalkozik az egész puzzle kirakására, nem kívánja az egész államszervezet működését bemutatni. A szerző célja, hogy az elméleti alapok segítségével mutassa be az Alaptörvény által létrehozott alkotmányos berendezkedés hatalmi ágait és a hatalmi tevékenységet gyakorló intézményeket. A szerző a 2013. október 15-éig megjelent jogszabályokat és szakirodalmat dolgozta fel. (B. É.)

- Alkotmány, alkotmányosság

Martin Opitz, Budapest, 2014 
Konferenciakötet. Terjedelem: 195. Bibliográfia a lábjegyzetekben. ISBN 9789639987142

- A szerkesztők egyetemi oktatók. 2010. november 23-án az ELTE Állam- és Jogtudományi Kar, az Amerikai Egyesült Államok Nagykövetsége és a Magyar Alkotmányjogászok Egyesülete tudományos konferenciát rendezett „Alkotmány - alkotmányosság" címmel. A konferencia célkitűzése az volt, hogy az új alkotmány koncepciójáról párbeszéd alakuljon ki az alkotmány előkészítői és az alkotmányjogászok között. A kötet a konferencián elhangzott elöadások tanulmánnyá átdolgozott változatát tartalmazza, Király Miklós nyitóbeszédével kezdődik, melyet Sólyom László írása követ. Ezután a kötet két nagy szerkezeti egységre tagolódik. Az I. rész „Az alkotmányozás történeti modelljei- $A z$ alkotmányozás sarokkövei" címet viseli. Ebben olvashatóak többek között Bragyova András, Sári János, Trócsányi László tanulmányai. A II. rész „Az alkotmány stabilitása, az alkotmány védelme" címet viseli. Itt találhatóak például Paczolay Péter, Holló András, Salamon László írásai. A kötethez Kukorelli István írt zárszót. (B. É.)

- Alkotmányozás és alkotmányjogi változások Európában és Magyarországon Gárdos-Orosz Fruzsina-Szente Zoltán (szerk.) Nemzeti Közszolgálati Egyetem Közigazgatás-tudományi Kar, Budapest, 2014 Tanulmánykötet. Terjedelem: 340. Bibliográfia a lábjegyzetekben. ISBN 9786155491436

- A tanulmánykötetnek tizenhat szerzője van, akik a Nemzeti Közszolgálati Egyetem Közigazgatás-tudományi Karának Közjogi Intézetében létrehozott „Alkotmányozás és alkotmányos változások" kutatómühely tagjai. A kötet célja, hogy tudományos igénnyel elemezze a jelenkori európai alkotmányozás fő folyamatait, kihívásait, s mindezek tükrében értékelje a magyarországi alkotmányos változásokat. A mű első részében az alkotmányozás elméleti alapjairól értekeznek a szerzők. A második rész az alkotmányozás jelenkori mintáit és korlátait mutatja be. A harmadik rész az alkotmányellenes alkotmánymódosítások elvi problémáit vizsgálja. Végül, a negyedik rész Magyarország új alkotmányos berendezkedésének alapvető kérdéseivel foglalkozik. (Sz. Sz.)

- Autonomies in Europe: Solutions and Challenges

Kántor Zoltán (szerk.)

NPKI-L'Harmattan, Budapest, 2014

Tanulmánykötet. Terjedelem: 227. Bibliográfia a lábjegyzetekben.

ISBN 9789632368672

- A könyv a 2013 áprilisában, a Külföldi Magyar Kisebbségek Kutatóközpont (Research Institute for Hungarian Communities Abroad - NPKI) által szervezett Kisebbségek Európában: megoldások és kihívások címü konferenciájának a kötete. Az ott elhangzott előadások szerkesztett, angol nyelvű változatát olvashatjuk tíz tanulmányban. A tanulmányok fele általános és európai perspektívából tekint a kisebbségek helyzetére, míg a könyv másik fele kifejezetten a magyar közösségek autonómiaproblémáira fókuszál. A tanulmányok a kisebbségi lét számos aspektusára rávilágítanak. Olvashatunk arról, hogy az európai integráció vajon támo- 
gatja-e a kisebbségek autonómiatörekvéseit, hogy példaértékű lehet-e a dél-tiroli autonómia, vagy hogy jogi szempontból hogyan ítélhető meg a katalán függetlenségi törekvés. A romániai, szlovákiai és szerbiai magyar kisebbség helyzetével... is foglalkoznak tanulmányok. (Zs. V.)

- Alkotmányjogi alapismeretek: Magyarország alkotmányos intézményeinek vázlata Kiss Barnabás

(Sorozat: Pólay Elemér Alapítvány Tansegédletei; ISSN 1786-3554)

lurisperitus Pólay Elemér Alapítvány, Szeged, 2014

Tankönyv. Terjedelem: 180. Bibliográfia nincs. ISBN 9786155411120

- A szerző a Szegedi Tudományegyetem oktatója, akinek az alkotmányjogi jegyzete 2004 óta segíti a hallgatók felkészülését. Ahogy a címböl is következtethetünk rá, a könyv az alkotmányjog átfogó áttekintésére törekszik. Ennek megfelelöen külön fejezetekben tárgyalja a jogforrási rendszert, az emberi jogokat, a választási rendszert, az országgyülést, a köztársasági elnök intézményét, az Alkotmánybíróságot, az Állami Számvevőszék, a kormány, a helyi önkormányzatok és az igazságszolgáltatás működését. Az egyes témák után felkészülést segítő önellenőrző kérdések találhatóak. (Zs. V.)

- Police - minority relations: policing - ethnic minorities: restorative justice in police practice

Kozáry Andrea (szerk.)

L'Harmattan, Budapest, 2014

Konferenciakötet. Terjedelem: 140. Bibliográfia a lábjegyzetekben és a tanulmányok végén. ISBN 9789632369228

- A kötet szerkesztője a Nemzeti Közszolgálati Egyetem, a korábbi Rendőrtiszti Főiskola oktatója. A rendőrség és kisebbségek németországi, ausztriai és magyarországi konfliktusaival foglalkozó angol nyelvű könyv egy hároméves, 2012 januárja és 2014 decembere között futó európai uniós programot lezáró konferencia elöadásainak szerkesztett változatát tartalmazza. A tanulmányok szerzői között gyakorló rendöröket és egyetemi kutatókat is találunk, akik elemzik a török bevándorlók és a német rendőrség, az afrikai kisebbségek és az osztrák hatóságok, valamint a romák és magyar rendörök közötti problémákat, és az emberi jogok magas szintủ érvényesülését biztosító megoldási javaslatokat kínálnak, hogy a kisebbségek ne legyenek kitéve indokolatlan, kizárólag származásuk miatti rendőri intézkedéseknek. (Zs. V.)

- Magyarországot saját alkotmánya nélkül kormányozni nem lehet. A közjogász almanachja

KUKORELLI István

Méry Ratio, Budapest, 2014

Tanulmánykötet. Terjedelem: 415. Bibliográfia a lábjegyzetekben.

ISBN 9788081600364

- A tanulmánygyüjtemény szerzője egyetemi oktató, volt alkotmánybíró. A mủ egyes darabjai a 2011-es új Alaptörvényt közvetlen megelőző és azt követő években 
születtek. Az írások egy része könyvekben, kiadványokban, szaklapokban megjelent, másik része még nem publikált. A könyv három fejezetből áll. Az első fejezet a rendszerváltozásról, az 1989-es ideiglenes alkotmány születésének körülményeiről és annak további sorsáról szól. A második fejezet mérlegre helyezi az Alaptörvényt, megvizsgálja annak újításait, és összehasonlítja a régi alkotmánynyal. A harmadik fejezetben olvasmánynaplókat, könyvbemutatókat, opponensi véleményeket, laudációkat, emlékezéseket, beszédeket találunk. (Sz. Sz.)

- Romok ormán: Magyarország legújabb történetei

MAJTÉNYı László

Magvető, Budapest, 2014

Monográfia. Terjedelem: 479. Bibliográfia a lábjegyzetekben.

ISBN 9789631432244

- A szerző egyetemi oktató, az Eötvös Károly Közpolitikai Intézet elnöke. Művében a jogászi magyarázatok a köztársasági alkotmányról, valamint a helyébe lépő Alaptörvényről keverednek műelemzésekkel, szónoklatokkal, olvasói megjegyzésekkel vagy éppen kritikákkal szépirodalmi művekről. A szakszerü és a személyes hangvétel összemosódik, így a könyv nem csak a szük szakmai közönségnek szól. A kötetet alkotó írások bemutatják, hogyan is épültek föl a köztársaság intézményei, aztán hogyan rombolták le az ombudsmani intézményt, hogyan csorbították meg az Alkotmánybíróság hatásköreit, a polgárok petíciós lehetőségeit, hogyan veszítették el az emberi jogok elsődlegességüket, összefoglalva, a jogállamnak milyen veszteségekkel kell szembenéznie. Emellett központi szerepet kapott, hogy hogyan is élték meg e változásokat a magyar állampolgárok. (D. I.)

- Magyarország alkotmányjoga, I. kötet: Alapvetés, alkotmányos intézmények; Il. kötet: Államszervezet

Petrétel József

Második, javított, aktualizált kiadás. Kodifikátor, Pécs, 2014

Tankönyv. Terjedelem: 444; 419. Bibliográfia a fejezetek végén.

ISBN 978963899124 9; 9789638991249

- A szerző egyetemi oktató. A közelmúlt közjogi változásai - így az Alaptörvény és a hozzá kapcsolódó egyéb jogszabályok hatálybalépése - miatt szükségessé vált az alkotmányjogi tananyag átdolgozása, és az oktatást elősegítő, időszerü tankönyv elkészítése. Az első kötet az alkotmányjog alapjait tárgyalja, így az alkotmányjog jellemzőivel, az Alaptörvény jellegével, az alapelvekkel, a jogforrásokkal, az állampolgársággal, az országgyülési képviselők választásával, a helyi önkormányzati választásokkal, az országos népszavazással és a népi kezdeményezéssel, illetve a politikai pártokkal foglalkozik. A második kötet az Alaptörvény államszervezeti struktúrájának bemutatását és magyarázatát tüzte célul. Egy, az államszervezetet általánosságban jellemző fejezetet követően a főbb alkotmányos állami szervek - az Országgyülés, a köztársasági elnök, a Kormány, az Alkotmánybíróság és az alapvető jogok biztosa - ismertetése következik, önálló fejezetekben. Ezt követi a közpénzekre, a bíróságokra, az ügyészségre, a honvédségre és a rendőrségre vonatkozó szabályozás áttekintése. (B. É.) 
- Kézikönyv a német nemzetiségi önkormányzatok számára

Pfiszterer Angelika (szerk.)

Magyarországi Németek Országos Önkormányzata, Budapest, 2014

Kézikönyv. Terjedelem: 106. Bibliográfia nincs. ISBN nincs.

- A szerzők a Magyarországi Németek Országos Önkormányzatának munkatársai, a szerkesztő ezen önkormányzat kulturális referense. A kézikönyv rendszerezi a nemzetiségi törvény föbb rendelkezéseit, kiváltképpen az alapvető egyéni és közösségi nemzetiségi jogok és a nemzetiségi önkormányzat vonatkozásában. A nemzetiségek oktatási jogai, valamint a nemzetiségi önkormányzatok és a köznevelési rendszer szereplőinek együttmüködése is jellemzésre kerül. A kötet második része a nemzetiségi önkormányzatok gazdálkodása jogszabályi környezetének értelmezéséhez és a költségvetésre vonatkozó szabályok vizsgálatához ad magyarázatot. (R. A.)

\section{- A jogok törvénye: értekezés az alkotmányos szabadságról}

TÓтH Gábor Attila

(Sorozat: Dignitas luris, Debreceni Iskola; ISSN 2063-5087; 14.)

Gondolat, Budapest, 2014

Monográfia. Terjedelem: 295. Bibliográfia: 271-283. és a lábjegyzetekben. ISBN 9789636935382

- A szerző a Debreceni Egyetem oktatója, aki a modern alkotmányosság egy-egy témakörét járja körül kritikai olvasatban. Az első fejezet a jogi törvények jellemzöiröl szól, következtetése, hogy azok morális megfontolásoknak vannak alávetve. Az alkotmányról szóló második fejezet az alkotmányos demokrácia intézményrendszerét vizsgálja, kitérve a bizalom és bizalmatlanság szerepére az állam hatékony müködése tekintetében. A harmadik fejezet arra koncentrál, hogy miként befolyásolja az embrió jogi státusza az abortuszt és a reprodukciós orvoslást. A negyedik fejezet a személyi szabadság alapjogáról ad áttekintést. Az ötödik fejezet a gyülöletbeszéd problémájával foglalkozik. A szerző történeti és összehasonlító példák segítségével kétségbe vonja, hogy a szólás korlátozása hozzájárulna az állampolgári jogegyenlőség és a demokrácia fenntartásához. A hatodik fejezet egy esettanulmány a Schwimmer v. United States ügyröl. A zárófejezet az Alaptörvény utáni magyar alkotmányos realitást elemzi kritikusan, és szól a kilátásokról. (B. É.)

- Az alkotmányozás dilemmái: alkotmányos identitás és európai integráció

TRÓCSÁNYI László

HVG-ORAC, Budapest, 2014

Monográfia. Terjedelem: 277. Bibliográfia a lábjegyzetekben.

ISBN 9789632582269

- A szerző egyetemi oktató. Az Alaptörvény elfogadása heves szakmai vitákat váltott ki hazai és nemzetközi viszonylatban egyaránt. Az alkotmányozási eljárás és az új magyar alkotmány számos, sajátos rendelkezése vita tárgyát képezi az alkotmányjogászok között. A könyv ehhez a szakmai diskurzushoz járul hozzá. Célja, hogy a viták sarokpontjait bemutassa, és érzékeltesse, hogy a felmerült 
kérdésekre, problémákra más-más megközelítés alapján többféle válasz adható. A szerző elsőként a hagyományos alkotmányjogi fogalmak változásairól szól. Ezt követően a magyarországi alkotmányozást mutatja be, majd az Alaptörvény vitatott rendelkezéseit értékeli. Ezután az Alaptörvény és az alkotmányos identitás viszonyát értelmezi, majd az Európai Unió és az Európa Tanács szervei előtti magyar közjogi kérdéseket elemzi. A kötet végén mellékletként két, az Alaptörvényröl készült, egymással versengő vélemény található magyar fordításban. (B. É.)

- Alkotmányjog - alapjogok

Schanda Balázs-Balogh Zsolt (szerk.)

(Sorozat: A Pázmány Péter Katolikus Egyetem Jog- és Államtudományi Karának Tankönyvei, ISSN 2062-0837)

Második, átdolgozott kiadás, Pázmány Press, Budapest, 2014

Tankönyv. Terjedelem: 368. Bibliográfia a lábjegyzetekben.

ISBN 9789633081891

- A szerzők a Pázmány Péter Katolikus Egyetem Jog- és Államtudományi Karának oktatói. A könyv elsődlegesen azzal a céllal született meg, hogy könnyebbé tegye a joghallgatók elmélyülését az alapjogok területén, amelyet nem határterületnek, hanem az alkotmányjog lényegének tekint. Az első szerkezeti rész az emberi jogok eredetét, csoportosításait, alanyait és kötelezettjeit, az állam intézményvédelmi kötelezettségét, korlátozhatóságának kérdéseit és nemzetközi jogi szerepét mutatja be. A második szerkezeti egységben a hatályos jogszabályokhoz igazodva az egyes emberi jogok részletes elemzésére került sor. (D. I.)

- A demokrácia és a szólásszabadság határai: válogatott tanulmányok

SCHAUER, Frederick

CompLex, Budapest, 2014

Tanulmánykötet. Terjedelem: 650. Bibliográfia a lábjegyzetekben.

ISBN 9789632954479

- Frederick Schauer egyetemi oktató (University of Virginia, USA). A kötetbe Koltay András szerkesztő közremüködésével 26 tanulmányt választottak ki, amelyek eredetileg amerikai jogi folyóiratokban, illetve tanulmánykötetekben jelentek meg. A tanulmányok egyik nagy erénye, hogy bár Schauer jogi gondolkodása ízig-vérig amerikai, mégsem elutasító az európai jogi gondolkodással szemben. Nem zárkózik el attól, hogy az eltérő megközelítések közé hidat építsen; tanulmányaiban kérdez, javasol, polemizál. A kötet első szerkezeti egységében a szólásszabadság általános elméletével foglalkozó írások kaptak helyet. A másodikban az első alkotmánykiegészítés elméletét járja körül. A harmadikban a sajtó szabadságával, a negyedikben a szólásszabadság egyes részkérdéseivel foglalkozik. Az ötödik szerkezeti egység három összehasonlító szempontú tanulmányt tartalmaz, amelyekből jól kiolvasható, hogy a szerző kifejezetten az egyes országokban mérvadó sajátosságok értékessége mellett érvel. (D. I.) 
- Alkotmányjog I.: alkotmányos fogalmak és eljárások; Alkotmányjog II.: államszervezet

Smuk Péter (szerk.)

Universitas-Győr Nonprofit Kft, Győr, 2014

Egyetemi jegyzet. Terjedelem: 273; 242. Bibliográfia nincs.

ISBN 978615529831 8; 978615529842

- A szerkesztő és a szerzők egyaránt egyetemi oktatók. Az első kötet előbb az alkotmányjog különböző történeti fogalmaival ismerteti meg az olvasót, külön kitérve az alkotmányjog jogágiságának kérdésére. A továbbiakban az új Alaptörvény és a régi Alkotmány rendelkezéseinek különbségeit - különösen a demokratikus jogállam és hatalommegosztás vonatkozásában - részletezi, utalva az Alaptörvény alkotmányos patriotista jellegére. Az első kötet második fele a demokratikus legitimáció és népszuverenitás elveinek értelmezésével, majd a választójog témakörével foglalkozik. A második kötet Magyarország állam- és kormányformájának definiálásával kezdődik, egy kis kitérővel a történeti megoldásokra. Az Alaptörvényt és a vonatkozó jogszabályokat alapul véve jellemzi Magyarország alkotmányjogi berendezkedését, struktúráját. A föbb állami szervek bemutatása és átfogó magyarázata önálló fejezetekben történik. Különösen nagy hangsúlyt kap az igazságszolgáltatás történeti és jelenlegi szerepének vizsgálata. (R. A.)

- Kérdések az állami egyházjog köréböl: érintkezési pontok két önálló jogrendszer között

SzUROMI Szabolcs-FeRENCZY Rita

Szent István Társulat, Budapest, 2014

(Sorozat: Bibliotheca Instituti Postgradualis luris Canonici 3 Studia;

ISSN 1585-857X;17.)

Monográfia. Terjedelem: 195. Bibliográfia: 179-195. és a lábjegyzetekben.

ISBN 978963277419

- A szerzők a Pázmány Péter Katolikus Egyetem oktatói. A könyvben azon egyházjogi területek kerülnek bemutatásra, ahol a magyar jogszabályok és a katolikus egyház saját joga ugyanazon jogalanyok tevékenységét és jogcselekményeit szabályozza, nagyon gyakran egymástól lényegesen eltérő módon. A kötet egy 2002-ben kezdődő kutatásnak az eredményeit jeleníti meg, amelyet az állami és az egyházjog érintkezéseinek területein végeztek. Az elemzés nem tér ki minden egyes érintkezési terület részletes bemutatására, átfogó képet kíván nyújtani a magyar állami jogszabályok és a katolikus egyház önálló jogrendszerének egymáshoz való viszonyáról, a kánonjog jogi jellegéről, valamint a lelkiismereti és vallásszabadság Alaptörvényben rögzített érvényesülése biztosítékainak szükségességéröl. (D. I.)

- Alkotmányos alapismeretek: segédanyag az állampolgársági vizsgára készülő nem magyar állampolgárok számára a 2012. január 1-jén életbe lépett Alaptörvény szerint 
Tansegédlet. Terjedelem: 120. Bibliográfia nincs. ISBN 9789638920805

- A kilenc részből álló segédanyag az állampolgársági vizsgára készít fel. Ismerteti Magyarország fontosabb földrajzi, társadalmi adatait, nemzetközi kapcsolatait. Bemutatja az ország jelképeit és ünnepeit. Röviden összefoglalja hazánk történelmét, bemutatja a tudomány, a zene, a képzőmúvészet, az irodalom legfontosabb magyar képviselőit a különböző korszakokban. Ismerteti az Alaptörvényt és annak alapvető intézményeit, a közigazgatás felépítését, az alapvető állampolgári jogokat és kötelességeket, továbbá a magyar állampolgárság keletkezését, megszerzését, megszünését és igazolását. A kötet végén mellékletként megtalálható a Himnusz, a Szózat, a hungarikumok listája és az Európai Unió himnusza. (Sz. Sz.)

\section{BÜNTETŐJOG}

- Egység és halmazat - Régi dogmatikai kérdés, új megközelítésben AmBrus István

Szegedi Tudományegyetem Állam- és Jogtudományi Kar Büntetőjogi és Büntető Eljárásjogi Tanszék, Szeged, 2014

Tankönyv. Terjedelem: 316. Bibliográfia: 294-312. ISBN 9789633062654

- A szerző egyetemi oktató, ügyész, akinek kötete jelentős részben a Szegedi Tudományegyetemen 2012-ben megvédett, a büncselekményi egység hazai megítéléséről szóló PhD-dolgozatára épül. Művében Földvári József professzor 1962-es eredményeit veszi alapul, és ennek alapján veszi végig az egyes jogi problémákat. Egymást követően mutatja be a természetes egységet, a törvényi egységet, végül pedig a látszólagos halmazatot. Az egyes fejezetekben a fogalmi alapvetés és a jogtörténeti háttér ismertetése is megjelenik egy-egy dogmatikai kérdés kapcsán. A kötet a hazai felfogásokat is kellő részletességgel mutatja be. (A. Zs.)

\section{- Áldozatok és igazságszolgáltatás}

BARABÁs Andrea Tünde

Országos Kriminológiai Intézet, Budapest, 2014

Jegyzet. Terjedelem: 175. Bibliográfia: 132-142. ISBN 9789638946850

- A jegyzet szerzője jogász, kriminológus. A kötet a sértettek igazságszolgáltatásban elfoglalt helyét, szerepét vizsgálja. A hazai jogszabályok és a nemzetközi elvárások a valóságban nem érvényesülnek zökkenőmentesen. A kötet bemutatja az áldozattá válás legfontosabb kérdéseit, az ehhez kapcsolódó szakirodalmon túl az Országos Kriminológiai Intézet legújabb kutatásait és a vonatkozó szabályozásokat. Vázolja a viktimológia alapjait, az áldozatokra vonatkozó szabályokat a büntetőeljárásban, a bűnözéstöl való félelem kérdéskörét, a tömegkommunikáció hatásait, a diverzió új útját, a resztoratív igazságszolgáltatást, a mediációt Magyarországon és a büntetés-végrehajtásban alkalmazott helyreállító módszereket. A kötet segíti az olvasót a témakör jobb megértésében, de célja az is, hogy a jogalkalmazót hozzásegítse a sértettek méltányosabb kezeléséhez. (Sz. K.) 
- Tolvaj-kulcs. A betöréses lopások vizsgálata az elkövetök szemszögéböl Barabás A. Tünde (szerk.) Országos Kriminológiai Intézet, Budapest, 2014 Tanulmánykötet. Terjedelem: 188. Bibliográfia: 183-187. ISBN 9789638946874

- A kötet szerzői az Országos Kriminológiai Intézet tudományos fömunkatársai, továbbá pszichológusok, valamint az ELTE Pedagógiai és Pszichológiai Karának PhD-hallgatói. A könyv a büntetés-végrehajtási intézetben betöréses lopás miatt jogerősen elítélt fogvatartottak megkérdezésével készült empirikus kutatáson alapszik. A kutatás három részből állt: egy statisztikai elemzésböl, illetve az elítéltek között végzett képválasztós preferenciafelmérő és interjús vizsgálatokból. A tanulmánykötetben ennek eredményeiröl olvashatunk. A mü erénye, hogy olyan kutatást mutat be, amihez hasonló jellegü eddig nem készült Magyarországon, így nyújtva támpontot az áldozattá válás megelőzéséhez. (H. D.)

\section{- Büntetöjog I. Általános rész a 2012. évi C. törvény alapján}

Belovics Ervin-Nagy Ferenc-Tóth Mihály

Második, hatályosított kiadás. HVG-ORAC, Budapest, 2014

Tankönyv. Terjedelem: 556. Bibliográfia nincs. ISBN 9789632582528

- Tankönyv a joghallgatók és szakvizsgázók számára, és kézikönyv a hivatásos jogászoknak. A könyv szerzői az ország három jogi karán egyetemi tanárok, emellett gyakorlati szakemberek. A mủ megírását az új büntető törvénykönyv 2012-es elfogadása ösztönözte (az első, még négyszerzős kiadást a folyóirat 2014/1. számában annotáltuk). A könyv a Büntető Törvénykönyv Általános részét dolgozza fel mélyrehatóan. Bemutatja a történeti előzményeket, az egyes rendelkezések értelmezésére vonatkozó jogirodalmi álláspontokat. Vázolja a büntetőjog fogalmi rendjét, dogmatikai jellemzését, továbbá a kriminológiai célkitüzések érdekében tett lépéseket, illetve azok korlátait. Elemzi a nemzetközi és a magyar büntetőjogi intézményrendszerek összefüggéseit, rávilágít a felmerülő jogharmonizációs igényekre. Az elméleti elemzés mellett az olvasó megismerheti az irányadó joggyakorlatot. Megkönnyíti a szövegben történő eligazodást a könyv elején található jelmagyarázat, ami segít az adott szövegrészek mellett elhelyezkedő szimbólumok értelmezésében. (G. Á.)

- A büntetö hatalom korlátainak megtartása: a büntetés mint végső eszköz - tanulmányok Gönczöl Katalin tiszteletére

Borbíró Andrea-Inzelt Éva-Kerezsi Klára-Lévay Miklós-Podoletz Léna (szerk.)

ELTE Eötvös Kiadó, Budapest, 2014

Tanulmánykötet. Terjedelem: 499. Bibliográfia a lábjegyzetekben.

ISBN 9789632845111

- Az ünnepelt egyetemi tanár, kriminológus, a szerzők egyetemi oktatók és gyakorló jogászok. A negyvenkét szerző harminckilenc tanulmánya közt jogi és egyéb, társadalomtudományi (például szociológiai) munkákat is találunk. A tanulmányok a büntetést mint végső eszközt különböző nézőpontokból mutatják be. Többek között feldolgozták a Btk.-ban megjelenő jogállami garanciákat, a gyülölet-bűncselekmények hatékony üldözésének feltételrendszerét, az antiszemitizmust a 
mai Magyarországon, és találunk tanulmányt a fiatalok bűnelkövetéséről, az USAban történt iskolai és campuserőszakról, a büntetőeljárásról, illetve az áldozatok fogalmáról és jogairól az Európai Unióban. Bemutatásra kerülnek még többek közt a romákkal kapcsolatos elöítélek, az elmúlt száz év hazai börtönügye és a büntetőjog új tendenciái. (Sz. K.)

- Magyar büntetőjog - Különös rész

Csemáné VÁradi Erika-Gilányı Eszter-Görgényı Ilona-Gula József-Jacsó JuditLÉVAY Miklós-SÁNTHA Ferenc

Miskolci Egyetemi Kiadó, Miskolc, 2014

Egyetemi jegyzet. Terjedelem: 210. Bibliográfia nincs. ISBN 9786155216671

- A Miskolci Egyetem Állam- és Jogtudományi Karának jegyzete elsősorban az igazságügyi igazgatás alapszak hallgatóinak készült. A szak sajátosságaihoz igazodva nem a büntetőjogi különös rész teljes körü ismertetésére törekszik, hanem azt a szak által megkívánt részletességgel mutatja be. A jegyzet szerkezete az új Btk. Különös részének felépítéséhez igazodik: fejezetenként ismerteti azt. A törvényszövegből idézve mutatja be az egyes tényállásokat, azt követően magyarázza azokat, és leírja a szükséges ismereteket. A szerkezet logikailag jól tagolt. A jegyzet erőssége, hogy az általános megértéshez, kellő átlátáshoz szükséges mértékben, tárgyilagosan és egyszerüen fogalmazva mutatja be a büncselekményeket. (A. Zs.)

- Veszélyes fiatalok vagy fiatalok veszélyben?

Czenczer Orsolya

NKE Szolgáltató Kft., Budapest, 2014

Monográfia. Terjedelem: 194. Bibliográfia: 164-173. ISBN 9786155527043

- A szerző a Nemzeti Közszolgálati Egyetem oktatója. Olyan fiatalkorú elkövetőkkel foglalkozik, akik nehéz körülmények között nőttek fel, környezetükben gyakori volt a szülői bünelkövetés és a bántalmazás is. A fiatalkorú elkövetőkkel való bánásmód kiemelkedő jelentőségü, mivel személyiségük még alakítható, nevelhető, így az eltérítés a fiatalkorú elkövetők tekintetében kitüntetett szereppel bír. A monográfia arra is keresi a választ, hogy milyen szerepe lehet a büntetés-végrehajtásnak a fiatalkorú elkövetök tekintetében. A fiatalkorú elkövetők kriminalizálásával kapcsolatos kérdéseket jár körül, illetve a fiatalkorúak büntető igazságszolgáltatásban elfoglalt specifikus helyzetét kutatja. (Sz. K.)

\section{- Az új Btk. és a kapcsolódó jogforrások, bírósági iránymutatások}

Czine Ágnes (szerk.)

HVG-ORAC, Budapest, 2014

Kézikönyv. Terjedelem: 605. Bibliográfia nincs. ISBN 9789632582184

- A könyv az új Büntető Törvénykönyv értelmezéséhez nyújt segítséget. A kötet vázát a Btk. normaszövege adja, melynek rendelkezéseihez a szerkesztő hozzárendeli a törvény indokolásának vonatkozó tartalmát, az Alaptörvény egyes cikkeinek, a háttérjogszabályoknak és az Európai Unió jogának kapcsolódó rendelkezéseit. A könyv tartalmazza a törvény egyes rendelkezéseihez tartozó jogértelmezési 
kérdéseket is, ezen belül az Alkotmánybíróság vonatkozó határozatait, a Kúria, illetve jogelődje, a Legfelsőbb Bíróság kapcsolódó jogegységi határozatait és BK véleményeit. A könyv végén a közzétett elvi határozatok és eseti döntések találhatóak. A fent vázolt rendszerben történő eligazodást a könyv elején ismertetett szimbólumok, illetve a könyv végén található két mutató könnyíti meg. Az egyik mutató az új Btk. szakaszai szerinti keresést segíti, a másik pedig a Kúria idézett testületi döntéseinek elöfordulását rögzíti. A szerkesztő a könyvet a tárgyalóteremben gyakran megforduló, illetve szakvizsgára készülő jogászoknak ajánlja. (G. Á.)

- Büntető anyagi jog II. és IV. az új Btk. alapján

Deres Petronella-Domokos Andrea

Patrocinium, Budapest, 2014

Egyetemi jegyzet. Terjedelem: 114 és 89. Bibliográfia nincs. ISBN 978615533757 4; 9786155337642

- A szerzők a Károli Gáspár Református Egyetem Állam- és Jogtudományi Kar Büntetőjogi, Büntető Eljárásjogi és Büntetés-végrehajtási Jogi Tanszék oktatói. A II. számú könyv az egyetemen oktatott Büntetőjog II. című tantárgy tematikáját követi, a hallgatók számára készült segédanyag. A szerzők az új Btk. általános részében szabályozott jogintézményeket elemeznek, a kötetben a büntető törvénykönyv VII-XI. fejezetében található rendelkezéseket mutatják be. A tananyagot vázlatosan tartalmazó írás tartalmazza a vonatkozó $A B$ határozatokat és $B K$ véleményeket is. $A I V$. könyv a Büntetöjog IV. címü tantárgy tematikáját követi. A szerzők az új Btk. XXVI-XXIX., XXX., XXXIV-XVI., XXXIX., XL., XLI. fejezeteihez tartozó büncselekmények körébe tartozó tényállásokat elemeznek. A tényállásvázlatokat, illetve kapcsolódó gyakorlati példákat tartalmazó írás minden joghallgató számára kiváló segítséget nyújt a tananyag elsajátításához. (G. Á.)

- Gyakorlókönyv a Btk. általános részéhez

Fantoly Zsanett-Karsal Krisztina-Szomora Zsolt

lurisperitus Bt., Szeged, 2014

Egyetemi jegyzet. Terjedelem: 163. Bibliográfia nincs. ISBN 9786155411076

- A szerzők a Szegedi Tudományegyetem Állam- és Jogtudományai Kar Büntetőjogi és Büntető Eljárásjogi Tanszékének oktatói. A könyv a joghallgatók büntetöjogi tanulmányaihoz nyújt segítséget. Három részben tartalmaz feladatokat, amelyek az egész általános részi tananyagot lefedik. Az első részben az elméleti feladatok találhatóak, amelyek az általános összefüggések megértését és a pontos jogi terminológia elsajátítását szolgálják. A második rész a jogesetek gyüjteménye, amely hozzájárul a kritikus gondolkodás fejlesztéséhez. A harmadik rész pedig tíz tansegédletet tartalmaz, köztük táblázatokkal, az egyes kérdések vizsgálatát szemléltető folyamatábrákkal és leírásokkal. (G. Á.)

- Gyakorlókönyv a Btk. különös részéhez I-II. kötet 
Egyetemi jegyzet. Terjedelem: 174; 183. Bibliográfia nincs. ISBN 9786155411113 ; 9786155411069

- A szerzők a Szegedi Tudományegyetem Állam- és Jogtudományai Kar Büntetőjogi és Büntető Eljárásjogi Tanszékének oktatói. A kétkötetes könyv a büntetőjogot tanuló joghallgatók különös részi tanulmányaihoz nyújt segítséget. A gyakorlókönyvek elsősorban jogeseteket, illetve néhány elméleti feladatot tartalmaznak. A jogesetek összeállításánál a szerzők a Bírósági Határozatokban közzétett döntések történeti tényállásait vették alapul. A könyvek az egyedi döntéseket az oktatási szempontoknak megfelelően átalakítva tartalmazzák. Egyes gyakorlatokhoz megoldókulcs is található a kötetekben. Az első kötet a Btk. XV-XXIV. fejezeteiben szabályozott tényállásokkal kapcsolatos feladatokat tartalmazza, míg a második a XXVII-XLIII. fejezeteiben található tényállásokhoz kapcsolódóakat. (G. Á.)

- Rendészetelmélet

FinszTER Géza

NKE Szolgáltató Kft., Budapest, 2014

Tankönyv. Terjedelem: 275. Bibliográfia: 268-275. és a lábjegyzetekben. ISBN 9786155305597

- A szerző a rendészettudomány és a kriminalisztika szakértője, egyetem oktató. A tankönyv célja, hogy a közigazgatási, katonai és rendészeti képzési terület alap-, illetve mesterszakok és ezekhez kapcsolódó doktori programok résztvevőinek gyakorlatban használható tudást adjon. Feldolgozza a megváltozott közjogi struktúrát, közvetíti a legújabb szaktudományos eredményeket, emellett találunk a müben nemzetközi kitekintést is. Tárgyalásra kerülnek a rendészet tudományelméleti alapjai, illetve társadalmi rendeltetése. A jogi normákon túl hétköznapi tapasztalatokra, szakmai ismeretekre és tudományos kutatások eredményeire is támaszkodik a szerző. (Sz. K.)

- Rendészettudományi gondolatok. Írások a Magyar Rendészettudományi Társaság megalapításának egy évtizedes jubileuma alkalmából

Gaál Gyula-Hautzinger Zoltán (szerk.)

Magyar Rendészettudományi Társaság, Budapest, 2014

Tanulmánykötet. Terjedelem: 225. Bibliográfia az egyes tanulmányok végén és a lábjegyzetekben. ISBN 9786155305511

- A kötet szerzői között egyetemi oktatókat, kutatókat, rendőröket és gyakorló jogászokat is találunk. A mü három nagyobb részböl áll, melyek a rendészet és rendészettudomány, a rendészet határterületei, valamint a rendészettudomány szervezése és évtizedes története kérdéseit vizsgálják. Ezen belül írások születtek a társadalomtudományok és a rendészet kapcsolatáról, a rendészettudomány helyéről, szerepéröl, jövőjéröl, és nem utolsósorban a Magyar Rendészettudományi Társaság évtizedes történetéröl. (H. D.)

- Bejelentés vagy feljelentés? A pénzmosás és a terrorizmus finanszírozása elleni küzdelemmel kapcsolatos feladatok és kötelezettségek az új Büntetö Törvénykönyv alapján 
GÁL István László

Második kiadás. Penta Unió, Budapest, 2014

Monográfia. Terjedelem: 206. Bibliográfia a lábjegyzetekben.

ISBN 9786155249068

- A könyv a 2013-as, második kiadás változatlan utánnyomása; 2015/2. számunkban annotáltuk. (G. Á.)

\section{- Magyar Büntetőjog - Általános Rész}

GörgénYI llona-Gula József-Horváth Tibor-Jacsó Judit-LévaY Miklós-SántHa Ferenc-VÁRADI Erika

CompLex, Budapest, 2014

Tankönyv. Terjedelem: 564. Bibliográfia: 559-564. ISBN 9789632954394

- A kötet a Miskolci Egyetem Állam- és Jogtudományi Karának Büntetőjogi és Kriminológiai Tanszéke által korábban közreadott a „Magyar Büntetőjog - Általános rész" címü a 2012. évi C. törvény elfogadását követően közreadott tankönyv átdolgozása. Jelen kiadás a jogszabályi változások és a szakmai tapasztalatok figyelembevételével készült, elsősorban joghallgatók számára, azonban a szerzők joggal ajánlják gyakorló jogászoknak is. A tankönyv követi a Büntető Törvénykönyv Általános Rész szerkezetét, figyelemmel a magyar és az európai büntetöjog-tudomány fejlödésére. Ismerteti a vonatkozó bírói gyakorlatot a kúriai és az alkotmánybírósági jogesetek feldolgozásán keresztül. (G. Á.)

- Az EU mint a szabadság, a biztonság és a jog térsége. Magyarország az Európai Unióban, 2004-2014

Hollán Miklós (szerk.)

Nemzeti Közszolgálati Egyetem Nemzetközi Intézet, Budapest, 2014

Szakkönyv. Terjedelem: 227. Bibliográfia a lábjegyzetekben és a fejezetek végén. ISBN 9786155491399

- A szerzők egyetemi oktatók, helyettes államtitkárok. A könyv célja, hogy bemutassa a büntetőjogot érintő európai uniós joganyagot és annak hazai implementációját. Az egyes fejezetek előbb röviden bemutatják a történeti fejlődést, majd az adott terület hatályos szabályozását. A fejezetek végén a szabályozás továbbfejlesztésére vonatkozó hivatalos javaslatok bemutatása áll. A mủ alkalmas mind a felsőoktatásban, mind a közszolgálati továbbképzésben való használatra, továbbá a gyakorlati szakemberek számára is segítséget nyújthat. (H. D.)

- Korrupciós büncselekmények az új büntetökódexben

Hollán Miklós

HVG-ORAC, Budapest, 2014

Monográfia. Terjedelem: 194. Bibliográfia: 181-191. ISBN 9789632582566

- A szerző tudományos kutató, egyetemi oktató. A könyv célja a korrupciós büncselekményekkel kapcsolatos hazai jogszabályok, joggyakorlat, illetve a jogirodalmi álláspontok részletes feldolgozása, a 2012. évi C. törvény rendelkezései alapján. A könyvben olvasható a jelenleg hatályos Btk. és az 1978. évi Btk. rendelkezéseinek az összevetése is. Itt azt vizsgálja a szerző, hogy a korábbi szabályozás- 
sal kapcsolatos felsőbírósági iránymutatások és eseti döntések mennyire tarthatók fent az új büntetőkódex alkalmazása során. A szerző olyan problémákra is igyekszik megoldást találni, amelyek felmerülése a joggyakorlatban ma még csak várható, illetve a hatályos szabályozás kiigazítására vonatkozó, de lege ferenda javaslatokat is megfogalmaz. A szerző a müvét elsősorban azoknak a bíráknak, ügyészeknek, ügyvédeknek és rendőröknek ajánlja, akik napi munkájuk során szembesülnek a korrupciós büncselekményekre vonatkozó új rendelkezések alkalmazásával. (G. Á.)

- Közigazgatási büntetőjog

Jacsó Judit-SÁnTHA Ferenc

Miskolci Egyetemi Kiadó, Miskolc, 2014

Jegyzet. Terjedelem:158. Bibliográfia: 157-158. ISBN 9786155216343

- A 2012-es kiadás változatlan, második utánnyomása. A könyv előző kiadásához 2014/1. számunkban közöltünk leírást. (Sz. K.)

- Beyond Punitiveness: Crime and Crime Control in Europe in a Comparative Perspective

Kiss Valéria (szerk.)

(Sorozat: Proceedings of Criminology; ISSN 0236-9893; 73.)

Magyar Kriminológiai Társaság, Budapest, 2014

Konferenciakiadvány. Terjedelem: 134. Bibliográfia a fejezetek végén.

ISBN 9789630897044

- A szerzők magyar és külföldi tudományos szakemberek New York, Leeds, Tübingen és San Bernardino egyetemeiröl, a Lengyel és a Magyar Tudományos Akadémiáról, valamint az ELTE-ről. Az angol nyelvű könyv a 2013. szeptember 4-7. között, az ELTE Kriminológiai Tanszékének és a Magyar Kriminológiai Társaságnak szervezésében megrendezésre került, azonos címú konferenciáján elhangzott előadások válogatását tartalmazza. A kötetben szereplő írások a bủncselekmények, a kriminológia és az állami büntetőpolitika viszonyára, kulturális hátterére, a hazai kriminálpolitika egyes fejlődési szakaszaira és jelenlegi kihívásaira fókuszálnak. (H. D.)

- Sport és büntetőjog

NAGY Zoltán András

Kódex Nyomda Kft., Pécs, 2014

Monográfia. Terjedelem: 232. Bibliográfia: 230-232. ISBN 9786155290053

- A szerző a Pécsi Tudományegyetem Állam- és Jogtudományi Karának oktatója, aki a sporthoz - a versenysporthoz és az amatőr sporthoz is - kapcsolódó büntetőjogi kérdéseket fejti ki részletesen. A könyv kitér a dopping elleni küzdelemre, továbbá elemzi az autó-motor sportok és a kerékpárversenyek biztonsága körében felmerülő szabálysértéseket és bűncselekményeket, a hirtelen szívhalál felelősségi kérdéseit, emellett körbejárja a zaklatás, a verbális és a fizikai erőszak kérdéskörét. A könyv ismerteti a sport területén előforduló vesztegetést, a sportfogadási csalást, valamint az illegális szerencsejáték-szervezést. A szerző ír a sportegye- 
sületek gazdálkodásával összefüggő visszaélésekröl, az állatokkal szemben elkövetett bűncselekményekröl, illetve a sportpályán előforduló szeméremsértést is érinti. A könyvben ismertetett érdekes jogeseteken keresztül még könnyebben értelmezhetőek a leírtak. (G. Á.)

- Magyar büntetöjog - Különös rész Nagy Zoltán-Tóth Mihály (szerk.)

Osiris, Budapest, 2014 Tankönyv. Terjedelem: 609. Bibliográfia: 607-609. ISBN 9789632761923

- A szerzők egyetemi oktatók, céljuk a hallgatói igényeknek megfelelően, logikus rendszerben tagolt oktatási segédanyag készítése volt. A könyv megalkotásának apropója az új Büntetö Törvénykönyv megszületése. A Magyarország negyedik Büntető Törvénykönyvének megismerését, a jogalkotói szándék megértését segítő tankönyv a különös részi fejezeteket, azaz a Btk. XIII. fejezetétől a XLIV. fejezetéig terjedő részét tárgyalja. Az egyes tényállások részletes bemutatását csak esetenként mellőzik a szerzők, de ilyenkor is összefoglalják a büncselekmények legfontosabb ismérveit. Az új és újszerü tényállások elemzése a pécsi büntetőjogi iskola hagyományait követi. (Sz. K.)

- A fiatalkorú bünözés kriminológiája és szociológiája

Rosta Andrea

L'Harmattan-Uránia Ismeretterjesztő Alapítvány, Budapest, 2014

Tankönyv. Terjedelem: 399. Bibliográfia nincs. ISBN 9786155436055

- A szociológus végzettségű szerző a Pázmány Péter Katolikus Egyetem oktatója. A könyv a fiatalkorú bűnözést mutatja be átfogóan, és rávilágít arra, hogy ezen jelenség megértéséhez nem elég csupán a jogi oldalról történő megközelítés. A szerző ismerteti a müben a fiatalkorú bűnözés kriminológiai, szociológiai, pszichológiai, statisztikai és büntetőjogi aspektusait, emellett pedig bemutatja a kapcsolódó alapvető nemzetközi dokumentumokat is. Betekintést nyerhetünk a fiatalkorúak által elkövetett büncselekményekbe, és a mögöttük meghúzódó okokba. A szerző leírja a fiatalkorú bủnelkövetők lehetséges útját az igazságszolgáltatás világában. A szerző a könyvet elsősorban a szociológiai, kriminológiai és jogi oktatásban látja hasznosíthatónak, azonban a bírák, ügyészek, ügyvédek, pártfogók, rendőrök, nevelötisztek, illetve a bünmegelőzés, családsegítés és a gyermeknevelés területén tevékenykedő szakemberek mindennapi munkájához is segítségül szolgálhat. (G. Á.)

- Tendenciák és alapvetések a bünügyi tudományok köréböl

Ruzsonyi Péter-Balláné Füszter Erzsébet (szerk.)

NKE Szolgáltató Kft., Budapest, 2014

Tanulmánykötet. Terjedelem: 391. Bibliográfia a tanulmányok végén és a lábjegyzetekben. ISBN 9786155491337

- A tanulmánykötet szerzői túlnyomóan egyetemi oktatók. Munkájuk elsősorban a bünügyi tudományok iránt elkötelezett doktori hallgatóknak szóló szakkönyv, melyben megtalálhatóak a szükebb szakterületek alapvetései és a legújabb ten- 
denciák leírása. A kötetben feldolgozásra kerültek a következő területek: az állami büntetőhatalom érvényesülése, a büntetőjog fejlődése, a magyar büntetőeljárás, az uniós bünügyi együttmüködés. A kötet képet ad a közigazgatási tilalmakról és a rendészeti szolgálatban megjelenő bírságokról, pönológiai alapvetésekről, büntetés-végrehajtás jogi szabályozásáról, bemutatja a külföldiekre vonatkozó büntetőjogi szabályozás rendszerét, a kriminálgeográfiát, és a tudomány szerepét a nyomozásban. (Sz. K.)

\section{EURÓPA-JOG ÉS NEMZETKÖZI JOG}

- A Nemzetközi Büntetőbíróság joghatósága. Előzmények, tendenciák és előfeltételek

ÁdÁNY Tamás Vince

(Sorozat: A Pázmány Péter Katolikus Egyetem Jog- és Államtudományi Karának Könyvei - Doktori Értekezések; ISSN 2064-1907)

Pázmány Press, Budapest, 2014

Monográfia. Terjedelem: 272. Bibliográfia: 249-272. és a lábjegyzetekben. ISBN 9789633081822

- A szerző egyetemi oktató, nemzetközi jogász, a monográfia a 2011-ben megvédett PhD-értekezése alapján készült. A nemzetközi büntetőjog egy részterületét öleli fel a kötet: az egyéni felelősség alkalmazhatóságának nemzetközi jogi kereteit elemzi. A könyv első részében a téma történeti előzményeit vizsgálja, különös tekintettel a II. világháború után felállított törvényszékekre, valamint a nemzetközi büntetőjog nemzeti fórumokon történő alkalmazásának akadályaira. A monográfia második része a nemzetközi büntetőjog aktuális kérdéseivel foglalkozik, mindenekelőtt a Nemzetközi Büntetőbíróság eljárásával, annak anyagi jogi és eljárásjogi előfeltételeit vizsgálja, különös tekintettel az egyéni felelősségre vonás kérdésére. (P. N.)

- Nemzetközi szervezetek és intézmények

BlaHó András-PRANDler Árpád

(Sorozat: Nemzetközi Gazdaság Szakkönyvtár; ISSN 2061-1050)

Akadémiai Kiadó, Budapest, 2014

Tankönyv. Terjedelem: 616. Bibliográfia: 607-616. és a lábjegyzetekben.

ISBN 9789630595278

- A szerzők egyetemi oktatók; Blahó András nemzetközi és uniós gazdaságtannal foglalkozó közgazdász, Prandler Árpád 2014-ben bekövetkező haláláig a hágai székhelyű jugoszláv ad hoc törvényszék ad litem bírája. A könyv a 2011-es kiadás alapján készült (korábbi kiadásai egy másik kiadónál jelentek meg 2001-től), s a teljesség igényével veszi végig a nemzetközi szervezetekre vonatkozó tudnivalókat általában és az egyes konkrét nemzetközi szervezetek vonatkozásában is. A könyv a történeti előzményektől kezdve a jelenben történő kihívásokig olyan globális és regionális nemzetközi szervezetek részletes bemutatását vállalja, mint az ENSZ, a NATO, az EU vagy az Európa Tanács. Egyes fejezeteken belül a 
szervezetek elözményeit, intézményeit és a keretükben kidolgozott nemzetközi szerződéseket mutatja be. Az egyik legjobban sikerült és alapvető fontosságú kézikönyv a nemzetközi szervezetek müködése iránt érdeklődők számára. (K. Zs.)

- Integrálódó Európa I. - szerződések, folyamatok, intézmények Ferkelt Balázs-Káldyné Esze Magdolna-KruPPa Éva-Vida Krisztina Harmadik, átdolgozott és bővített kiadás. Perfekt, Debrecen, 2014 Tankönyv. Terjedelem: 302. Bibliográfia: 296-302. ISBN 9789633948408

- A kötet elsősorban az európai integrációval kapcsolatos alapismereteket tartalmazza. A szerzők igyekeztek a felsőoktatásban kialakult tantárgyi struktúrákhoz igazítani a szerkezetet. Külön fejezetben tárgyalják az integráció elméleti és jogi alapjait, történeti előzményeit, valamint elmélyülését és kibővülését. A könyv az Unió intézményi és döntéshozatali rendszere mellett magában foglalja a jogrendszer és tagállamok jogharmonizációs kötelezettségének témakörét is. A belső piac jellemzésén túl kitér az Unió politikáira is, így a közös kereskedelempolitika, versenypolitika, közös agrárpolitika, kohéziós politika fejlődésére, szabályozási keretére. A gazdasági és monetáris unió, valamint az Unió költségvetése szintén külön fejezetben kap helyet. Mindezen tárgyköröket a szerzők az egymásra épülő, alapító és módosító szerződések rendszerén keresztül mutatják be. Kiegészítve a korábbi kiadást, a mellékletben az Európai Unióval kapcsolatos legfontosabb gazdasági, kereskedelmi adatokat is tartalmazza a kötet. (Be. A.)

- Bevezetés az Európai Unió jogába

GREKSZA Veronika-MoHAY Ágoston

IDR Publikon, Pécs, 2014

Egyetemi jegyzet. Terjedelem: 106. Bibliográfia: 102. ISBN 9786155457272

- A szerzők a Pécsi Tudományegyetem oktatói. A kötet rendkívül hasznos a jogi aszszisztensek oktatása során, valamint más (nem jogász) szakok hallgatói számára is, akik az Európai Unió integrációtörténetével, intézményrendszerével és jogi alapjaival ismerkednek meg. A könyv kilenc fejezetben mutatja be az Európai Unió fejlődéstörténetét, intézményrendszerét, tevékenységi területeit és az uniós polgárság intézményét, külön kiemelve a fontosabb fogalmakat és jogeseteket. Hangsúlyozottan „bevezetés”, és nem a jogászképzésben használt tankönyv. (P. N.)

\section{- Európai és nemzetközi médiajog}

KeLLER, Perry

Wolters Kluwer, Budapest, 2014

Monográfia. Terjedelem: 628. Bibliográfia: 613-628. és a lábjegyzetekben. ISBN 9789632954097

- A szerző emberi jogokkal és médiajoggal is foglalkozó nemzetközi jogász. A mü egyediségét az adja, hogy a kulturálisan, földrajzilag és nyelvileg is eltérő nemzeti médiaszabályozás tekintetében egy globálisan érvényes, közös szabályozás alapját kívánja lefektetni. A kötet alapvető kérdése: feloldható-e a szabályozások közötti ellentét? Ezzel kapcsolatos kiindulópontnak a liberális demokráciafelfogást választotta, melynek révén - a szólásszabadságra kiemelkedő hangsúlyt fektetve 
- fejezetröl fejezetre vizsgálja meg azt, hogy hogyan viszonyul maga a liberális demokrácia a médiához. (K. Zs.)

\section{- International protection of human rights}

LatTMAnN Tamás-Tóth Norbert-Vızı Balázs

Nemzeti Közszolgálati Egyetem, Budapest, 2014

Egyetemi jegyzet. Terjedelem: 144. Bibliográfia nincs. ISBN 9786155491429

- A szerzők nemzetközi jogászok, oktatók. A könyv egy sorozat része, a „Tudásalapú közszolgálati előmenetel" nevű projekt keretein belül született meg. Célja, hogy az alap- és mesterképzésben részt vevő, valamint a PhD-programot kezdö, az állami szolgálatok mellett elkötelezett hallgatók tudását új tantervi kereteken belül fejlesszék tovább. A könyv amellett, hogy általánosságban is kitér az emberi jogok nemzetközi védelmének bemutatására, számba veszi az ENSZ égisze alatt müködő emberi jogi szervezeteket és dokumentumokat is. A kötet továbbá - a szerzők kutatási területeit alapul véve - egy-egy fejezet erejéig részletesebben kitér a kisebbségek védelmére, valamint a háborús összeütközések során meglévő emberi jogokra. (K. Zs.)

\section{- Uniós szakpolitikák}

Szabó Marcel-Láncos Petra Lea-Gyeney Laura (szerk.) Harmadik kiadás. Szent István Társulat, Budapest, 2014 Tanulmánykötet. Terjedelem: 260. Bibliográfia a lábjegyzetekben. ISBN 9789632774602

- A szerzők Európa-joggal foglalkozó jogászok, egyetemi oktatók. A kötet két bevezető írást követően, melyek az Európai Unió jogi természetével és az európai közigazgatás rendszerével foglalkoznak, négy témakör alá csoportosítva tárgyalja az Európai Unió szakpolitikáit. Az Unió alkotmányos jellegü politikái körében a vallás, a nyelv, a család és az Európa-jog kérdéseivel foglalkozó tanulmányok találhatóak. A szabályozó jellegű politikák között a közös kereskedelempolitika, versenypolitika, tudománypolitika, egészségügyi politika és menekültpolitika témájában született tanulmányok kaptak helyet. Az elosztó jellegü politikák sorában a mezőgazdasági, az újraelosztó politikák között pedig a fejlesztési és strukturális politika aktuális kérdéseit elemzik a szerzők. A kötet hasznos lehet az uniós szakpolitikák iránt érdeklődő kutatók, szakemberek és hallgatók számára is. Előző kiadását 2015/2. számunkban ismertettük. (P. N.)

\section{- Essential EU Law in Charts}

Tobler, Christa-Beglinger, Jacques

Harmadik, aktualizált, átdolgozott kiadás. HVG-ORAC, Budapest, 2014

Tansegédlet. Terjedelem: 376. Bibliográfia nincs. ISBN 9789632582412

- A leideni (Hollandia) és a bázeli (Svájc) egyetem professzoraként, illetve Zürichben (Svájc) praktizáló ügyvéd szerzők munkája a közös tankönyvüknek immár harmadik, ún. „Lisszabon-kiadása”. Az előző kiadásokhoz hasonlóan azzal a céllal született, hogy az Európai Unió jogrendszerének vizuális megjelenítésével (szerkezeti és folyamatábrákon keresztül történő szemléltetésével) segítse 
elsajátítani annak sajátos, számos tekintetben bonyolult rendszerét. 283 ábrájuk - utalással a releváns európai bírósági jogesetekre - az Unió jogrendszerével kapcsolatos kérdéseket az integráció fejlődése, az intézmények rendszere, az EU hatáskörei, a másodlagos jogalkotás, a belső piac, a versenyjog és az uniós jog kikényszerítése kapcsán ismerteti. Az előző kiadás annotációja a 2013/2. lapszámban szerepel. (Be. A.)

- Essential EU Law in Text

Tobler, Christa-Beglinger, Jacques

HVG-ORAC, Budapest, 2014

Egyetemi jegyzet. Terjedelem: 122. Bibliográfia nincs. ISBN 9789632582405

- A könyv az azonos szerzőktől származó „Essential EU Law in Charts” társkötete. A két mű együttes célja, hogy segítse a gyakorlati szakemberek és a joghallgatók európai uniós ismereteinek elmélyítését, különös tekintettel a Lisszaboni Szerződés és az általa előidézett alapvető változtatásokra az EU jogrendszerét illetően. A mű külön fejezetben tárgyalja az EU jogi alapjait az integráció elörehaladása alapján, kiemelve a jogrendszer sajátos természetét. Szintén külön fejezetben vizsgálja a belső piac és a versenyjog szabályait, a szociális jogot, külön kitér az integráció mélyítésének eszközeire, mind az elsődleges, mind a másodlagos jogi aktusok alapján. Az utolsó fejezet az uniós jog kikényszerítésének eszközeit mutatja be. (Be. A.)

\section{JOGTÖRTÉNET, RÓMAI JOG}

- A Szegedi Királyi Ítélótábla története 1890-1914 között - Fejezetek a Szegedi Ítélötábla történetéből I.

ANTAL Tamás

(Sorozat: Bíróságtörténeti Könyvek; ISSN 2064-9533)

Országos Bírósági Hivatal-Szegedi Ítélőtábla, Budapest-Szeged, 2014

Monográfia. Terjedelem: 167. Bibliográfia: 129-143. ISBN 9789631208856

- A szerző a Szegedi Tudományegyetem oktatója, maga a kötet pedig egy sorozat első része, amely átfogó képet ad a Szegedi Királyi İtélőtábla történetéről annak megalakulásától kezdve 1914-ig bezárólag. A szerző részletes adatokkal alátámasztva eleveníti fel az ítélötáblák létrehozásának körülményeit, elsősorban kihegyezve azt Szeged városára. A levéltári adatok alapján pontos képet kapunk a korszakról, magáról a bíróságról és annak szervezetéről is, mindenekelőtt azonban az új szerv létrehozásának nehézségeivel szembesülhetünk. A könyv második nagy szerkezeti egységében megtalálhatjuk az ítélőtábla bíráinak archontológiáját, a megjelölt időszakban hozott döntvényeket és a jegyzőkönyveket, melyek kiváló adatokat szolgáltatnak a téma iránt érdeklődők számára. A mü végén rövid angol nyelvü összefoglaló is helyet kapott. (Sz. Zsa.) 
- Alapfogalmak a római magánjog köréböl; Alapfogalmak a római vagyonjog köréböl CsOKnya Tünde Éva-Jusztinger János-PókEcz Kovács Attila (Sorozat: Publicationes Cathedrae luris Romani Quinqueecclesiensis; ISSN 20647328; 2, 1.)

PTE-ÁJK Római Jogi Tanszék-Dialóg Campus, Pécs, 2014

Egyetemi jegyzet. Terjedelem: 121; 87. Bibliográfia nincs. ISBN 978963642644 6; 9789636426378

- A szerzők a Pécsi Tudományegyetem Római Jogi Tanszékének oktatói. A két kötet a szerzők saját bevallása szerint nem tekinthető sem önálló tankönyvnek, sem a római jogi alapfogalmak széles körét bemutató enciklopédikus feldolgozásnak, de hasznos segítséget jelenthet a tananyag értelmezéséhez. A mü a teljesség igénye nélkül a tananyag részét képező egyes jogintézmények pontos tartalmának meghatározását célozza. Önálló fejezetekben tárgyalja a római jog forrásai, a perjog, a családjog, a dologi jog, a kötelmi jog és az öröklési jog legfontosabb római jogi fogalmait. (D. V.)

- Válogatás a modern magyar honvéd-katonai büntető joghistória forrásaiból, 1867-1945, I. és II. kötet

Farkas Ádám (szerk.)

Magyar Katonai Jogi és Hadijogi Társaság, Széchenyi István Egyetem Batthyány Lajos Szakkollégium, Győr, 2014

Dokumentumgyűjtemény. Terjedelem: 377; 464. Bibliográfia: 366-376, 452-463. ISBN 978963089566 8; 9789630895675

- A kötet szerkesztője a Széchenyi István Egyetem oktatója. A gyüjtemény célja, hogy a korabeli katonai büntetőjog, illetve katonai büntetőeljárás és katonai büntető igazságszolgáltatás iránt érdeklődők számára kiindulási alapot biztosítson azáltal, hogy összegyűjti az 1867 és 1945 között hatályban volt katonai büntető jogszabályokat és háttérjoganyagokat (például császári nyílt parancsokat, miniszteri körrendeleteket). A bevezető tanulmányt, mintegy 120 dokumentumot és forrásjegyzéket tartalmazó kötet hiánypótlónak tekinthető, hiszen a jogásztársadalomnak is csak „gyenge fogalmai” vannak a korabeli katonai büntetőjogról. (D. V.)

- A magyar jog fejödésének fél évezrede - Werbőczy és a Hármaskönyv 500 esztendő múltán

Máthé Gábor (szerk.)

Nemzeti Közszolgálati Egyetem, Budapest, 2014

Tanulmánykötet. Terjedelem: 446. Bibliográfia a lábjegyzetekben. ISBN 9786155344572

- A szerzők egyetemi oktatók, gyakorló jogászok és történészek. A tanulmánykötet A magyar jogfejlődés fél évezrede címü tudományos konferencia anyagát tartalmazza, mely konferenciát a Tripartitum megszületésének 500. évfordulójának alkalmából tartották a Nemzeti Közszolgálati Egyetem és az MTA IX. osztály Állam- és Jogtudományi Bizottságának szervezésében. A tanulmánykötetben 19 önálló tanulmány található, melyek a konferencia szekcióülései szerint vannak fejezetekre osztva. Olyan fontos tárgyköröket érintenek, mint Werbőczy István 
életútjának egyes állomásai, a Hármaskönyv összevetése az európai kodifikációs folyamatokkal, több tanulmány keretében is vizsgálják a mü hatásait a későbbi jogalkotásban, illetve magának a Hármaskönyvnek a felépítése, annak az egyes rendelkezései is vizsgálat alá kerülnek. A tanulmányok bőséges lábjegyzetei kiváló kiindulópontként szolgálhatnak a további kutatásokhoz, valamint minden egyes tanulmány angol és német nyelvü rövid összegzése is fellelhetö. (Sz. Zsa.)

- Kolozsvári boszorkányperek 1564-1743

Pakó László-Tóth G. Péter (szerk.)

(Sorozat: A magyarországi boszorkányság forrásai; ISSN 1589-6080; 4.)

Balassi, Budapest, 2014

Forráskiadvány. Terjedelem: 427. Bibliográfia: 423-427. ISBN 9789635069309

- A mű egy több évtizede tartó, a boszorkányüldözéssel kapcsolatos források felkutatását célzó OTKA-kutatás keretében született, az eddigiek - Nagybánya, Segesvár, Sopron - mellett immáron Kolozsvár városának boszorkánypereit mutatják be a 16-18. századból. A mü levéltári kutatáson alapszik, és bár elsősorban Komáromy Andor, Kiss András és Pakó Pál munkásságára épít, az általuk feldolgozott eseteket már kiegészítve, javítva, rendszerezve, teljes terjedelemben mutatja be. Összesen 88 per anyagát olvashatjuk, váltakozva magyar és latin nyelven. Az egyes ügyek iratanyagának terjedelme meglehetősen változó; a fennmaradt források változatosságának köszönhetően néhol részletes tanúvallomások, ítéletek, máshol pedig csak néhány bejegyzés olvasható. A célirányos keresést a mủ végén található részletes név- és helymutató segíti. (Sz. Zsa.)

- Ernyedetlen szorgalommal... A Debreceni Tudományegyetem jogász professzorai (1914-1949)

P. Szabó Béla (szerk.)

(Sorozat: Historia Facultatis luridicae IV.)

Debreceni Egyetem Állam- és Jogtudományi Kara, Debrecen, 2014

Emlékkönyv. Terjedelem: 688. Bibliográfia a lábjegyzetekben.

ISBN 9789634737490

- A szerzők a Debreceni Egyetem Állam- és Jogtudományi Karának oktatói. A kötet harminc olyan jogászprofesszor életútját és munkásságát mutatja be, akik az egykori Debreceni Tudományegyetemen részt vettek a jogi oktatásban. A kötet nem tekinthető minden elözmény nélkülinek, hiszen 2002-ben, 2004-ben és 2006ban is jelent meg egy-egy kötet azon professzorok és magántanárok életútjáról, akik rövidebb-hosszabb ideig szereplői voltak a debreceni jogi képzésnek. Minden fejezet egy-egy jogászprofesszort mutat be, azonos szempontok szerint. A tanulmányok egyenként feldolgozzák a professzorok életrajzát, bemutatják és értékelik munkásságukat, végül pontos, teljességre törekvő bibliográfiát nyújtanak a professzori életmúvekröl. A kötet az egyetemi szintű debreceni jogászképzés centenáriumára készült. (D. V.) 
- Universitas „unius rei” - Tanulmányok a római jog és továbbélése köréből

P. Szabó Béla-Újvári Emese (szerk.)

DE Marton Géza Állam és Jogtudományi Doktori Iskola, Debrecen, 2014

Tanulmánykötet. Terjedelem: 350. Bibliográfia a lábjegyzetekben.

ISBN 9789634737070

- A tanulmányok szerzői egyetemi oktatók. A kötetben 15 különálló tanulmány olvasható, melyek a Debreceni Egyetem Állam- és Jogtudományi Karán megrendezett magyar római jogászok Universitas „unius rei” címü konferenciáján hangoztak el. A tanulmányok többsége magyar nyelvű, de megtalálható benne egy-egy német, angol és francia nyelvü tanulmány is, illetve minden egyes tanulmány rövid idegen nyelvű összefoglalója is. A szerzők számos témakört érintenek; többek között olvashatunk a természetjogról, szakrális szabályokról, raktárházak jogállásáról, a semmisségről és a megtámadhatóságról, de olyan írások is színesítik a tanulmánykötetet, melyek a gazdasági és hitelválság római jogi megoldásait, vagy az első magyar római jogi monográfiát kutatják. A tanulmánykötet tehát valóban komplex ismeretanyagot tartalmaz a római jog és továbbélése köréből, mely tanulmányokat a bőséges lábjegyzet és forrásmegjelölés teszi igazán színvonalassá. (Sz. Zsa.)

- A bizalmi vagyonkezelés és a trust: jogtörténeti és összehasonlító jogi elemzés SÁNDOR István

HVG-ORAC, Budapest, 2014

Monográfia. Terjedelem: 489. Bibliográfia: 419-452. ISBN 9789632582191

- A szerző egyetemi oktató és gyakorló ügyvéd. Új kötetének célja elsősorban az angolszász eredetű trust jogi természetének bemutatása. Ennek során ismerteti a trust kialakulását, angol szabályozását, az átvétel problematikáját, de kitér a trusthoz hasonló jogi konstrukciók bemutatására is, európai, ázsiai, afrikai és amerikai országok jogrendszereinek vizsgálatán keresztül. A szerző egy fejezetet az új Ptk. hatálybalépésével a magyar jogba bekerülő bizalmi vagyonkezelés intézményének a bemutatására is szánt. A kötet logikus felépítésü, bőséges felhasznált irodalom alapján készült, több mint kétezer lábjegyzet teszi hitelessé a benne szereplő adatokat. (D. V.)

- Házassági akadályok a bizánci akatolikus egyházak jogrendjében és alkalmazásuk a katolikus gyakorlatban

SzotYoRI-Nagy Ágnes

(Sorozat: Bibliotheca Instituti Postgradualis Iuris Canonici Universitatis Catholicae de Petro Pázmány Nominatae IV., Dissertationes; ISSN 1586-0957; 10.)

Szent István Társulat, Budapest, 2014

Monográfia. Terjedelem: 292. Bibliográfia: 271-292. ISBN 9789632774787

- A szerző a Pázmány Péter Katolikus Egyetem oktatója. Jelen kötet a 2009-ben írott doktori disszertációja nyomán, a „Tehetségtámogatás a Pázmány Péter Katolikus Egyetem kilenc tudományágában" címü TÁMOP-projekt keretében jelent meg. Az öt nagy fejezetre tagolódó mủ az ortodox egyházak bemutatásával kezdődik, majd a keleti akatolikus egyházakra alkalmazott jogrenddel ismerteti meg 
az olvasót. Ezt követően két fejezetben tárgyalja a bizánci házasságjog forrásait és annak fogalmát, majd az utolsó, ötödik fejezetben kitér a címben is megjelölt házassági akadályokra. A mű gazdag forrásanyaga miatt nemcsak érdekes, de hasznos olvasmány is a kánonjog iránt érdeklődők számára. ( $D . V$.)

- A nádori intézmény korai története 1000-1342

Szücs Tibor

(Sorozat: Subsidia ad historiam medii aevi Hungariae inquirendam; ISSN 1787-9213; 5.)

MTA Támogatott Kutatócsoportok Irodája, Budapest, 2014

Monográfia. Terjedelem: 331. Bibliográfia: 277-298. ISBN 9789635086979

- A szerző történész, könyve alapjául a Szegedi Tudományegyetemen 2013-ban megvédett doktori értekezése szolgált. A kutatás és a téma alapját az Árpád-korból származó nádori oklevelek adják, melyek a szerző által már korábban kiadásra kerültek. (Az Árpád-kori nádorok és helyetteseik okleveleinek kritikai jegyzéke, szerk. Szőcs Tibor, Bp., 2012.) Jelen munkájában tehát a korhű források alapján elemzi a nádori intézmény történetét az Árpád-korban, leírja az intézmény létrejöttét, a nádor hatásköreit, különös figyelmet szentelve a nádor bírói hatáskörére, ahol nemcsak a feladatait és az alá tartozó népelemeket veszi sorba, hanem az egyik bíróságot, a generalis congregatiót is részletesen bemutatja. A mü végén függelékként a korábbi könyvéből kimaradt nádori okleveleket is megtalálhatjuk. (Sz. Zsa.)

\section{KÖRNYEZETJOG}

- Környezetjog

BándI Gyula

Második, átdolgozott kiadás. Szent István Társulat, Budapest, 2014

Tankönyv. Terjedelem: 501. Bibliográfia: 501. és a lábjegyzetekben.

ISBN 9789632775050

- A szerző egyetemi tanár, kötete a 2011-es kiadás átdolgozásán alapul (a korábbi kiadás annotációját lásd a Pro Futuro 2013/1. számában). A hazai jogászképzésben klasszikusnak számító szerkezetben a nemzetközi jogi, illetve az európai uniós követelmények, valamint a szabályozási struktúrák játsszák a föszerepet, ennek megfelelően a tananyagot a jogszabályok gyakori változásai nem érintik érzékenyen. A mostani változtatásokat különösen az új Alaptörvény, a környezetvédelmi igazgatási szervezet átalakulása és egyes ágazati törvények (például hulladéktörvény) megjelenése indokolták. (B. Á.)

- Energiajog az ökológiai fenntarthatóság szolgálatában

BÁnYal Orsolya

DELA, Debrecen, 2014

Monográfia. Terjedelem: 275. Bibliográfia: 252-265. és a lábjegyzetekben. ISBN 9789634737520 
- A szerző a Debreceni Egyetem oktatója, aki - 2013-ban megvédett doktori diszszertációja átdolgozásával - az energiajog anyagi jogi részének a feldolgozására vállalkozott. A kötet elsősorban a klímapolitikához kapcsolódó energetikai szakterületeket (például energiatakarékosság, megújuló energiák) veszi sorra, s elemzi az ökológiai fenntarthatóságnak - a szerző által külön értelmezett - nézőpontjából. A feldolgozás az ökológia, a közgazdaságtan és a jogtudomány eredményeire épül, ugyanakkor az energiapolitikai dokumentumok, a nemzetközi jogi, európai uniós és magyar energiajogi normák rendkívül széles körét illetően úttörőnek tekinthető. A szakterületet a közigazgatási jogi megközelítés hagyományosan leszükített közegéből tematikailag és módszertani szempontból is kiragadva értékel, és fejlesztési irányokat jelöl ki. lly módon elkerülve a tételes jogi elemzések tipikus csapdáit, közelebb hozza a komplex témakörhöz mind a jogász, mind a közgazdász vagy természettudós olvasót. (F. L.)

- Környezetvédelmi termékdij. A gyakorlati szakemberek termékdij kódexe

BARTos Gyula-DebreczenI László-Kovács Csaba

e-Termékdíj.hu Kft., Budapest, 2014

Kézikönyv. Terjedelem: 261. ISBN 9789630885256

- Mindhárom szerző gyakorlati szakember, akik testközelböl ismerik a termékdíj szabályozásának minden elméleti és gyakorlati vonatkozását. A környezetvédelmi termékdíj szabályozása hazánkban 1995-töl eredeztethető. Az eltelt évek alatt sokszor változott, de alapvető lényegét, a környezet védelmét a jogalkotó sosem tévesztette szem elöl. A jogszabály a gazdasági szabályozóeszközök kategóriájába sorolható, de nem elsősorban adójogszabály, hanem olyan pénzügyi kötelezettségeket is keletkeztető normarendszer, amely a gazdaság szereplői számára különböző díffizetési kötelezettségeket és tevékenységeket ír elö. A szakkönyv a termékdíjjal és a hulladékgazdálkodás kapcsolódó területeivel foglalkozó gazdasági szakembereknek, felsőfokú tanulmányaikat végző hallgatóknak és minden környezetgazdasági szabályozás iránt érdeklődőnek ajánlható. (L. N.)

- Környezet, jog, gazdaságtan: környezetpolitikai eszközök, környezet-gazdaságtani modellek és joggazdaságtani magyarázatok

BARTus Gábor-Szalal Ákos

(Sorozat: Jogtudományi Monográfiák; ISSN 2061-5191; 6.)

Pázmány Press, Budapest, 2014

Tankönyv. Terjedelem: 375. Bibliográfia a fejezetek végén. ISBN 9789633082058

- A szerzők egyetemi oktatók. A kötet (mely az interneten is teljes terjedelmében elérhető) a környezeti probléma és a közgazdasági elméleti háttér bemutatásával kezdődik. Ezt a környezetpolitikai eszközök általános kérdései (melyek elemzése során a szerzők egyforma jelentőséget tulajdonítanak Pigou és Coase tételének), valamint az egyes szabályozó eszközök (magánjogi eszközök, közvetlen elöírások és gazdasági ösztönzők) részletes ismertetése, elemzése és nem utolsósorban egymáshoz való viszonyának bemutatása követi. Végezetül a természeti eröforrások optimális kitermelése és a fenntarthatóság értelmezése képezik a vizsgálat tárgyát. A könyvet a szerzők nemcsak a közgazdász-, hanem a jogász- és 
a mérnökhallgatók számára készítették, megértését mindenekelőtt nagyszámú ábra, táblázat és példa segíti elő. (B. Á.)

- Földjogi szabályozások Bobvos Pál-Hegyes Péter JATEPress, Szeged, 2014. Egyetemi jegyzet. Terjedelem: 173. Bibliográfia nincs. ISBN 9789633151808

- A szerzők egyetemi oktatók. Jegyzetükböl a földforgalmi szabályozás története után megismerkedhetünk a föld tulajdonjogának szerzésével a földforgalmi törvény alapján, majd a föld hasznosításával, használatával foglalkoznak a szerzők, mielött bemutatnák a mezőgazdasági üzemet. Említésre kerül a Nemzeti Földalap, az erdő-, vad- és borgazdálkodás, végül pedig a hegyközségek szabályozása. A jegyzet az agrárjog könnyebb elsajátítása végett született meg, de csak a tananyag egy részét tartalmazza.. Nem kínál elméleti rendszert, mert ahhoz egész területek szabályozása hiányzik még. (L. N.)

- Környezetjogi szabályozások

FaRkas Csamangó Erika

JATEPress, Szeged, 2014

Egyetemi jegyzet. Terjedelem: 264. Bibliográfia: 261-264. ISBN 9789633152027

- A szerző egyetemi oktató. A könyv célja a környezeti szabályozás legfontosabb kérdéseinek bemutatása, a szabályozás és a végrehajtás lehetséges rendszerének felvázolása. A környezeti alapvetések után az általános majd különös részt ismerhetjük meg, végül a környezetért való felelősségröl olvashatunk. A jegyzet összeállításával a szerzőt kifejezetten az a cél vezérelte, hogy segítséget nyújtson a joghallgatóknak a hatályos joganyag alapvető rendelkezéseinek elsajátításához. (L. N.)

- Klímavédelem az energiajogban - szabályozási modellek Németországból Fodor László CompLex Wolters Kluwer, Budapest, 2014 Monográfia. Terjedelem: 218. Bibliográfia: 203-218. és a lábjegyzetekben. ISBN 9789632954493

- A szerző egyetemi oktató. A könyv hiánypótló abból a szempontból, hogy a környezeti energiajognak (Umweltenergierecht) keresztelt jogterület néhány szegmensét mutatja be az egyre terjedelmesebb német szakirodalom feldolgozásán keresztül. A munka bevallottan nem törekszik teljességre, megelégszik néhány szakterület (például a megújuló energiaforrások támogatása a villamosenergia-ágazatban; az atomenergia szabályozásának a környezetvédelmi szempontból hangsúlyos elemei; a német atomstop alkotmányjogi kérdései; kibocsátáskereskedelem; energiatárolás, a szén-dioxid leválasztása és tárolása; hálózatfejlesztés stb.) részleges leírásával. A szerző a német központi szabályozás ismertetésére helyezi a legnagyobb hangsúlyt, de a könyv utolsó fejezetében a helyi önkormányzatoknak az energiafordulatban betöltött szerepével is foglalkozik. A könyvet elsősorban azoknak ajánljuk, akiknek már van egy bizonyos szintű rálátásuk az energiajognak e sajátos területére. (B. O.) 
- Környezetjog

FODOR László

Debreceni Egyetemi Kiadó, Debrecen, 2014

Tankönyv. Terjedelem: 317. Bibliográfia: a lábjegyzetekben és 307-317. ISBN 9789633184059

- A szerző a Debreceni Egyetem tanára. A kötet elsősorban joghallgatók számára készült, és a környezetjog, valamint az agrárkörnyezetjog címü tárgy témaköreinek elsajátítását segíti elő. Az elméleti megalapozás körében a szabályozási tárggyal, a környezetjog rendszerével, forrásaival és szabályozási módszertanával foglalkozik. Az általános részben a környezetvédelmi szabályozás kialakításának szempontjai, alkotmányjogi alapjai, az állami szervezetrendszer vázlata, továbbá egyes jogintézmények (például engedélyezés, hatásvizsgálati típusok) találhatóak. A különös részi témakörök tekintetében a földre, a vízre, a levegőre és klímára, a hulladékra és a természet védelmére vonatkozó speciális előírásokkal ismerkedhet meg az olvasó. A tananyag elsajátítását áttekinthető szerkesztés, kiemelések és (apró betűs) háttérinformációk segítik. A témában való további eligazodást a kötet végén elhelyezett bőséges szakirodalmi jegyzék támogatja. (Gy. A. Cs.)

- Környezetbiztonság

HaLÁsz László-FöLDI László

NKE Hadtudományi és Honvédtisztképző Kar, Budapest, 2014

Egyetemi jegyzet. Terjedelem: 141. Bibliográfia: 139-141. ISBN 9786155305979

- A szerzők a Nemzeti Közszolgálati Egyetem oktatói. A környezetbiztonság egyrészt a környezeti elemek biztonságos használatát, másrészt az azokkal való célszerű gazdálkodást jelenti. Jelen könyv e koncepcióból kiindulva tekinti át a környezetvédelem föbb területeit (levegőtisztaság-, víz-, talajvédelem, hulladékgazdálkodás, zaj- és rezgésvédelem), valamint a környezetbiztonságot veszélyeztető hiányokat (energiaellátási problémák, vízhiány stb.), és eligazítást ad a környezetbiztonság tervezésére, megvalósítására vonatkozóan. (L. N.)

- Fenntartható energetika megújuló energiaforrások optimalizált integrálásával Kalmár Ferenc (szerk.)

Akadémiai Kiadó, Budapest, 2014

Tanulmánykötet. Terjedelem: 403. Bibliográfia a fejezetek végén. ISBN 9789630595407

- A kiadvány a Debreceni Egyetemen müködő DEnzero című, interdiszciplináris alapkutatási projekt eredményeit tartalmazza. A szerzők több tudományterület oktatói, kutatói, így a kötetben energetikai, energiahatékonysági, valamint elméleti és gyakorlati elemzéssel foglalkozó fejezetekkel is találkozunk. A környezetjogi fejezet szerzői a Debreceni Egyetem oktatói, akik az ökológiai fenntarthatóságot szolgáló energiajog áttekintésére vállalkoztak. Az általános elméleti kérdéseken túl speciális szabályozási területek, jogintézmények áttekintésével találkozik itt az olvasó, olykor nemcsak az európai uniós, hanem a tagállami szabályozási színtereket is érintve. (Gy. A. Cs.) 
- A környezetvédelmi jog alapjai

OrLovits Zsolt-CsEgöDi Tibor László

Negyedik, javított kiadás. Szent István Egyetemi Kiadó, Gödöllő, 2014

Egyetemi jegyzet. Terjedelem: 232. Bibliográfia nincs. ISBN nincs.

- A szerzők egyetemi oktatók. Jegyzetük a környezetjog általános és különös részét is feldolgozza, a környezetvédelmi mérnökképzés igényeinek megfelelően. Egyik érdekessége, hogy a környezetvédelmi szabályozás történetének bemutatását Kr. e. 5000-től kezdi. A környezetjog legalapvetőbb jogintézményeit egyéni, a jogászképzésben használt tankönyvektől eltérő struktúrában mutatja be; tárgykörei például a környezetvédelmi szakigazgatás, a környezetvédelmi urbanisztika, az egyes környezeti elemek védelme, a géntechnológia és a globális problémák. (L. N.)

- Környezettudatos energiatermelés és -felhasználás III.

Szabó Valéria-Fazekas István (szerk.)

MTA DAB Megújuló Energetikai Munkabizottsága, Debrecen, 2014

Tanulmánykötet. Terjedelem: 265. Bibliográfia a tanulmányok végén.

ISBN 9789637064319

- A szerzők határon túli és hazai oktatók, kutatók; a kötet a 2014-ben rendezett Környezet és Energia Konferencián elhangzott előadásokhoz kapcsolódó tanulmányokat tartalmazza. A környezeti, energetikai és klímavédelmi szempontú írások között három tanulmány foglalkozik jogi kérdésekkel. Ezek az Európai Unió klímavédelmi, azon belül is a teherelosztási szabályozásának egyes kérdéseit, az EU 2012/27/EU számú energiahatékonysági irányelvét, valamint a megújuló energiahordozókból előállított villamos energia támogatására szolgáló, kötelező átvételi rendszert mutatják be. (Gy. A. Cs.)

\section{KÖZIGAZGATÁSI JOG}

- Helyi önkormányzatok

Árva Zsuzsanna-BALÁzs István-BARTA Attila-VeszPRÉmı Bernadett Harmadik, átdolgozott kiadás. Debreceni Egyetemi Kiadó, Debrecen, 2014 Tankönyv. Terjedelem: 274. Bibliográfia a lábjegyzetekben és az egyes fejezetek végén. ISBN 9789633184585

- A szerzők a Debreceni Egyetem jogi karának oktatói, akik a jogi szabályozás változásait figyelembe véve az előző kiadáshoz képest hatályosították a tankönyvet (lezárása 2014. október 31.; az előző kiadás annotációját lásd a folyóirat 2012/1. számában), illetve - a pénzügyi jog körébe való tartozására tekintettel - elhagyták belőle a helyi önkormányzatok vagyonát és gazdálkodását tárgyaló fejezetet. A tankönyv jól áttekinthető felépítése (sokszor a legfontosabb ismeretek felsorolásba rendezése), nyelvezete megkönnyíti az egyetemi hallgatók számára a helyi önkormányzatokkal kapcsolatos valamennyi közigazgatási jogi témakört felölelő tananyag elsajátítását. (P. O.) 
- Magyar közigazgatási jog. Általános rész 1-2.

Árva Zsuzsanna-BalÁzs István-BARTA Attila-Veszprémı Bernadett

Második, átdolgozott kiadás. Debreceni Egyetemi Kiadó, Debrecen, 2014

Tankönyv. Terjedelem: 291; 245. Bibliográfia a lábjegyzetekben.

ISBN 978963318456 1; 9789633184578

- A szerzők a Debreceni Egyetem jogi karának oktatói, akik a jogi szabályozás változásait figyelembe véve az előző kiadáshoz képest hatályosították a tankönyvet (lezárása 2014. október 31.; az előző kiadás ismertetését lásd a 2015/1. számunkban), illetve - a pénzügyi jog körébe való tartozására tekintettel - elhagyták belőle a helyi önkormányzatok vagyonát és gazdálkodását tárgyaló fejezetet. Az első kötet a közigazgatás és a közigazgatási jog fogalmán, sajátosságain túl az intézményrendszerrel, illetve a személyzettel foglalkozik. A második kötetet új fejezettel bővítették a szerzők, mely a jó állam és közigazgatás fogalmával, a közigazgatás változásainak új irányaival és prioritásaival foglalkozik. Itt ezenkívül a hatósági jogalkalmazás, a közigazgatási aktusok, a közigazgatási hatósági eljárás, a szabálysértési jog, az elektronikus közigazgatás témaköre kapott helyet. A szerzők az oktatási célokra is tekintettel (jól érthető, átlátható szerkezetű, a képzés tematikájához illeszkedő, kiemelésekkel, illetve ábrákkal is szemléltetett tartalommal) járják körbe az egyes eljárásjogi intézményeket. (P. O.)

- Közigazgatási jog. Különös rész l-Il.

Bencsik András (szerk.)

(Sorozat: Institutiones Juris, ISSN 1218-9375, Dialóg Campus Tankönyvek, ISSN 1418-1274)

Második, bővített kiadás. Dialóg Campus, Budapest-Pécs, 2014

Tankönyv. Terjedelem: 183; 159. Bibliográfia a lábjegyzetekben és az egyes fejezetek végén. ISBN 9786155376146

- A 2012-ben kiadott tankönyv (amelyet a folyóirat 2014/2. számában annotáltunk) bővített változata. Szerkesztője és a szerzők is egyetemi oktatók. Az első kötet a közigazgatási jog különös részének fogalmát és jelentőségét tárgyaló bevezetést követően egyrészt a gazdasági igazgatás egyes területeivel, másrészt a humán közszolgáltatások igazgatása köréből az állami alapnyilvántartásokkal, a szociális igazgatással, az egészségügy, illetve a felsőoktatás igazgatásával foglalkozik. A második kötet a védelmi igazgatást, valamint a humán közszolgáltatások igazgatásának az első kötetben foglaltakon túli témaköreit tárgyalja, nevezetesen a kulturális, a köznevelésügyi, a gyermekvédelmi és gyámügyi igazgatást. A tankönyv célja - az egyes témák rövid elméleti megalapozásának és fejlődéstörténetének bemutatásán túl - elsősorban a 2014 őszén hatályos jogi szabályozás feldolgozása az oktatási szempontok figyelembevételével. Szerkezete könnyen átlátható, a hallgatók számára a tanulást kiemelések segítik. (P. O.) 
- A szabálysértési törvény magyarázata: [a 2014. július 1-jéig hatályba lépett módositásokkal]

BIsZTRICZKı László-KánTÁs Péter

HVG-ORAC, Budapest, 2014

Kommentár. Terjedelem: 809. Bibliográfia a lábjegyzetekben.

ISBN 9789632582375

- A szerzők egyetemi oktatók és gyakorlati szakemberek. A kommentár célja az, hogy bemutassa a 2012. április 15-én hatályba lépett, új szabálysértési törvény sarkalatos változásait, felvillantva ezáltal, hogy a jogalkotó egy gyorsabb eljárás kialakítását kívánta elérni, szigorúbb szankcionálással. Szerkezete jól követi a szabálysértési törvény felépítését. Bemutatásra kerülnek az általános ismeretek, a szabálysértési eljárás, a végrehajtás, a nyilvántartási rendszer és az egyes szabálysértések tipizálása. A szerzők osztják azt a felfogást, hogy a szankciórendszer szigorítása csupán a latenciát fokozza, önmagában azonban nem elégséges eszköze a bünmegelőzésnek. A könyvet haszonnal forgathatják az egyetemi hallgatók és gyakorlati szakemberek egyaránt. (K. K. E.)

- A fenntartható közigazgatás elmélete

Bukovics István

Nemzeti Közszolgálati és Tankönyv Kiadó, Budapest, 2014

Kézikönyv. Terjedelem: 238. Bibliográfia: 237-238. ISBN 9786155305320

- A szerző egyetemi oktató. A könyv célja a közigazgatással kapcsolatos ismeretek tudományos szemléletű bemutatása, a közigazgatás-tudomány alapjainak ismertetése. A kiadvány a ,jobb megértés” célzatával igyekszik minél több logikailag igazolható tudományos következtetést levonni az elöre rögzített alapfeltevésekből. Az elemzés kiindulási alapjául a közigazgatás és a biztonság fenntarthatósága szolgál, melyet a funkciók fenntartásának premisszájával köt össze. A mú ennek a szemléletnek a teljes körü bemutatása, melyhez a sajátos „katasztrófaelmélet" módszerét használja. (K. B.)

- Alternatív (?) média - A közösségi média jogi szabályozásának vetületei GoszTONYI Gergely

ELTE Eötvös Kiadó, Budapest, 2014

Kézikönyv. Terjedelem: 262. Bibliográfia: 233-253. ISBN 9789633121948

- A szerző egyetemi oktató. A könyv célja az alternatív média definiálása és kategorizálása, melynek keretében részletes ismertetést ad az alternatív média történetéröl mind nemzetközi, mind hazai vonatkozásban, valamint meghatározza annak helyét az Európai Unió jogrendszerében. A szerző a továbbiakban vizsgálja a hatályos magyar médiaszabályozást, kitérve a vitás kérdésekre, a közösségi médiaszolgáltatókra, valamint a közösségi médiaszolgáltatók és a Nemzeti Média- és Hírközlési Hatóság sajátos helyzetére. Ezen túlmenően a mű előretekintően vizsgálja a médiatörvény-tervezetek közösségi médiára vonatkozó szabályozását. (K. B.) 
- Közös jogkezelés az audiovizuális médiában

GRAD-GYEnge Anikó-SARKADY Ildikó

(Sorozat: Médiatudományi Könyvtár; ISSN 2063-5222; 10.)

Médiatudományi Intézet, 2014

Kézikönyv. Terjedelem: 168. Bibliográfia nincs. ISBN 9786155302060

- A szerzők egyetemi oktatók és gyakorló jogászok. Művük célja a közös jogkezelés kialakulásának bemutatása, a definíciók és a rendszertani alapvetések meghatározása. A könyv a fentiek mellett a közös jogkezelés uniós és nemzetközi jogi beágyazottságával és szabályozásával, a jelenlegi ellentmondásos helyzetek létrejöttével, valamint a hazai közös jogkezelés kialakulásának történetével is foglalkozik. A mü utolsó része az érintett terület jövőjére reflektál, az európai szabályozási mechanizmus tükrében. (K. B.)

- A rendészeti szervek vezetés- és szervezéselmélete Horváth József-Kovács Gábor (szerk.)

Nemzeti Közszolgálati Egyetem, Közigazgatás-tudományi Kar, Budapest, 2014 Tankönyv. Terjedelem: 240. Bibliográfia a fejezetek végén. ISBN 9786155305412

- A könyv elméleti és gyakorlati szakemberek munkája, annak a 16 kötetből álló tankönyvsorozatnak a része, amelynek célja a közigazgatási, katonai, illetve rendészeti képzésben részt vevők számára a legfrissebb ismeretek átadása. A tananyag homlokterében, címének megfelelően, a rendészeti szervek vezetésével és szervezésével összefüggő kérdések állnak. Ehhez igazodva a kötet elején a vezetés- és szervezéselmélet általános fogalmai és intézményei kerülnek bemutatásra, míg a második rész az egyes rendészeti szakágak, például rendőrség, büntetés-végrehajtás, katasztrófavédelem felsőszintű irányításának elveit és specifikumait ismerteti, ábrákkal és táblázatokkal kiegészítve. (B. A.)

- Hatékony közszolgálat és jó közigazgatás: nemzetközi és európai dimenziók Kaiser Tamás (szerk.)

Nemzeti Közszolgálati Egyetem, Budapest, 2014

Tanulmánykötet. Terjedelem: 191. Bibliográfia: 189-191. és a fejezetek végén. ISBN 9786155491375

- A szerzők egyetemi oktatók és gyakorló jogászok. A tanulmánykötet az „ÁROP 2.2.21 Tudásalapú közszolgálati előmenetel” című kiemelt projekt keretében készült. Arra vállalkozik, hogy bemutassa a kormányzás és közmenedzsment új irányait, a jó közigazgatási eljárás szempontjait, továbbá az Európai Unió tagállamaiban megjelenő megoldási alternatívákat. Az egyes szerzők tanulmányai építkeznek egymásra, ezáltal törekedve a közigazgatás ezen területére jellemző egységes szerkezetnek a bemutatására. A könyvet elsősorban a doktori és mesterképzésben részt vevő hallgatók forgathatják haszonnal, tekintettel arra, hogy már meglévő ismeretekre alapozva célozza meg problémák felvetését, eltérő megközelítéssel bíró fogalmak bemutatását. (K. K. E.) 
- Magyarország és a védelmi igazgatás rendszere Kiss Zoltán (szerk.)

(Sorozat: Védelmi igazgatás, hagyomány és megújulás; ISSN 2064-3306)

Harmadik, változatlan utánnyomás. Zrínyi, Budapest, 2014

Szakkönyv. Terjedelem: 177. Bibliográfia a lábjegyzetekben.

ISBN 9789633275405

- A könyv változatlan utánnyomás, a 2012-es kiadást a Pro Futuro 2015/2. számában annotáltuk. (B. A.)

- Közszolgálat és fenntarthatóság

Knoll Imre-Lakatos Péter (szerk.)

Nemzeti Közszolgálati Egyetem, Budapest, 2014

Tanulmánykötet. Terjedelem: 161. Bibliográfia: 159-161. és a fejezetek végén. ISBN 9786155491641

- A szerzők egyetemi oktatók és gyakorlati szakemberek. A könyv középpontjában a fenntarthatóság áll, amit a készítők több aspektusból közelítenek meg. Ehhez szorosan igazodik a tanulmánykötet szerkezeti felépítése, így nyolc terület fenntarthatósági jellemzőit ismerheti meg az olvasó. Első lépésben alapfogalmak kerülnek meghatározásra, mint a fenntarthatóság mérése, értékelése. Ezt követően a fenntarthatóság szakigazgatási területeken (nemzetgazdasági szektor, közigazgatás, katonai művelet, rendőrség, katasztrófavédelem) betöltött szerepét fogalmazzák meg a szerzők. A könyv rávilágít a hosszú távú fejlődés lehetőségére, aminek az eléréséhez a fentebb felsorolt területek egymás iránti tisztelete nélkülözhetetlen. (K. K. E.)

- A közigazgatás-tudományi nézetek fejlödése - Külföldi hatások a magyar közigazgatási jog és közigazgatástan művelésében a kameralisztika időszakától a Magyary-iskola koráig

Kol Gyula

Nemzeti Közszolgálati és Tankönyv Kiadó, Budapest, 2014

Monográfia. Terjedelem: 487. Bibliográfia: 355-412. ISBN 9786155344640

- A szerző egyetemi oktató és kutató. A 2014-ben - a győri jogi karon - megvédett doktori értekezésen alapuló könyv célja a hazai közigazgatás-tudományi nézetek bemutatása tudománytörténeti szempontból, különös tekintettel a széles értelemben vett külföldi hatásokra. A magyar „iskolák” (művelőinek fogalomhasználata, jogfilozófiai háttere, iskolázottsága stb.) mellett vizsgálja a rendszeralkotó közigazgatás-tudományi ágakat külföldön, különös tekintettel a francia, a német és az angolszász struktúrákra. A széles körü kitekintés érdekében a szerző nagyszámú külföldi szakirodalmi forrásra támaszkodott. (K. B.)

- Médiajogi kommentárok

Koltay András-Lapsánszky András (szerk.)

Wolters Kluwer, Budapest, 2014

Kommentár. Terjedelem: 641. Bibliográfia: 607-612. ISBN 9789632953984 
- A szerzők egyetemi oktatók és gyakorló jogászok. A kiadvány a sajtószabadságról és a médiatartalmak alapvető szabályairól szóló 2010. évi CIV. törvény és a médiaszolgáltatásokról és a tömegkommunikációról szóló 2010. évi CLXXXV. törvény 2014. január 1-jén hatályos szakaszainak magyarázatát tartalmazza. A kommentár a továbbiakban áttekinti a médiaszolgáltatásokra és sajtótermékekre vonatkozó általános szabályokat, a közszolgálati médiaszolgáltatást, valamint foglalkozik a médiaszolgáltatásokra és sajtótermékek felügyeletére vonatkozó szabályokkal is. A belső joganyag értelmezése mellett a szerzők figyelmet fordítottak az európai uniós jognak való megfelelés vizsgálatára is. (K. B.)

- Magyarország védelmi igazgatása a közigazgatás új környezetében Szentes László (szerk.)

(Sorozat: Védelmi igazgatás, hagyomány és megújulás; ISSN 2064-3306)

Zrínyi, Budapest, 2014

Szakkönyv. Terjedelem: 382. Bibliográfia a lábjegyzetekben.

ISBN 9789633276174

- A kiadvány szerzői a területen komoly jártassággal rendelkező szakemberek. A védelmi igazgatás komplex rendszer, amelynek sikeres müködéséhez számos szereplö hatékony munkájára van szükség. A kötetböl részletesen megismerhetjük a honi védelmi adminisztráció történetét, valamint intézmény- és tervrendszerét. Ezenfelül a szakkönyv részletesen taglalja az intézményrendszer mögötti infokommunikációs hálózatot, és pontos képet ad a riasztás-értesítés feladatairól. A szakkönyv végén színes ábrák és táblázatok kerültek elhelyezésre. A munkához tartozó DVD-mellékleten további hasznos információk, például oktatófilmek találhatóak. (B. A.)

- A verseny hálójában: aktuális versenyjogi kérdések a hírközlés liberalizációja terén Vallyon Emese-Vittay Melinda (szerk.)

ELTE Bibó István Szakkollégium a Felelős Értelmiségért Alapítvány, Budapest, 2014

Tanulmánykötet. Terjedelem: 124. Bibliográfia: 113-115. és a fejezetek végén. ISBN 9789638870063

- A tanulmánykötet szerzői az ELTE Bibó István Szakkollégiumának tagjai (hallgatók), akiknek az érdeklődési területe elsősorban a versenyjog, nemzetközi magánjog, közbeszerzési jog területére esik. A kötet képet ad a versenyjogi szabályozás aktuális helyzetéről, figyelemmel a technológiai fejlődés következtében jelentkező változásokra. A szakterületen kiemelt jelentőséggel bíró témakörök kerülnek bemutatásra, így a távközlési és postapiaci liberalizáció, a monopóliumszabályozás, a mobilpiacra való állami belépés lehetőségei, az állami támogatások megengedhetősége és a fúziókontroll. A munka célja vállaltan az, hogy felkeltse a figyelmet ezen témák iránt. Egyaránt haszonnal forgathatják egyetemi hallgatók, gyakorló jogászok és laikus érdeklődők. (K. K. E.) 


\section{MUNKAJOG}

- Az Európai Üzemi Tanács

ÁsvánYı Zsófia

Pécsi Tudományegyetem Felnőttképzési és Emberi Erőforrás Fejlesztési Kar, Pécs, 2014

Monográfia. Terjedelem: 232. Bibliográfia: 224-232. és a lábjegyzetekben. ISBN 9789636426279

- A szerző egyetemi oktató. Kollektív munkajogi tárgyú írása a Pécsi Tudományegyetemen 2013-ban megvédett doktori értekezésen alapul, az uniós és a magyar jogban megjelenő munkavállalói participációs jogok bemutatását célozza. A monográfia a részvételi jogok uniós szabályozási szintjének bemutatását követően a participációs jogkatalógus egyes részjogosítványainak elemzésére törekszik, s megismerteti az olvasókkal a munkáltató szerkezetátalakításához, az atipikus jogviszonyokhoz és a munkabiztonsághoz kapcsolódó munkavállalói részvételi jogokat. A monográfia központi részét képezi az Európai Üzemi Tanács elméleti szintü bemutatása mind az uniós, mind pedig a magyar jog szemszögéből. Ennek keretében részletes bemutatásra kerül többek között a különleges tárgyaló testület és a közösségi szintű vállalkozás is. Az elmélet azonban mit sem ér gyakorlati igazolás nélkül: ennek jegyében a szerző hazánk és az Európai Unió gazdag joggyakorlatát elemezve támasztja alá hipotéziseit. (Sz. A.)

- Egységes szerkezetbe foglalt munka törvénykönyve magyarázatokkal a munkaadók számára a 2012. évi l. törvény alapján

BÁLINT Adrienn-LóROdı László

Második, javított, átdolgozott kiadás. MGYOSZ, Budapest, 2014

Kommentár. Terjedelem: 224. Bibliográfia a lábjegyzetekben.

ISBN 9789638916365

- A szerzők gyakorló jogászok és munkajoggal foglalkozó szakemberek. A kötet a Munkaadók és Gyáriparosok Országos Szövetsége kiadásában készült, s célja, hogy a munka törvénykönyve (Mt.) rendelkezéseit az azt alkalmazók számára érthető magyarázatokkal lássa el. A szerzők kimondottan a mindennapi jogalkalmazást segítő, gyakorlatias megközelítéssel kívántak élni a tudományos mélységü értelmezés helyett, így a bírói gyakorlat beépítése mellett táblázatok vannak az olvasó segítségére a jogszabály értelmezése során. A kommentár a korábbi kiadáshoz képest tartalmazza az Mt. 2012 óta bekövetkezett módosításait, a jogszabály 2014. június 1-jei időállapotát tükrözi. (B. K.)

\section{- A munkajogviszony megszünése a magyar munkajogban}

BANKó Zoltán

Utilitates Bt., Pécs, 2014

(Sorozat: Pécsi Munkajogi Közlemények, Monográfiák; ISSN 2416-075X; 3.)

Monográfia. Terjedelem: 206. Bibliográfia: 203-206. és a lábjegyzetekben. ISBN 9786158010511 
- A szerző egyetemi oktató. Monográfiája a munkaviszony megszüntetésének legföbb kérdéseit gyüjti össze, és egyúttal értékeli annak dogmatikai, jogalkotási és jogalkalmazási aspektusait. A mủ a munkajogviszony megszűnésével kapcsolatos szabályozás történeti áttekintését követően a hatályos szabályrendszerre fókuszál, bemutatva az egyes megszünési és megszüntetési módokat, valamint azok jogkövetkezményeit. Külön fejezetben vizsgálja továbbá a megszüntetés alapjogi összefüggéseit, hangsúlyt fektetve a kapcsolódó alkotmánybírósági döntések feldolgozására. Mindezek mellett a szerző a nemzetközi kitekintés révén a magyar szabályanyag európai tendenciákkal történő összehasonlítását is megkísérli, elemezve mind az Európai Unió, mind pedig a fontosabb nemzetközi szervezetek, így az ILO és az Európa Tanács vonatkozó dokumentumait. (Sz. A.)

\section{- A rugalmas foglalkoztatás munkajogi megoldásai}

BANKó Zoltán

Utilitates Bt., Pécs, 2014

(Sorozat: Pécsi Munkajogi Közlemények, Monográfiák; ISSN 2416-075X; 1.)

Monográfia. Terjedelem: 217. Bibliográfia: 187-216. és a lábjegyzetekben.

ISBN 9789630888967

- A szerző a Pécsi Tudományegyetem oktatója. A könyv kiindulási alapja a szerző PhD-értekezése alapján 2010-ben már megjelent „Az atipikus munkajogviszonyok" címet viselö müve (annotáltuk a folyóirat 2012/1. számában). Ennek átdolgozott és kibővített változata a jelen kötet, amely tartalmazza a szerzőnek az azóta bekövetkezett jogalkotási fejleményekkel, így a 2012-es munka törvénykönyve szabályanyagával, valamint az újabb jogalkalmazási eredményekkel kapcsolatos megállapításait. Vizsgálata kiterjed a tipikustól eltérő foglalkoztatási formákra, létrejöttük okaira, valamint a rugalmas foglalkoztatás szociális következményeire is. A kötet átfogó elemzésre törekszik, ezért magában foglalja a rugalmas foglalkoztatás részletes ismeretanyagát. $A$ mű első felében a szerző ismerteti a téma alapvető fogalmait, valamint a releváns foglalkoztatási formákat. A második részben az olvasó képet kap az egyes atipikus munkaviszonyok, így többek között a távmunka, a bedolgozói jogviszony és a munkaerö-kölcsönzés szabályozásáról. (Gy. B.)

- A kollektív szerződés a magyar munkajogban

Berke Gyula

Utilitates Bt., Pécs, 2014

(Sorozat: Pécsi Munkajogi Közlemények, Monográfiák; ISSN 2416-075X; 2.)

Monográfia. Terjedelem: 220. Bibliográfia: 206-220. és a lábjegyzetekben. ISBN 9786158010504

- A szerző egyetemi oktató, múve egy az OTKA által támogatott kutatáson alapul. Célja a kollektív szerződéssel kapcsolatos joganyag áttekintése a hazai jogalkotásban, jogalkalmazásban, valamint a munkajog-tudományban, elsősorban jogtörténeti nézőpontból. Ezért monográfiája a kollektív szerződésre vonatkozó szabályanyagot annak a magyar munkajogban való megjelenésétöl, azaz a 20. század elejétől kezdődően elemzi. A kötet három föbb részből áll: a jogelméleti 
fejezetben a szerző ismerteti a kollektív szerződéssel kapcsolatos elméleteket, majd ezt követi a szocialista munkajog elemzése a kollektív szerződés szempontjából. Az utolsó fejezet a piacgazdaság keretei között vizsgálja a kollektív szerződés intézményét, amelyben az 1992. évi és a 2012. évi munka törvénykönyve szabályainak bemutatására kerül sor. (B. K.)

- Kommentár a munka törvénykönyvéhez: Kommentár a munka törvénykönyvéröl szóló 2012. évi l. törvényhez

Bankó Zoltán-Berke Gyula-KaJTÁR Edit-Kıss György-Kovács Erika

Második, átdolgozott kiadás. Wolters Kluwer, Budapest, 2014

Kommentár. Terjedelem: 828. Bibliográfia nincs. ISBN 9789632954158

- A szerkesztők és a szerzők egyetemi oktatók és gyakorló jogászok. A kötet a 2012-es (első) kiadás 2014. július 1-jével hatályosított változata, amely tartalmazza a munka törvénykönyvének a 2013. évi polgári törvénykönyv hatálybalépése miatt módosított rendelkezéseinek magyarázatát is. Ezen túlmenően a szerzők feldolgozzák az európai munkajog, valamint az Európai Unió Bírósága gyakorlatának az első kiadás óta bekövetkezett változásait, fejleményeit. Az első kiadás annotációját lásd a Pro Futuro 2014/1. számában. (B. K.)

- A közalkalmazottak jogállásáról szóló törvény és magyarázata CsÉFFÁn József Szegedi Rendezvényszervező Kft., Szeged, 2014

Kommentár. Terjedelem: 970 . Bibliográfia a lábjegyzetekben. ISBN 9786155112058

- A szerző a Szegedi Tudományegyetem tiszteletbeli tanára, egyben kollégiumvezető bíró. Könyvének célja, hogy segítséget nyújtson a közalkalmazottak jogállásáról szóló 1992. évi XXXIII. törvény (Kjt.) megértéséhez és alkalmazásához. A kötet a jogszabályokat a 2014. január 2-i időállapot szerint dolgozza fel. A korábbi lezárással, önálló kiadványként megjelent kommentárt a Pro Futuro 2014/1. számában már annotáltuk. Az új verzió az azóta eltelt jogszabályi változások alapján készült. (Gy. B.)

- A munka törvénykönyve és magyarázata

CsÉFFÁn József

Szegedi Rendezvényszervező Kft., Szeged, 2014

Kommentár. Terjedelem: 829. Bibliográfia nincs. ISBN 9786155112072

- A szerző a Szegedi Tudományegyetem tiszteletbeli tanára, egyben kollégiumvezetö bíró. Könyvében a munkajogviszonyra vonatkozó jogszabályok hatályos rendelkezéseihez fúz magyarázatot a már módosított munka törvénykönyve és a polgári törvénykönyvnek a munkaviszonyban alkalmazandó hatályos rendelkezései alapján. A kötet a jogszabályokat a 2014. január 2-i időállapot szerint dolgozza fel. A korábbi lezárással, önálló kiadványként megjelent kommentár a Pro Futuro 2014/1. számában már annotálásra került. Az új verzió az azóta eltelt jogszabályi változások alapján készült. (S. B.) 
- A munka- és pihenőidő szabályai

DudÁs Katalin

CompLex, Budapest, 2014

(Sorozat: Munkajogi Kiskönyvtár; ISSN 2063-6393; 4.)

Szakkönyv. Terjedelem: 238. Bibliográfia a lábjegyzetekben.

ISBN 9789632953779

- A szerző az Eötvös Loránd Tudományegyetem oktatója, egyben gyakorlati szakember. A kiadvány átfogó jelleggel mutatja be a munkaidő és a pihenőidő szabályainak legfontosabb rendelkezéseit. Bár a könyv szerkezete nem követi a munka törvénykönyvének felépítését, a mű mégis logikus, az elvi alapoktól építi fel a tartalmat. A munka törvénykönyvében található szabályokon kívül helyet kapott több, a munka- és pihenőidő vonatkozásában releváns miniszteri rendelet elemzése, valamint ismertetésre kerül az Európai Uniónak a témakörhöz tartozó irányelve is. Ily módon a szerző komplex képet tár az olvasó elé a munka- és pihenőidő szabályairól, amelyek jobb megértését táblázatok is segítik. A kézirat 2014. január 31-ei lezárású, az elemzett szabályanyag ezt az időállapotot tükrözi. (Gy. B.)

- A szürke állomány: Gazdaságilag függő munkavégzés a munkaviszony és az önfoglalkoztatás határán

GYULAVÁRI Tamás

Pázmány Press, Budapest, 2014

(Sorozat: A Pázmány Péter Katolikus Egyetem Jog- és Államtudományi Karának Könyvei, Jogtudományi Monográfiák; ISSN 2061-5191; 6.)

Monográfia. Terjedelem: 332. Bibliográfia: 291-326. és a lábjegyzetekben. ISBN 9789633081914

- A szerző egyetemi oktató. Célja a munkajogviszony és a tiszta önfoglalkoztatás között található, gazdaságilag függő munkavégzést fedő jogviszonyok, vagyis az ún. szürke zóna bemutatása. A kötet elején a szerző tisztázza az alapvető munkajogi fogalmakat, köztük a munkaviszony, a munkavállaló és az önfoglalkoztató definícióját az uniós és a hazai jogban, majd ezt követően elemzi e fogalmak átalakulását az Európai Unióban. Vizsgálata tárgyává teszi a gazdaságilag függő munkavégzés uniós tagállamokban kialakított szabályozási megoldásait is, a szürke zónába tartozó speciális jogviszonyokat, valamint a munkajogból történő menekülés jelenségét. Teszi mindezt széles körü külföldi és hazai szakirodalmi bázisra alapozva, valamint az Európai Unió Bíróságának esetjogát áttekintve. A szerző a kötet végén egy összegző fejezetben gyűjti egybe jelentősebb észrevételeit és konklúzióit. (B. K.)

- Munkajogi feladatok és jogesetek

Gyulavári Tamás-Hős Nikolett-Kártyás Gábor (szerk.)

ELTE Eötvös, Budapest, 2013

(Sorozat: ELTE Jogi Kari Jegyzetek; ISSN 2060-5986; 11.)

Feladatgyűjtemény. Terjedelem: 185. Bibliográfia nincs. ISBN 9789633121740

- A szerzők és szerkesztők egyetemi oktatók, illetve gyakorló jogászok. Könyvük 150 jogeseten és 50 gyakorlati feladaton keresztül igyekszik segíteni a gazdasági 
munkaviszony legfontosabb szabályainak megértését és elsajátítását. A feladatgyüjtemény 12 tematikus fejezete a munkajog alapvető jogintézményeinek megértésére szolgál, mint például a munkaviszony létesítése és megszüntetése, a munka- és pihenőidő, a munkabér, illetve a munkáltatót és munkavállalót terhelő kártérítési felelősség. Az individuális munkajog mellett a kollektív munkajog és az atipikus munkaviszonyok köréböl is tartalmaz feladatokat. A kiadvány végén található a tesztek megoldása az elsajátított ismeretanyag ellenőrzése céljából. A kézirat 2013. június 10-ei lezárású. (Sz. A.)

\section{- Munkajog}

Hajdú József-Kun Attila (szerk.)

Patrocinium, Budapest, 2014

Tankönyv. Terjedelem: 450. Bibliográfia: 443-450. és a lábjegyzetekben. ISBN 9786155337901

- A szerzők egyetemi oktatók és gyakorló jogászok. A kötet részletesen bemutatja a nemzetközi és európai munkajog alapjait, valamint a gazdasági munkaviszonyra vonatkozó hazai szabályokat, a létesítéstől kezdődően egészen a megszűnésig. Tartalmazza továbbá a közszolgálati tisztviselökre és a közalkalmazottakra vonatkozó szabályanyag, valamint a munkavédelem és a munkaügyi ellenörzés rendszerének ismertetését. A szerzők a 2014. november 17-én lezárt müvet kimondottan tankönyvnek szánják, amely segítséget nyújthat a joghallgatók számára a munkajog elsajátításához, amit táblázatok, az életből vett példák, a bírói gyakorlat, valamint a vonatkozó nemzetközi és uniós szabályok ismertetése tesz könnyebbé. A kötet a Nemzeti Kulturális Alap támogatásával jelent meg. (B. K.)

\section{PÉNZÜGYI JOG}

- A közigazgatás gazdaságtana. A gazdasági kormányzás lehetőségei és dilemmái BordÁs Mária Dialóg Campus, Budapest-Pécs, 2014

Monográfia. Terjedelem: 317. Bibliográfia: 305-319. és a lábjegyzetekben. ISBN 9786155376375

- A szerző egyetemi oktató. Arra a kérdésre keresi a választ, hogy a közigazgatás milyen szereppel bír a gazdasági folyamatok alakításában, s előbbi feladatok betöltésére milyen eszközök állnak rendelkezésre. A kiadvány a fogalmi alapozás és a történeti áttekintés után külön fejezetben tárgyalja a gazdaságpolitikát meghatározó tényezőket, illetve a gazdasági közigazgatás szerepét elöbbi szakpolitika alakításában. A szerző később külön egységekben ismerteti azokat a szabályozási területeket - mint a versenyfelügyelet, a közszolgáltatások szabályozása, az állami tulajdon, illetve közpénzek felhasználása -, melyeken keresztül az állam a közigazgatás révén a leghatékonyabban képes alakítani a gazdasági folyamatokat. A szerző ebben a munkájában is a rá jellemző módon épít a jog- és közgazdaság-tudományra, valamint a (köz)menedzsment eredményeire, így a vizsgált témát sajátosan s több aspektusból közelíti meg. (V. J.) 
- Gondolatok és tények a helyi adózás rendszerében: önkormányzatoknak, vállalkozóknak, természetes személyeknek és minden érdeklődőnek

DELI Lajos-Boros Erzsébet-MaKó Cecília

Kompkonzult, Budapest, 2014

Kézikönyv. Terjedelem: 234. Bibliográfia: 233. ISBN 9789639427938

- A szerzők az adóigazgatás terén jártas szakemberek. A kötet a helyi önkormányzatok saját bevételeinek egyik meghatározó elemét, a helyi adókat vizsgálja adóeljárásjogi aspektusból. A gyakorlati aktualitások tárgyalását követően két nagy fejezetre tagolódik. Az egyik a helyi adókról szóló és az adózás rendjéről szóló törvény adóigazgatási eljárásban alkalmazandó legfontosabb szabályait mutatja be. Kitér az adóhatósági intézkedésekre, a végrehajtási eljárás egyes jogintézményeire és a döntéshozatal gyakorlati tapasztalataira. A másik fejezetében a helyi adók ellenőrzése kerül bemutatásra. A szerzők elemzik az adóellenőrzés formáit, az ellenőrzésre történő kiválasztás szempontjait, az ellenőrzés menetét befolyásoló tényezőket, valamint ezek gyakorlati tapasztalatait. Utóbbi cél elérése érdekében számtalan gyakorlati példa, esettanulmány, jogértelmezési kérdés, állásfoglalás kerül feldolgozásra, bemutatásra. (B. P.)

\section{- Az önkormányzatok sportfinanszírozása Magyarországon}

GYömÖREI Tamás

(Sorozat: Regionális és Gazdaságtudományi Kismonográfiák; ISSN 2064-4698)

Publicon, Pécs-Győr, 2014

Kismonográfia. Terjedelem: 166. Bibliográfia: 135-145. ISBN 9786155376344

- A szerző egyetemi oktató, a könyv a 2012-ben megvédett doktori disszertációjának továbbfejlesztett változata. A mű a hazai szakirodalomban elsőként vállalkozik a helyi önkormányzatok sportfinanszírozásban vállalt szerepének bemutatására. A modern sport fogalmi meghatározása mellett a szerző megvizsgálja az európai sportpolitikákat és sportszabályozásokat, az állam szerepét a modern magyar sportban, az önkormányzati támogatások előnyeit. A kötet valódi nóvumát a sportban sikeres városok sportrendszereinek, valamint sportgazdálkodásának összehasonlító, empirikus elemzése adja. Számos ábra, táblázat segíti az eredmények bemutatását, értelmezését. A könyv rendhagyó a tekintetben is, hogy a zárógondolatokat egy angol nyelvü fejezet követi, amely a legfontosabb hipotézisek és eredmények idegen nyelvü összefoglalását tartalmazza. (B. P.)

- Pénzügyi jog III.

Halustyik Anna (szerk.)

(Sorozat: PPKE JÁK Tankönyvei; ISSN 2062-0837)

Pázmány Press, Budapest, 2014

Tankönyv. Terjedelem: 397. Bibliográfia a lábjegyzetekben.

ISBN 9789633080962

- A szerkesztő és a szerzők egyetemi oktatók. A kiadvány egy háromrészes pénzügyi jogi tankönyvsorozat - tematikusan - harmadik, ám időben elsőként megjelent darabja. A kötet hat nagy témakör: a számviteli jog, a hazai és uniós társasági jogi szabályozás, a hazai személyi jövedelem, valamint a kis- és középvállalko- 
zások adózása, a pénz- és tőkepiaci szabályozás, továbbá az európai adójogi rendelkezések bemutatására vállalkozik. A mű a kiválasztott témaköröket logikus, követhető és áttekinthető módon tárja az olvasó elé, elsősorban a megjelenéskor hatályos jogszabályi előírásokból kiindulva. Ez utóbbi körülményből - jelesül az adójogi elóírások dinamikus változásából - fakad a kiadvány egyik gyenge pontja, hisz kérdés, hogy a 2014-ben alkalmazandó szabályok meddig maradnak hatályban. (V. J.)

- A helyi adók és a gépjármüadó jogmagyarázata

HeIZER-KIss Zsófia-KanYó Lóránd

(Sorozat: Adózási Kézikönyvek; ISSN 1788-0165)

Saldo, Budapest, 2014

Kézikönyv. Terjedelem: 178. Bibliográfia nincs. ISBN 9789636384593

- A szerzők a helyi adózásban jártas szakemberek, a Nemzetgazdasági Minisztérium munkatársai. A könyv a helyi adókról szóló 1990. évi C. törvény 2014-ben hatályos szövegváltozatának feldolgozását, magyarázatát tartalmazza. Áttekintésre kerülnek a helyi adóztatás általános kérdései, szabályai, az önkormányzatok adómegállapítási jogköre, majd a helyi adók rendszere. Ezt követően az egyes helyiadó-típusok adótényállási elemenkénti, részletes kifejtésére kerül sor, azaz az építményadó, a telekadó, a magánszemélyek kommunális adója, az idegenforgalmi adó és végezetül az iparüzési adó. A helyi adók mellett elemzés tárgyát képezi a gépjármủadó is mint átengedett központi adó. A részletszabályok bemutatása mellett a szerzők gondot fordítottak arra is, hogy példákon végigvezetve könnyítsék meg az adózási folyamatok megértését. Nagy segítséget jelenthet a könyv mind az adózóknak, mind pedig a helyi adórendeleteket megalkotó képviselö-testület, szakapparátus számára. (B. P.)

- Adó Magyarázatok 2014

Herich György (szerk.)

(Sorozat: Adó abc; ISSN 1426-8111)

Penta Unió, Pécs, 2014

Kézikönyv. Terjedelem: 476. Bibliográfia nincs. ISBN 9786155249129

- A könyv az Adótan kötetének huszonötödik, átdolgozott kiadásával képez szerves egységet. A korábbi kiadás annotációját lásd a Pro Futuro 2015/1. számában. (B. P.)

- Adótan

HeRICH György

(Sorozat: Adó abc; ISSN 1426-8111)

Penta Unió, Pécs, 2014

Kézikönyv. Terjedelem: 435. Bibliográfia a lábjegyzetekben.

ISBN 9786155249136

- A könyv az Adó abc Adótan kötetének huszonötödik, átdolgozott kiadása. A huszonnegyedik kiadás annotációját lásd a Pro Futuro 2015/1. számában. (B. P.) 
- Gyürük és sugarak. Mit nyújt egy magyar város?

Horváth M. Tamás-Bartha Ildikó (szerk.)

(Sorozat: Közszektor-olvasmányok; ISSN 1417-7986)

Dialóg Campus, Budapest-Pécs, 2014

Tanulmánykötet. Terjedelem: 344. Bibliográfia a fejezetek végén.

ISBN 9786155376351

- A szerzők gyakorlati szakemberek, egyetemi oktatók. A kötet Hajdúböszörmény példáján keresztül mutatja be a helyi közszolgáltatások nyújtásának és szervezésének gyakorlatát. Tizenhat tanulmánya három téma köré összpontosul, melyek a vállalati körök, kifordulók, nyalábok és zugok figyelemfelkeltő címeket viselik. Elemzés tárgyát képezik többek között a helyi költségvetés, a képviselö-testület müködése, a helyi közvállalatok, a kulturális feladatok, az egészségügyi ellátás, a szociális szolgáltatások, hatósági szolgáltatások, az egyházak közszolgáltatásban betöltött szerepe, a köztemető üzemeltetése, a rendészeti közszolgáltatások, a civilszervezetek szerepköre, a gyermekvédelem lokális rendszere vagy épp az önkormányzati tulajdonú gazdasági társaságok térnyerése a közszolgáltatások biztosításában. Egyedülálló, empirikus kutatatás eredményét vehetjük kézbe, amely nemcsak a gyakorlati szakemberek számára nyújthat új információkat, hanem hasznosítható az egyetemi oktatásban is, és a hétköznapi olvasó számára is érdekes. (B. P.)

- Külön utak. Közfeladatok megoldásai

Horváth M. Tamás (szerk.)

(Sorozat: Közszektor-olvasmányok; ISSN 1417-7986)

Dialóg Campus, Budapest-Pécs, 2014

Tanulmánykötet. Terjedelem: 375. Bibliográfia a fejezetek végén. ISBN 9786155376344

- A szerzők gyakorlati szakemberek, egyetemi oktatók. A közszolgáltatások megszervezése eltérő módon zajlik mind ágazatonként, mind pedig államonként, de mégis vannak jellemző modellek, melyek ismerete kulcsfontosságú. A kötet e célra vállalkozik a hálózatos szolgáltatások, úgymint a víz-, energiaellátás és a nagy humán szolgáltatások, különösen a szociális, köz- és felsőoktatás területén. Tizennégy tanulmány ad betekintést az egyes ágazati modellek, uniós politikák és empirikus modellek adta keretek közé. Nemcsak a közszolgáltatás-szervezés elméleti kérdéseit boncolgatják, hanem több esetben reagálnak a 2010-es évek magyarországi változási folyamataira. Különös hangsúlyt kap a pénzügyi decentralizáció, az egyház-finanszírozás, az állami szerepvállalás kérdésköre. A könnyebb megértést számtalan táblázat, adattábla, grafikon és függelék segíti. (B. P.)

- A közbeszerzésröl másképpen - köz- és magánjog határán

JuHÁsz Ágnes

Lectum, Szeged, 2014

Monográfia. Terjedelem: 368. Bibliográfia: 333-351. ISBN 9789639640504

- A szerző egyetemi oktató. Jelen kötete a közbeszerzés összetett területén tapasztalható - elméleti és gyakorlati - hiányosságokra tekintettel kíván átfogó ismeretet 
nyújtani, 2011-ben megvédett doktori értekezése alapjain. Elméleti szinten, közés magánjogi aspektusból is vizsgálja a területet; majd a hatályos magyar szabályozásban segíti az eligazodást, így a közbeszerzési törvény, valamint a Ptk. vonatkozó részének alkalmazását. Növeli a mű értékét, hogy a magyar szabályozás mellett számos EU-tagállam (például Németország, Románia) szabályozási koncepciója is bemutatásra kerül. A szerző hangsúlyt fektet a marginális, de mégis problémás kérdésekre, mint például a „házon belüli beszerzések”. Interdiszciplináris szemléletmódjának köszönhetően a kapcsolódó versenyjogi és büntetőjogi vonulatok is az elemzés tárgyát képezik. A könyv - a kitűzött céljának megfelelöen - a feldolgozásra kerülö gazdag esetjognak köszönhetően a kutatók mellett a gyakorlati szakemberek számára is segítségül szolgálhat. (H. K.)

- A jegybanki függetlenség fejlődéstörténetének vizsgálata a XVIII. századtól napjainkig

KOVÁCSNÉ Sipos Ágnes

Budapesti Gazdasági Főiskola, Budapest, 2014

Monográfia. Terjedelem: 297. Bibliográfia: 281-297. ISBN 9789637159657

- A szerző a Budapesti Gazdasági Főiskola oktatója, jelen munkája a 2007-ben megvédett doktori értekezésének könyvváltozata. A kutatás időben és térben is jelentős kiterjedésű, hiszen az elemzést a 18. századtól vezeti végig, s a vizsgálódás az Európai Unió számos tagállamának (osztrák, német, brit, francia stb.) rendszerét veszi górcső alá, sőt az amerikai kontinensre is kitekint. A mű meghatározó részében történeti forrásfeldolgozó munka, ily módon bemutatva egyfelöl a vizsgált országok különféle szabályozási struktúráját, másfelöl pedig az eltérő utakon elért egységet, vagyis a Központi Bankok Európai Rendszerének való megfelelést. Bár a dolgozat megírása óta a gazdasági válság a jegybanki függetlenséget is több vonatkozásban kihívások és változások elé állította, mivel a teoretikai alapok konstansnak mondhatók, így az a továbbiakban is alapul szolgálhat a téma kutatóinak. (H. K.)

\section{- Az államadósság-válság kezelése az EU-ban}

Losoncz Miklós

Tri-Mester, Tatabánya, 2014

Monográfia. Terjedelem: 414. Bibliográfia: 390-411. és a lábjegyzetekben. ISBN 9789639561274

- A szerző közgazdász, egyetemi tanár. Kötete a 2008-as pénzügyi válság hatására a Gazdasági és Monetáris Uniót (GMU) ért adósságválság fejleményeit, tapasztalatait és dilemmáit vizsgálja. A munka központjában a GMU-intézményrendszer, annak müködése és az áll, hogy az egyes államok adósságválsága hogyan hatott a GMU müködésére, valamint, hogy a tagállamok, illetve az uniós intézmények milyen változásokat hajtottak végre a válságkezelés jegyében 2009 novemberét követöen 2014-ig. A fentiekkel összefüggésben olyan érdekes kérdések merülnek fel a kötetben, mint hogy fenntartható-e a közös monetáris politika, vagy hogy lehet-e a közös felelősség- és tehervállaláson alapuló fiskális uniót helyettesíteni. A kiadvány érdekes és elgondolkodtató olvasmány valamennyi, a téma iránt érdeklődő elméleti és gyakorlati szakember számára. (V. J.) 
- A számvitel és az adózás időszerü kérdései 2014

MADARASINÉ DR. SzIRMAI Andrea-SIKLÓsı Ágnes-SzTANó Imre-SzTANó Imréné-Veress Attila

Perfekt, Budapest, 2014

Kézikönyv. Terjedelem: 264. Bibliográfia a fejezetek végén.

ISBN 9789633948293

- A szerzők tudományos kutatók és gyakorlati szakemberek. A 2013-ban azonos címen megjelent kiadványtól a 2014-ben kiadott munka mind tartalmában, mind tematikájában eltér, ám a szerzők által kitűzött célok változatlanok. A 2014-es kötet is a korábbi időszakhoz képest kívánja bemutatni a számviteli jogban, illetve a legjelentősebb adókra - szja, tao, áfa, kiva, eva, kata, ekho, helyi adók és a gépjármủadó - vonatkozó előírásokban - 2013 óta - bekövetkezett változásokat. A kötet egyaránt ajánlható pénzügyi jogi, számviteli stúdiumok hallgatói és gyakorlati szakemberek figyelmébe, kiegészítve az adójogban azóta bekövetkezett változásokkal. (V. J.)

\section{- A társadalombiztosítás pénzügyei}

Novoszáth Péter

Nemzeti Közszolgálati és Tankönyv Kiadó, Budapest, 2014

Kézikönyv. Terjedelem: 244. Bibliográfia: 232-244. ISBN 9786155344619

- A szerző a Nemzeti Közszolgálati Egyetem oktatója. A könyv a témában a „tudományos ür" betöltésének igényével született meg, hogy az elvi alapok mellett átfogóan tárja fel a különböző, eddig kialakult nemzetközi modelleket, rendszereket, a szociális ellátások fejlődéstörténetét. A társadalombiztosítási alrendszerek hazai financiális kérdései alrendszerekre elkülönítve is tárgyalásra kerülnek; közérthető elemzést nyújtva a 2010 óta bekövetkezett változások hátteréről, indokairól. A könyv, bár egy oktatási célra szánt egyetemi tankönyvcsalád része, a feldolgozásra kerülő gazdag tényadatok okán, kutatók és gyakorlati szakemberek eszközéül is szolgálhat. (H. K.)

- A mérhetetlen önkormányzati vagyon

SzABó István

(Sorozat: Regionális és Gazdaságtudományi Kismonográfiák; ISSN 2064-4698)

Publicon, Pécs-Győr, 2014

Kismonográfia. Terjedelem: 158. Bibliográfia: 145-156. és a lábjegyzetekben. ISBN 9786155457043

- A szerző könyvvizsgáló. A kötet célja, hogy felhívja a figyelmet a helyi önkormányzati gazdálkodás költségvetésen kívüli komponensei közül az önkormányzati tulajdonban álló gazdasági társaságok müködésére, a hazai megyei jogú városok példáján keresztül. A mű továbbá rávilágít az aktuálisan működő államháztartási információs rendszer diszfunkcióira is. A kötet három fejezetre tagolt, melyek közül az első a téma elméleti megalapozását adja, a második az önkormányzati tulajdonú gazdasági társaságok irányítási modelljeit veszi sorra, míg a zárófejezet az önkormányzati tulajdoni befolyás alatt álló gazdasági társaságok önkormányzati feladatellátásban való részvételét mutatja be. (V. J.) 
- Pénzügy(rendszer)tan

VIgVÁRI András

Akadémiai Kiadó, Budapest, 2014

Tankönyv. Terjedelem: 469. Bibliográfia a fejezetek végén. ISBN 9789630585958

- A szerző közgazdász, egyetemi tanár. A kötet az író 2008-ban azonos címen napvilágot látott munkájának utánnyomása. Bár a kiadvány tartalma 2008-hoz képest nem változott, azonban ma is aktuális. A kiadvány értékét adja, hogy a háromszintü felsőoktatási rendszer számára készült, így az alap-, mester- és doktori képzésben részt vevő, mind a gazdasági, mind a jogi stúdiumok hallgatói számára ad biztos és értékálló tudásbázist a pénzügyi rendszer struktúrájáról, müködéséről s a rendszeren belül és kívül jelentkező kölcsönhatásokról. A mü összesen tíz fejezetből áll, melyek közül az első kettő a fogalmi alapozásról gondoskodik, s a továbbiak a monetáris, fiskális rendszer s a (nemzetközi) pénzügyi piacok müködésébe engednek betekintést, a szerzőtöl megszokott logikus és konzisztens szerkezetben, letisztult stílusban. Az ismeretek könnyebb elsajátítását ábrák, táblázatok, önellenőrző kérdések és a kiadvány végén helyet kapott glosszárium segítik. (V. J.)

\section{POLGÁRI ELJÁRÁSJOG}

- Öröklési Jog - Hagyatéki eljárás

ANKA Tibor

(Sorozat: Új Magánjog; ISSN 2064-7514; 5.)

HVG-ORAC, Budapest, 2014

Kézikönyv. Terjedelem: 387. Bibliográfia nincs. ISBN 9789632582368

- A szerző közjegyző, a Magyar Országos Közjegyzői Kamara elnökhelyettese. A kötet a szerző 2011-ben megjelent (a Pro Futuro 2013/1. számában ismertetett) munkájának jelentősen kibővített változata; a szerző az új Polgári törvénykönyv szabályanyagának, illetve a mező- és erdőgazdasági földek forgalmáról szóló törvény szabályainak elemzésével őrizte meg annak aktualitását. A mü a teljesség igényével - a gyakorlat nézőpontjából - vizsgálja a hagyatéki eljárás és az öröklési jog szabályait, jelentősen segítve a hagyatéki eljárást lefolytató közjegyzőkön túl a bírák, a hagyatéki eljárással kapcsolatba kerülő jogi képviselők és egyéb érintett hatóságok (jegyző, gyámhivatal) munkáját. (S. I.)

- Jogutódlás a polgári perben (Összehasonlító perjogi elemzés)

GYEKICZKY Tamás

Publikon, Pécs, 2014

Monográfia. Terjedelem: 145. Bibliográfia a lábjegyzetekben. ISBN 9786155457371

- A szerző bíró, főiskolai tanár. A kötet hiánypótló, a hazai jogirodalomban először foglalkozik átfogóan a jogalkalmazás egyik kritikus problémájával, a peres felek személyében bekövetkezett jogutódlás perjogi jogkövetkezményeivel. A könyvet 
jellemzi a komplex feldolgozás igénye. Lényeges kiindulópontja, hogy az anyagi jogi jogutódlás és a perbeli jogutódlás nem azonos intézmények, a bírói gyakorlatban mintaként alkalmazott magánjogi modell nem tartható fenn. Részletes történeti és elméleti kitekintést követően számba veszi azokat az értelmezési nehézségeket, amelyek a perjogi jogutódlás szabályozási hiányosságaiból erednek. A kutatás téziseit a speciális jogviták, a közigazgatási perek kapcsolódó gyakorlatával támasztja alá. Elsődlegesen a németországi jogalkotás tapasztalatait értékelve elöremutató, konkrét szabályozási javaslatot ad. (P. L.)

- Közép-európai polgári perjogi reformok és kodifikációk az elmúlt negyedszázadban - Tradíció és megújulás

Harsági Viktória (szerk.)

HVG-ORAC, Budapest, 2014

Tanulmánykötet. Terjedelem: 261. Bibliográfia a lábjegyzetekben. ISBN 9789632582207

- A kötet az 1911. évi Polgári perrendtartás centenáriuma alkalmából, 2011. október 14-15-én megrendezett német nyelvű konferencián elhangzott előadások átdolgozott anyagát tartalmazza. A szerzők az osztrák, német, olasz, cseh, lengyel, horvát, szlovén, litván, ukrán, bolgár, svájci és román polgári eljárásjog történetét mutatják be, bő két évtized változásaira, fejlődési tendenciáira összpontosítva. A tanulmányok jogtörténeti jellegủek, de a mai perjogi szabályok bemutatására is törekednek. A tanulmánykötetböl egységes képet kaphatunk a környező államok perjogi szabályairól, a különböző jogrendszerek eltéréséröl, hasonlóságukról és egymásra hatásukról. A szerzők az adott ország polgári eljárásjogának részletes bemutatására törekednek, külön kitérnek a polgári eljárásjogban érvényesülő egyes alapelvekre, a magyar jogrendszerben nem ismert jogintézmények bemutatására. (M. T.)

- Új jogalkotási perspektívák és tendenciák Magyarországon és az Európai Unióban Harsági Viktória-Raffai Katalin-Suri Noémi (szerk.)

(Sorozat: A Pázmány Péter Katolikus Egyetem Jog- és Államtudományi Karának Könyvei. Doktorandusz Tanulmányok; ISSN 2064-4078; 2.)

Pázmány Press, Budapest, 2014

Tanulmánykötet. Terjedelem: 319. Bibliográfia a lábjegyzetekben.

ISBN 9789633081716

- A szerzők doktoranduszhallgatók, illetve egyetemi tanársegédek, akik betekintést adnak kutatási tevékenységük egy szeletébe. A tanulmánykötet az azonos címmel, a Pázmány Péter Katolikus Egyetem Jog- és Államtudományi Kar szervezésében, 2013. február 15-ei konferencián elhangzott előadásokat tartalmazza. Egyrészt a polgári perjogi kodifikáció szempontjából hangsúlyos témákat dolgoznak fel, mint a perek időszerüsége, a bírói aktivitás, a csoportos perlés és a bizonyítás egyes kérdései, másrészt összefoglalják a polgári eljárásjogi és nemzetközi magánjogi jogalkotás legújabb eredményeit, többek között az ideiglenes számlazárolás, az európai öröklési bizonyítvány, az elektronikus okiratok felhasználhatósága körében. Az olvasó részletes képet kaphat a magánjog fejlődési irányairól, ezért 
ajánlható a jogterületen dolgozó szakembereknek, az érdeklődő hallgatóknak és kutatóknak egyaránt. (Ny. A.)

\section{- Magyar polgári eljárásjog}

Kengyel Miklós

(Sorozat: Osiris Tankönyvek; ISSN 1218-9855)

Tizenkettedik, átdolgozott kiadás. Osiris, Budapest, 2014

Tankönyv. Terjedelem: 652. Bibliográfia a fejezetek végén. ISBN 9789632762500

- A szerző egyetemi tanár, könyvének első kiadása 1997-ben jelent meg. A polgári eljárásjoggal kapcsolatos joganyag időközben számottevően megváltozott. Az új Polgári Törvénykönyv hatálybalépése indokolta az újabb kiadás megjelentetését, a tankönyv 2012. februári, tizenegyedik kiadásának lezárása után. Egy kötetben foglalja össze mindazokat az ismereteket, amelyeket egy joghallgatónak a polgári perröl tudnia kell. A tankönyv (tizedik kiadásától kezdve) a nemperes eljárásokkal általában, valamint a fizetési meghagyásos eljárással és a bírósági végrehajtással is foglalkozik, mellőzi ugyanakkor a közjegyzői, a cég- és a fizetésképtelenségi nemperes eljárásokat, csökkentve ezzel a tankönyv terjedelmét. A tizenkettedik kiadás újdonsága, hogy megjeleníti a polgári perrendtartás szabályanyagának az új polgári törvénykönyv miatt bekövetkezett változásait. Két korábbi kiadás annotációja a 2012/2. és a 2014/1. számunkban jelent meg. (K. Ba.)

- A polgári per titkai - Kérdések és válaszok a polgári perrendtartás általános részéböl

Kiss Daisy-Sántha Ágnes-Szabó Péter (szerk.)

Harmadik, átdolgozott kiadás. HVG-ORAC, Budapest, 2014

Tankönyv. Terjedelem: 952. Bibliográfia nincs. ISBN 9789632582344

- A könyv kifejezett szándéka segítséget nyújtani a polgári perjogból kollokviumra, szigorlatra, szakvizsgára készülőknek, de a mindennapi jogi munkához is hasznos segítség lehet. A mű a perjogi szabályok elsajátítását a minden fejezethez külön rendelt vázlatokkal, táblázatokkal kívánja segíteni. A kötet első kiadása 2006ban, a második pedig 2009-ben jelent meg. A harmadik, átdolgozott kiadás elkészítésével a 2012-ben elhunyt Kiss Daisy emlékének adóznak egykori kollégái, tanítványai, valamint az ELTE Bibó István Szakkollégium hallgatói, nevelőtanárai. A kötet feldolgozza a korábbi kiadások után bekövetkezett jogszabályváltozásokat, a Polgári perrendtartásról szóló 1952. évi III. törvény 2014. március 15-től hatályos rendelkezéseit tartalmazza. ( $K$. Ba.)

- Bizonyítás a polgári perben

Metzinger Péter

(Sorozat: Bírói Gyakorlat Füzetek; ISSN 2063-725X; 10.)

Opten, Budapest, 2014

Kézikönyv. Terjedelem: 160. Bibliográfia a lábjegyzetekben. ISBN nincs.

- A szerző a Budapesti Corvinus Egyetem Gazdálkodástudományi Karának adjunktusa, ügyvéd, aki a polgári peres bizonyítás témakörét problémaorientált megközelítéssel dolgozza fel. A kézikönyv öt nagyobb fejezetben olyan kérdéseket 
fogalmaz meg, melyekre elöbb az ügy tényállása és a bíróság döntése, majd a döntés értékelése körében ad válaszokat. A bizonyítási kötelezettség témájában hét, a bizonyítás szükségtelensége témájában hét, a szakértői bizonyításról tizenkilenc, az okirati bizonyításról tíz, végül a tanúbizonyításról hat kérdésen keresztül kapunk információkat. Mind a témával foglalkozó kutatók, egyetemi hallgatók, mind a gyakorló jogászok számára nélkülözhetetlen olvasmány. (M. J.)

\section{- A magyar fizetési meghagyásos eljárás az európai megoldások tükrében} Molnár Judit (Sorozat: Studia Notarialia Hungarica; ISSN 1586-8265; 13.) Közjegyzői Akadémia, Budapest, 2014 Monográfia. Terjedelem: 248. Bibliográfia: 233-246. és a lábjegyzetekben. ISBN 9789631202199

- A szerző a Debreceni Egyetem Állam- és Jogtudományi Karának adjunktusa, szakterülete a fizetési meghagyásos eljárás. A szerző 2012-ben megvédett doktori értekezésén alapuló kötet a fizetési meghagyásos eljárás magyar megvalósításának európai gyökereit keresi, felhíva a figyelmet a többi európai megoldáshoz képesti eltérésekre. Részletesen elemzi a fizetési meghagyásos eljárás német és osztrák modelljét, valamint kitér az eljárás közjegyzői nemperes eljárásból fakadó jellegzetességeire és az eljárás elektronikussá tételének szükségességére, annak következményeire. A fizetési meghagyásos eljárások igénybevételének nagy száma a gyakorlati útmutatók megszületésén túl az ilyen tudományos elemzést is szükségessé és hasznossá teszi, mind a tudományos közösség, mind a fizetési meghagyásos eljárással a gyakorlatban találkozók számára. (S. I.)

\section{- Egy új polgári perrendtartás alapjai}

Németh János-Varga István (szerk.)

HVG-ORAC, Budapest, 2014

Tanulmánykötet. Terjedelem: 761. Bibliográfia a lábjegyzetekben. ISBN 9789632582610

- A szerzők a polgári eljárásjog elméleti és gyakorlati jogászai, egyetemi tanárok, bírák, közjegyzők és ügyvédek. A kötet tanulmányai a megszületőben lévő új polgári perrendtartási törvény egyes részterületeit elemzik; többek között az alapelvek, perköltség, bizonyítási eljárás, valamint a nemperes eljárások szabályrendszerét. Részletesen taglalják az adott szakterületek föbb kérdéseit, új megoldásokat vázolnak fel a különbözö jogintézményekkel kapcsolatban. A kötet mellékleteket tartalmaz a polgári perjogi kodifikáció során megszületett kormányhatározatról, valamint statisztikai adatokról. A tanulmányok iránymutatást adhatnak, és közös gondolkodásra sarkallhatják a polgári eljárásjog iránt érdeklődőket. (M. T.)

\section{- Felülvizsgálat polgári perekben}

OszTovits András-VILLÁm Krisztián

(Sorozat: Bírói Gyakorlat Füzetek; ISSN 2063-725X; 12.)

Opten, Budapest, 2014

Kézikönyv. Terjedelem: 279. Bibliográfia nincs. ISBN 9786155122026 
- A szerzők kúriai bírák, elismert tudományos munkássággal. A kötet teljes körüen bemutatja a polgári perekben érvényesülő egyik rendkívüli perorvoslat, a felülvizsgálat kúriai joggyakorlatát. A felülvizsgálat szabályait 1992-ben történt bevezetése óta számos alkalommal jelentősen módosították. A szerzők a kézirat lezárásakor hatályos esetjogot és jogértelmezést, illetve az azt megelőző években született, de ma is irányadó eseti döntéseket veszik alapul. A kötet tíz tematikus fejezetbe rendezi a bírói döntések által megválaszolt kérdéseket, a felülvizsgálat jellege, a felülvizsgálattal megtámadható határozatok és a jogosultak köre, a felülvizsgálat kizártsága, a benyújtás határideje, a mulasztás, a kérelem tartalma és annak elbírálása kapcsán. A fejezeteket a jogi szabályozás és gyakorlat összefoglalása nyitja, ezután a vizsgált döntés által felvetett kérdés következik, majd rövid tényállás-ismertetés, a bíróság konkrét döntése, végül a döntés értékelése. (Ny. A.)

\section{- Az ügyvédi felelösség és biztositása}

SÁNDOR István-Szücs Brigitta

Második, átdolgozott és aktualizált kiadás. HVG-ORAC, Budapest, 2014

Szakkönyv. Terjedelem: 320. Bibliográfia: 280-282. ISBN 9789632582573

- Sándor István habilitált egyetemi docens, Szűcs Brigitta ügyvéd, biztosítási szakjogász. A mű első kiadása 2001-ben jelent meg, az azóta eltelt tizenhárom év alatt Magyarországon a rendszerváltozást követően kialakult gazdasági és társadalmi rend megszilárdult. A megváltozott társadalmi és jogi környezet okán az ügyvédi munka komplexitásának erösödésével megnövekedett az ügyvédek hibázási lehetősége, ami újfajta mühibák megjelenésével járt. Az első kiadás megjelenése óta a jogi környezetben bekövetkezett változások tették továbbá indokolttá a mü aktualizálását. A mủ a 2014 második felében fennálló jogi szabályozást és a bírósági gyakorlatot, ennek megfelelően az ügyvédi felelősségi rendszert, valamint a tipikus ügyvédi mühibáknak tekinthető magatartásokat ismerteti, kitekintve a Magyar Ügyvédek Kölcsönös Biztosító Egyesületének (MÜBSE) gyakorlatára és az ügyvédi felelösségbiztosítás tárgykörére. (K. Ba.)

\section{POLGÁRI JOG}

- Kiskönyv az új Polgári törvénykönyvröl gazdasági szakembereknek Andor Ágnes-LaKatos László Péter Wolters Kluwer, Budapest, 2014 Kézikönyv. Terjedelem: 219. Bibliográfia: 218. és a lábjegyzetekben. ISBN 9789632954103

- A jogász-közgazdász végzettségü szerzők a Budapesti Corvinus Egyetem oktatói, kiadványukat kifejezetten könyvelöknek, könyvvizsgálóknak, cégvezetőknek és más gazdasági szakembereknek készítették, a 2014-ben hatályba lépett új Polgári törvénykönyv rendelkezéseire alapozva. A mü két nagyobb részre bontható: az első rész a társasági jog, a második rész a szerződések a Polgári törvénykönyvben címet viseli. Kézikönyvméretű olvasmányos mủ, több helyen tábláza- 
tokkal, amelyek könnyítik a jogi elöírások megértését a nem jogász végzettségüek számára is. (Sz. G.)

- Nagykommentár a cégtörvényhez: nagykommentár a cégnyilvánosságról, a bírósági cégeljárásról és a végelszámolásról szóló 2006. évi V. törvényhez

BÁnKI-HoRvÁth Mária-Bodor Mária-Gál Judit-Koday Zsuzsanna-Rózsa ÉvaVEZEKÉNYI Ursula

Második, átdolgozott kiadás. Wolters Kluwer, Budapest, 2014

Kommentár. Terjedelem: 667. Bibliográfia: 657-667. ISBN 9789632954417

- A szerzők gazdasági és cégügyekkel foglalkozó bírák, gyakorlati szakértők. A kommentár müfajához igazodva a cégtörvény paragrafusait elemzik, magyarázzák és füznek hozzá véleményt. A kiadvány gyakorlati alkalmazhatósága érdekében az egyes szakaszokhoz igazodva bemutatják a hazai joggyakorlatot is, kiegészítve publikált bírói döntésekkel, elvi bírósági határozatokkal, közigazgatási-gazdasági döntvényekkel. A kommentár gazdag függelék- és mellékletgyüjteményt is tartalmaz. (F. P. P.)

- A polgári jog alapjai I.

Boóc Ádám

Patrocinium, Budapest, 2014

Egyetemi jegyzet. Terjedelem: 217. Bibliográfia: 211-217. ISBN 9786155337659

- A szerző egyetemi oktató. A kötet a Károli Gáspár Református Egyetem ÁJK-n folyó, felsőfokú jogiasszisztens-képzés számára készült. A magánjog általános tanaival, azon belül is különösen a személyek jogával (beleértve a jogi személyek jogát), a dologi joggal és külön fejezetben az ingatlan-nyilvántartás jogával foglalkozik, az új Ptk. alapján. Mindazonáltal nagyobb hangsúlyt fektet a dogmatikai alapokra, és a gyakorlat igényeit is jelentős mértékben igyekszik figyelembe venni. A jegyzet nagyban támaszkodik a korábbi, több kiadást megélt Előadásvázlatok a polgári jog általános tanaiból címü munkára. (T. E.)

- Nemzetközi magánjog: általános rész

BuRIÁn László

Pázmány Press, Budapest, 2014

Tankönyv. Terjedelem: 229. Bibliográfia nincs. ISBN 9789633081464

- A szerző a Pázmány Péter Katolikus Egyetem tanára. A tankönyvet abból a célból készítette el, hogy a joghallgatók számára rendelkezésre álljon egy olyan egységes munka, amely tartalmazza a nemzetközi magánjog szabályanyagát, elválasztva a nemzetközi gazdasági kapcsolatok jogától. E tankönyv a nemzetközi magánjog általános részét tárgyalja, nagy hangsúlyt fektetve a nemzetközi magánjog sajátos intézményeinek megértéséhez nélkülözhetetlen tudománytörténetre, továbbá a releváns gyakorlati példákra. A tananyag a nemzetközi magánjog különös részét tartalmazó kötettel válik teljessé. (Cs. R.) 
- Arbitrando et curriculum bene deligendo: ünnepi kötet Horváth Éva 70. születésnapja alkalmából

Burián László-Szabó Sarolta (szerk.)

Pázmány Press, Budapest, 2014

Tanulmánykötet. Terjedelem: 251. Bibliográfia a lábjegyzetekben.

ISBN 9789633082140

- A szerzők a hazai jogászélet neves és elismert képviselői, akik Horváth Éva, a nemzetközi választottbíráskodás meghatározó alakjának hetvenedik születésnapja alkalmából készítették el műveiket. A könyv tizenhét tanulmányt tartalmaz, köztük angol és német nyelvüeket is. Témájukat tekintve elsősorban a választottbíróságokkal és a nemzetközi magánjoggal foglalkoznak. A téma iránt érdeklődőknek mindenképp hasznos lehet ezen publikációk megismerése, mivel ebben a kérdéskörben meglehetősen kevés szakirodalom áll rendelkezésre. Az alkotások ezenfelül rendkívül aktuális kérdéseket is boncolgatnak, mint például az új Ptk. értékelése vagy a tisztességtelen fogyasztói szerződések. (F. P. P.)

- A jogi személyek szabályai a 2013. évi V. törvény alapján: az új Polgári törvénykönyv szövegének rövid magyarázata: átdolgozott változat a 2014. évi törvénymódositások figyelembevételével

CsEHI Zoltán

Menedzser Praxis, Budapest, 2014

Kézikönyv. Terjedelem: 167. Bibliográfia: 168. ISBN 9789638998675

- A szerző a Pázmány Péter Katolikus Egyetem tanára, ügyvéd. A kézikönyv a 2014. március 15-én hatályba lépett új Polgári törvénykönyv rövid magyarázatát, és elsődlegesen a lényegi összefüggések megvilágítását kívánja az olvasó elé tárni. A kötet lényegre törő, a törvény szövegéhez kapcsolódó tömör magyarázatokat tartalmaz, érthetővé és alkalmazhatóvá téve a törvényszöveget. Hasznos lehet mind a laikus, mint a jogtudó, polgári joggal foglalkozó szakemberek számára. (Cs. E.)

- A személyiség és a média a polgári és a büntetöjogban: az új Polgári Törvénykönyvre és az új Büntetö Törvénykönyvre tekintettel Csehi Zoltán-Koltay András-Navratyil Zoltán (szerk.)

CompLex, Budapest, 2014

Kézikönyv. Terjedelem: 467. Bibliográfia nincs. ISBN 9789632953861

- A szerzők egyetemi oktatók és gyakorló jogászok. A kötet az MTA Bölcsészettudományi Kutatóközpontja és az NMHH Médiatanács Médiatudományi Intézete együttmüködéséből született. Célja, hogy áttekintést és eligazítást nyújtson a személyiségvédelem és a média bonyolult kapcsolatrendszerében. A régi és új polgári és büntető törvénykönyvek dogmatikai alapvetéseiböl kiindulva, a releváns nemzetközi és hazai bírói gyakorlat segítségével vázolja fel a témakör izgalmas kérdéseit. A munka első része a Ptk.-ban nevesített személyiségi jogoknak a szólásszabadság tükrében való bemutatását tartalmazza; a második rész a személyiségi jogok sérelmének polgári jogi és polgári eljárásjogi következményeit elemzi; a harmadik egység a büntető anyagi jog és a szólásszabadság összefüggéseit tárja fel, és külön tanulmány tér ki a büntetőeljárás nyilvánosságának (és abban a saj- 
tó által vállalt szerepnek) a fontosságára. A kötet nemcsak a gyakorló jogászok, hanem a téma iránt érdeklődő laikusok számára is hasznos olvasmány lehet, érthető és olvasmányos stílusa miatt. (T. E.)

- A védjegytörvény magyarázata

Faludi Gábor-Lukácsi Péter-Bacher Gusztáv (szerk.)

HVG-ORAC, Budapest, 2014

Kézikönyv. Terjedelem: 721. Bibliográfia: 707-712. ISBN 9789632582030

- A szerzők bírák, a Szellemi Tulajdon Nemzeti Hivatalának vezető szakemberei, ügyvédek, jogtanácsosok, szabadalmi ügyvivők és egyetemi oktatók. Kilenc nagy részt tartalmaz. Az első rész a védjegy jogi oltalmát, a feltétlen (abszolút) és viszonylagos (relatív) kizáró okok ismertetését tartalmazza. A második részben a Szellemi Tulajdon Nemzeti Hivatala kerül bemutatásra. A továbbiakban széles ismereteket kapunk a nemzetközi védjegyrendszerröl, a lajstromozásról. A munka foglalkozik a védjegyügyekben alkalmazott bírósági eljárás menetével; megismerhetjük az együttes és tanúsító védjegy fogalmát és szabályait. Részletezi a földrajzi árujelzőkre vonatkozó szabályozásokat is. (Sz. G.)

\section{- Jogi személyek a gazdasági forgalomban}

FÉzer Tamás-KÁrolyı Géza-PetKó Mihály-Törő Emese

Második, átdolgozott kiadás.

Menedzser Praxis, Budapest, 2014

Egyetemi jegyzet. Terjedelem: 245. Bibliográfia: 245-246. ISBN 9789630891066

- A szerzők a Debreceni Egyetem ÁJK oktatói. Könyvük célja, hogy a kereskedelmi jogot és a gazdasági élet szereplőire - azok között is kiemelten a gazdasági társaságokra - vonatkozó hatályos magyar joganyagot teljes körüen bemutassa. Az egyéni vállalkozás, az egyéni cég, a mezőgazdasági termelők, a speciális társaságok és a civil szektor jogával kiegészülve komplex módon vizsgálja gazdasági jogunk állapotát. A kiadvány kitekint az Európai Unió társasági jogot érintő jogalkotási tendenciáira is, bemutatva az EU jogának égisze alatt müködő szupranacionális társaságokat (SE, ege, SCE) is. (Cs. E.)

\section{- Nagykommentár a szerzői jogi törvényhez}

Gyertyánfy Péter (szerk.)

Harmadik, átdolgozott kiadás. Wolters Kluwer, Budapest, 2014

Kommentár. Terjedelem: 722. Bibliográfia: 685-695. ISBN 9789632953908

- A kommentár új kiadását a szerzői jogban nemzetközi szinten és a magyar jogi szabályozás szintjén folyamatosan zajló változás indokolja, így az utóbbi években megszületett új szerzői jogi szakegyezmények, uniós jogszabályok, az új magyar Ptk. szükségessé tették a korábbi kiadások aktualizálását. A kötetben a korábbinál hangsúlyosabban jelenik meg a joggyakorlat, az Európai Bíróság és a magyar bírói gyakorlat bemutatása révén. A kommentár felhívja a figyelmet arra, hogy a fejlődés során ma is ugyanolyan jelentőséget kap a szerzői jogi jogosultak és a felhasználók, valamint a közönség érdekei közötti egyensúly fenntartása és megújítása, mint korábban. A munka a magyar szerzői jogi szakirodalmat a korábbi- 
nál nagyobb mértékben építi be; a 2006 utáni hazai szerzői jogi tárgyú müvekröl pedig egy szinte teljes körü jegyzéket is tartalmaz. A kötet hasznos lehet mind a szerzői joggal elméletben, mind azzal a gyakorlatban foglalkozó szakemberek, kutatók számára. (T. E.)

- Az Európai Unió új és megújuló jogforrásainak szerepe a magyar magánjog fejlesztésében

Harsági Viktória-Raffai Katalin-Suri Noémi (szerk.)

(Sorozat: A Pázmány Péter Katolikus Egyetem Jog- és Államtudományi Karának Könyvei. Doktorandusz Tanulmányok; ISSN 2064-4078)

Pázmány Press, Budapest, 2014

Tanulmánykötet. Terjedelem: 240. Bibliográfia a lábjegyzetekben. ISBN 9789633081952

- A tanulmánykötet a 2014. március 14-én rendezett doktoranduszkonferencia alkalmával elhangzott előadások anyagát tartalmazza. A konferencián a nemzetközi magánjog és a polgári eljárásjog témakörében kutató doktoranduszok és doktorjelöltek a plenáris ülést követően három szekcióban tartották meg előadásaikat. A tanulmánykötet átfogó és széles körü képet ad az Európai Unió jogforrásainak kialakulásáról, szükségességéröl és a tagállamok általi alkalmazhatóságról, illetve az esetleges akadályokról. Mindezt a magyar magánjogra gyakorolt hatásának és alkalmazhatóságának tükrében. (Cs. E.)

\section{- Bevezetés a házasságjogba}

HÁRSFAI Katalin

Harmadik kiadás. Szent István Társulat, Budapest, 2014

Egyetemi jegyzet. Terjedelem: 155. Bibliográfia: 149-152. ISBN 9789632770796

- A szerző a Pázmány Péter Katolikus Egyetem oktatója, jogász, kánonjogász, teológus. A tankönyv joghallgatók számára készült, akik az egyetem tanterve szerint a katolikus egyház jogrendjének alapvonásaival is megismerkednek. A könyv alapozó jellegü, bevezeti a hallgatókat a házassági jog szabályozásának alapjaiba, ennek során megismerkedhetnek az alapvető fogalmakkal, jogintézményekkel. A szerző nagy jelentőséget tulajdonít a kánonjognak a házassági jog szabályozása körében. Célja a jogászi gondolkodásmód alakítása. A célkitüzésnek megfelelöen a kötet alapvető értékeket közvetít, világos és pozitív módon mutatja be a házasságjog előzményeként a házastársi szerelmet, $s$ annak a házasságban betöltött szerepét, ezzel is rámutatva a felelös emberi döntés fontosságára. (Cs. R.)

- Polgári jog: Családjog

Hegedüs Andrea

R.I.M.Á.K. Bt, Szeged, 2014

Tankönyv. Terjedelem: 400. Bibliográfia: 399-400. és a lábjegyzetekben. ISBN 9789630890137

- A szerző a Szegedi Tudományegyetem oktatója. A mü létrejöttét az új Ptk. hatálybalépése indokolta. A könyv immár az új kódexre építve kísérli meg összefoglalni a családjog teljes anyagát. A könyv nemcsak a Ptk. családjogra vonatkozó 
rendelkezéseit taglalja, hanem kitér A házasságról, a családról és a gyámságról szóló 1952. évi IV. törvényre is, aminek nagy szerepet tulajdonít. Az elméleti és gyakorlati magyarázatot követően megtalálható az új Ptk. Családjogi könyvének, valamint a Ptké. vonatkozó rendelkezéseinek a jogszabályszövege is. A kötet jól áttekinthető módon mutatja be a családjog teljes szabályanyagát, így a laikusok számára is érthető. (Cs. R.)

- Kommentár a lakástörvényhez: kommentár a lakások és helyiségek bérletére, valamint az elidegenítésükre vonatkozó egyes szabályokról szóló 1993. évi LXXVIII. törvényhez

HoRvÁTH Gyula

Második, átdolgozott kiadás.

CompLex, Budapest, 2014

Kommentár. Terjedelem: 272. Bibliográfia nincs. ISBN 9789632954332

- A szerző ügyvéd, az ingatlanjog szakértője, müve a lakástörvényhez füzött kommentár. A több mint húsz éve hatályba lépett lakástörvény előírásai közötti eligazodást kívánja segíteni, a klasszikus kommentári struktúrát követve. A normaszöveget követő tematikus rendben mutatja be a legújabb bírósági határozatokat, illetve utal a kapcsolódó polgári jogi és ingatlan-nyilvántartási jogi előírásokra is, ezzel segítve a téma áttekintését. Az első kiadást a folyóirat 2014/2. számában annotáltuk. (F. P. P.)

- Kommentár a társasházi törvényhez: kommentár a társasházakról szóló 2003. évi CXXXIII. törvényhez

HORVÁtH Gyula

Wolters Kluwer, Budapest, 2014

Kommentár. Terjedelem: 293. Bibliográfia nincs. ISBN 9789632954356

- A szerző ügyvéd, az ingatlanjog szakértője. Ez a mű a társasházakról szóló 2003. évi CXXXIII. évi törvényhez füzött kommentár. Ehhez hüen a müfaj megszokott felépítését követi, s szakaszonként elemzi a törvény szövegét. Törekszik a jogintézmények és a hozzájuk kapcsolódó teljes bírói gyakorlat, a publikált bírósági határozatok bemutatására is. Bemutatja a társasház-alapítás feltételeit, a társasház szerveinek müködését, a társasházzal kapcsolatos jogokat és kötelezettségeket. (F. P. P.)

- A szerződések érvénytelensége

KIss Gábor-SÁNDOR István

(Sorozat: Új magánjog sorozat; ISSN 2064-7514; 3.)

Második, hatályosított kiadás. HVG-ORAC, Budapest, 2014

Kézikönyv. Terjedelem: 338. Bibliográfia: 327-333. ISBN 9789632582320

- A szerzők - bírói, ügyvédi munkájuk mellett - elméleti szakemberek, egyetemi oktatók. A kézikönyv a szerződések érvénytelenségét az új Ptk. egészére vonatkozólag mutatja be: a semmisségi okokat a személyek jogában, a dologi jogban, a kötelmi jog általános és különös részében, a megtámadhatósági okokat a kötelmi jog általános részében. Kitér a kötelmi jog különös részében szabályozott egyes 
szerződések esetében előforduló tipikus érvénytelenségi okokra. Ezentúl a szerzők ismertetik a társasági szerződés érvénytelenségét, a fogyasztói szerződések érvénytelenségi okait, a fizetésképtelenségi jogban ismert eseteket. A jogkövetkezmények rendszerét, valamint az érvénytelenség perjogi vonatkozásait külön fejezetben mutatják be. A kötet elsősorban a joggyakorlat oldaláról tárja fel az érvénytelenség problémáit. $A$ végén tárgymutató segíti a könyv anyagában való eligazodást. (Cs. R.)

- Ingatlan-nyilvántartás

Kovács András

(Sorozat: Bírói Gyakorlat Füzetek; ISSN 2063-725X; 11.)

Opten, Budapest, 2014

Kommentár. Terjedelem: 217. Bibliográfia nincs. ISBN 9786155122026

- A szerző a Kúria közigazgatási és munkaügyi kollégiumának tanácselnöke. A sorozat, melynek jelen kötet is részét képezi, arra vállalkozik, hogy az egyszerü döntvénytárnál jóval többet, egy nagykommentárnál jóval célratöröbbet, emellett azonban könnyebben használhatót nyújtson az ingatlan-nyilvántartás témakörében. Jelen kötet kilenc fejezetre bomlik. Ezek a következők: az ingatlan-nyilvántartás és az ingatlan-nyilvántartást vezető szerv, a bejegyzési elv, az ingatlan-nyilvántartás nyilvánossága, a nyilvánkönyv közhitelessége, a rangsor elve, a rangsor és a ranghely, az okirati elv, a nyilvánkönyvi közbenső intézkedések, az ingatlan-nyilvántartás és a végrehajtás, a törlési és kiigazítási perek, a végrehajtási igényperek, a közigazgatási eljárásjog és a perjog. (Cs. R.)

- Az új Polgári Törvénykönyv föbb vonásai és újitásai - Az „Új Polgári Törvénykönyv elvi és tartalmi megismerését szolgáló képzéssorozat” c. projekt kiadványa Közigazgatási és Igazságügyi Hivatal, Budapest, 2014

Kézikönyv. Terjedelem: 459. Bibliográfia: 457-459. ISBN 9789638970565

- A kötet a Közigazgatási és Igazságügyi Hivatal szakmai vezetésével, EU-s ÁROPprojekt keretében készült. A hivatal belső közszolgálati továbbképzéseinek oktatási anyagaként szolgál. Az új Ptk. legfontosabb rendelkezéseit a korábbi Polgári Törvénykönyvhöz képesti eltérésekkel mutatja be, az új Ptk. könyvei szerinti szerkezetben. (T. E.)

- Polgári jogi alapok: Főiskolai jegyzet főiskolai szintủ igazságügyi igazgatási és MTB szakos, továbbá jogi felsőoktatási szakképzésben részt vevő hallgatók számára KRISTON Edit-PuszTAHELYI Réka-SápI Edit Második, átdolgozott kiadás. Novotni Alapítvány, Miskolc, 2014 Egyetemi jegyzet. Terjedelem: 304. Bibliográfia nincs. ISBN 9789639360822

- A szerzők a Miskolci Egyetem Polgári Jogi Tanszékének oktatói. A mü azoknak a nem jogász szakos hallgatóknak készült tananyag, akiknek a képzési követelmények az alapvető polgári jogi ismeretek elsajátítását írják elő. Ennek megfelelően a munka az ilyen képzések keretében oktatott polgári jogi tanulmányokhoz nyújt segítséget, és ehhez igazodik az inkább a normatartalomra összpontosító, elméleti alapokat kevéssé taglaló feldolgozásmód. Hét nagyobb fejezetből áll: jogi 
alaptannal kezdődik, ezt követően tárgyalja a személyek jogát, a szerzői jog és az iparjogvédelem alapjait, a dologi jog, a kötelmi jog és a családjog főbb rendelkezéseit. (Sz. G.)

- A magánjog általános tana

LÁBADY Tamás

Második kiadás. Szent István Társulat, Budapest, 2014

Tankönyv. Terjedelem: 258. Bibliográfia: 235-242. és a fejezetek végén.

ISBN 9789632774589

- A szerző a Pázmány Péter Katolikus Egyetem oktatója, az új Polgári Törvénykönyv egyik kodifikátora. Célja, hogy szilárd kiindulópontot adjon a hallgatóknak, oktatóknak, gyakorló jogászoknak arról, mit értünk magánjog alatt, melyek e jogág forrásai, milyen a rendszere. Magánjogunk fejlődéstörténetét, alapvető rendszertani sajátosságait, alapelveit mutatja be. Tudományosan megalapozott tankönyve nem kizárólag a magánjoggal, hanem az európai kultúra értékeivel kapcsolatos ismeretekkel is gazdagítja az olvasót. A kötet felépítése világos, átgondolt, követhető a magánjoggal még csak ismerkedő hallgatók számára is. A tananyagban való eligazodást a kötet végén található mutató segíti. A 2013-ban megjelent, első kiadást 2015/1. számunkban annotáltuk. (Cs. R.)

- A szerzői jog gyakorlati kérdései: válogatás a Szerzői Jogi Szakértői Testület szakvéleményeiből, 2010-2013; fennállásának 130. évfordulója alkalmából Legeza Dénes (szerk.)

Szellemi Tulajdon Nemzeti Hivatala, Budapest, 2014

Emlékkönyv. Terjedelem: 424. Bibliográfia a lábjegyzetekben. ISBN 9789639157767

- A szerzők a szerzői joggal foglalkozó gyakorlati szakemberek, illetve egyetemi oktatók, kutatók. A Szerzői Jogi Szakértő Testület múltja több mint 130 évre vezethető vissza, azóta foglalkoznak ugyanis szerzői jogi jogvitás ügyekkel. Szakkérdésekben adnak ki állásfoglalást a bíróságok, hatóságok számára. A testület állásfoglalásait bemutató kötetek sorában ez immár a hatodik, amelyik felhívja a figyelmet az egyre inkább életünk részévé váló elektronikus adathordozó eszközökre (mobiltelefon, tablet, számítógép), melyek szerzői jogi védelem alatt álló komponenseket tartalmaznak. A kötet két nagy részből áll: az első részben a szerzői jogi szakértés történetéről, a szerzői jogi perek bírói tapasztalatairól olvashatunk tanulmányokat, a második részben pedig a 2010-2013. években született szakvéleményekből kaphatunk ízelítőt. (Sz. G.)

- Magyar polgári jog: A személyi jog vázlata

LENKOvics Barnabás-SzÉKELY László

Harmadik, átdolgozott kiadás. Eötvös József Könyvkiadó, Budapest, 2014

Egyetemi jegyzet. Terjedelem: 154. Bibliográfia: 153-154. ISBN 9789639955585

- A szerzők egyetemi oktatók, illetve Lenkovics Barnabás az Alkotmánybíróság elnöke, Székely László az alapvető jogok biztosa. A kötet tárgyalja a személyi jog fogalmát és jelentőségét; az embert mint jogalanyt; a jogi személyeket, valamint a személyhez füződő jogokat. A szerzők a témát teljes részletességgel mutatják 
be. Ebből következőleg a joghallgatók számára kiváló alapot biztosítanak a személyek jogának elsajátításához. A kötet az állam- és jogtudományi karok hallgatóinak készült oktatási segédanyag. (Cs. R.)

\section{- Introduction to Digital Copyright Law: Textbook} Mezel Péter-Hajdú Dóra

Szegedi Tudományegyetem Állam- és Jogtudományi Kar, Szeged, 2014 Egyetemi jegyzet. Terjedelem: 147. Bibliográfia nincs. ISBN 9789633062500

- A szerzők egyetemi oktatók, kutatók. A kötet célja, hogy a digitalizációval mint a kultúra megőrzésével kapcsolatos folyamat által felmerülö újabb szerzői jogi kérdéseket angol nyelven bemutassa a hallgatóknak. A munka a leginkább aktuális kérdéseket tárgyalja, így foglalkozik a fájlcserélés problematikájával, az árva művek kérdéskörével, a web 2.0 jelenség és a szerzői jog kölcsönhatásával. Az elméleti, összehasonlító-elemző részeket a vonatkozó esetjog bemutatása egészíti ki. A szerzők szándéka szerint az írások segítenek az angolszász és a kontinentális szerzői jog megoldásai közötti eltérések megértésében. (T. E.)

- „Megújulás a jogi személyek szabályozásában”: tanulmányok az új Ptk. köréböl Miskolczi Bodnár Péter-Grad-Gyenge Anikó (szerk.)

(Sorozat: Acta Caroliensia Conventorum Scientiarum luridico Politicarum; ISSN 2063-4757; 9.)

KRE ÁJK, Budapest, 2014

Tanulmánykötet. Terjedelem: 258. Bibliográfia a lábjegyzetekben.

ISBN 9789639808553

- A szerzők egyetemi oktatók az ország különböző jogi karain. A Polgári Törvénykönyvről szóló 2013. évi V. törvény kapcsán nagymértékben kibővült a jogi személyek szabályanyaga, és megnőtt azoknak a normáknak a száma, amelyek valamennyi jogi személy esetében alkalmazásra kerülnek. Erre tekintettel a Kereskedelmi Jogot Oktatók Találkozója keretében tudományos ülésre került sor, melyen tizenkilenc elöadás hangzott el, hat föbb témakörben. Ezek a jogalkotási folyamat, a kodifikáció általános kérdései, a társasági jog egyes területeinek kodifikációja, a társasági jog és a Ptk. viszonya, a Ptk.-ban és az azon kívül szabályozott társasági jog, valamint a felelősség témaköre. A kötet az előadások nyomán a legnagyobb gyakorlati jelentőségü változásokat tekinti át. (Cs. E.)

\section{- Öröklési jog: anyagi jog}

Orosz Árpád-Weiss Emília-Sáriné Simkó Ágnes (szerk.)

(Sorozat: Új magánjog sorozat; ISSN 2064-7514; 4.)

HVG-ORAC, Budapest, 2014

Kézikönyv. Terjedelem: 193. Bibliográfia: 189-193. ISBN 9789632582498

- A szerzők elméleti és gyakorlati szakemberek, kúriai bírók, jogtudósok. A mű az öröklési jog új Ptk. által átalakított szabályozási rendszerét mutatja be, részletes magyarázatokkal, az új jogintézmények mélyreható elemzésével és a bírói gyakorlat várható változásaival. A könyv végigvezeti az olvasót az öröklési joghoz kapcsolódó minden fontosabb rendelkezésen: kiesés az öröklésből, írásbeli vég- 
rendelet, általános szabályok, szóbeli végrendelet és köteles rész. A kötet végén található függelékek a könyv gyakorlati használhatóságát segítik. (F. P. P.)

\section{- Tansegédlet a polgári jogi záróvizsgához}

SÁNDOR István-GHIRA Márton

Negyedik és ötödik, átdolgozott kiadások.

(Sorozat: Werbőczy-sorozat; ISSN 2062-2538)

Kötetek (4. kiadás):

[1.] „A” tételek. Terjedelem: 394. ISBN 9786155337499

[2.] „B” tételek. Terjedelem: 248. ISBN 9786155337505

[3.] „C” tételek. Terjedelem: 277. ISBN 9786155337512

Kötetek (5. kiadás):

[1.] „A” tételsor. Terjedelem: 438. ISBN 9786155337826

[2.] „B” tételsor. Terjedelem: 268. ISBN 9786155337833

[3.] „C” tételsor. Terjedelem: 260. ISBN 9786155337840

Patrocinium, Budapest, 2014

Egyetemi jegyzet. Bibliográfia az egyes tételek végén.

- A szerzők egyetemi oktatók, köteteik a joghallgatók polgári jogi záróvizsgára való felkészülésének a megkönnyítésére hivatottak, az új Ptk. rendelkezéseinek és az új Ptk. módosításainak megfelelően kerültek átdolgozásra. Az egyes tételekről egy rövid vázlatot adnak, ami után kötelező és ajánlott irodalmat kínálnak, és a kapcsolódó jogszabályok, főbb bírósági állásfoglalások szövegét is tartalmazzák a releváns mértékben. A kötet célja a polgári jogi egyetemi tankönyvek kiegészítése, tematikus vázlat nyújtása. A szerzők szándéka az, hogy az anyagot a további záróvizsga-időszakokra újból hatályossá tegyék, csökkentve a hallgatók bizonytalanságát a hatályos joganyagot illetően. 2014-ben is két különböző változat készült, a két záróvizsga-időszakra. (T. E.)

- Üzleti jog: a szerződésszegésekről és a gazdasági társaságokról gazdasági szakembereknek

Sáriné Simkó Ágnes (szerk.)

HVG-ORAC, Budapest, 2014

Kézikönyv. Terjedelem: 389. Bibliográfia a fejezetek végén.

ISBN 9789632582399

- A szerzők többsége a Budapesti Corvinus Egyetem Jogi Tanszékének oktatója, emellett gyakorló jogi szakember is. Jól átlátják a jogi és gazdasági kérdéseket egyaránt, ezzel könnyen értelmezhetővé teszik a joganyagot a nem jogász végzettségü, gazdasági szakembereknek is, akiknek egyébként az új Polgári Törvénykönyv értelmezése pluszmunkát és időt jelentene. A könyv négy nagyobb részt tartalmaz: az első részben az alapokat mutatja be, mint például a gazdasági alkotmány, jogi alaptan vagy a versenyjogi alapok. A második nagyobb rész a kötelmi jogot ismerteti részletesen; a harmadik rész a társasági jogba, a negyedik rész pedig a munkajogba ad betekintést. (Sz. G.) 
- A családjogi harmonizáció kérdései és lehetőségei Európában: a házasság, házasságon kívüli partnerkapcsolatok, szülöi státusz, közös szülői felelösség és kapcsolattartás területein

SzEIBERT Orsolya

HVG-ORAC, Budapest, 2014

Monográfia. Terjedelem: 246. Bibliográfia: 223-240. ISBN 9789632582337

- A szerző az Eötvös Loránd Tudományegyetem docense. A kötet egyetemi hallgatók, gyakorlati jogászok és kutatók számára ajánlott. A családjoggal kapcsolatos alapvető kérdéseket vizsgálja, érintve a legfontosabb jogintézményeket, mint a házasság, bejegyzett élettársi kapcsolat, élettársi viszony, a szülői státusz keletkezése, a közös szülői felügyelet, külön élő szülő és gyermek kapcsolata. A különböző jogintézmények bemutatásán túl az európai tendenciák is elemzésre kerülnek, továbbá az európai dokumentumok, uniós jogforrások, az Emberi Jogok Európai Bíróságának, az Európai Unió Bíróságának a vonatkozó döntései is. Szerephez jutnak az európai szintű jogegységesítő megközelítések, azon belül az Európai Családjogi Bizottság tevékenysége is. (Cs. R.)

- A házasság Európában a jogegységesitő törekvések tükrében

Szeibert Orsolya

ELTE Eötvös Kiadó, Budapest, 2014

(Sorozat: ELTE Jogi Kari Tudomány; ISSN 2060-9361; 24)

Monográfia. Terjedelem: 260. Bibliográfia: 241-256. ISBN 9789633122013

- A szerző az ELTE Állam- és Jogtudományi Karának oktatója. A hiánypótló alkotás célja annak bemutatása, hogy mit jelent a házasság jelenleg Európában, menynyiben egységes a házasság felfogása, és várható-e annak harmonikus, egybehangzó megközelítése. A mű érdekessége, hogy széles körű európai kitekintést tartalmaz, feldolgozva az Európai Családjogi Bizottság elveit, és önálló fejezetben tárgyalja a Családjogi modelltörvényt, az Emberi Jogok Európai Bíróságának idevonatkozó gyakorlatát, és kitér a jövő várható házassági jogi tendenciáira is. (F. P. P.)

\section{- A szellemi alkotások jogvédelme az Európai Unióban}

TATTAY Levente

(Sorozat: A Pázmány Péter Katolikus Egyetem Jog- és Államtudományi Karának Tankönyvei; ISSN 2060-0837)

Pázmány Press, Budapest, 2014

Tankönyv. Terjedelem: 416. Bibliográfia: 403-416. és a lábjegyzetekben.

ISBN 9789633082010

- A szerző a Pázmány Péter Katolikus Egyetem tanára. Tankönyve hat nagyobb részből áll; az első részben a szellemi alkotások uniós védelmének általános vonásai; a másodikban az iparjogvédelem és szerzői jog közös intézményrendszerének bemutatása találhatók. A harmadik rész az ipari tulajdon normatív szabályozásával és európai uniós bírósági gyakorlatával foglalkozik; ezt követi a szerzői jogi jogharmonizáció szabályozása és az Európai Bíróság gyakorlata. Az ötödik rész a nemzetek fölött álló közösségi rendszereket mutatja be; befejezésül az eu- 
rópai jogharmonizációnak a magyar jogfejlődésre gyakorolt hatásával foglalkozik a szellemi alkotásokra vonatkoztatva. (Sz. G.)

- Infokommunikációs jog II.

Tóth András (szerk.)

(Sorozat: Bethlen-sorozat; ISSN 2062-2546)

Második, átdolgozott kiadás. Patrocinium, Budapest, 2014

Tankönyv. Terjedelem: 180. Bibliográfia a lábjegyzetekben.

ISBN 9786155337857

- A szerzők egyetemi oktatók, akik emellett gyakorlati szakemberek is. Az infokommunikáció egy nagy terület, amely magában foglalja az alapvető, ún. tradicionális infokommunikációs jogokat, mint például a véleménynyilvánítás szabadsága, de a technika fejlődésével haladnia kell, és fel kell tárnia az internettel kapcsolatos alapjogi kérdéseket; ezek a témakörök alkotják a könyv első nagyobb részét is. A továbbiakban a szerzők hasznos ismereteket adnak át az érintett infokommunikációs jog közgazdasági és szerzői jogi vonatkozásáról is. A technikai fejlődés jegyében két nagyobb rész foglalkozik az elektronikus közigazgatással és külön az elektronikus aláírás szabályozási alapjaival. (Sz. G.)

- Unfair commercial practices: the long road to harmonized law enforcement Tóth Tihamér (szerk.)

(Sorozat: A Pázmány Péter Katolikus Egyetem Jog- és Államtudományi Karának Könyvei; ISSN 2061-7240; 21)

Pázmány Press, Budapest, 2014

Tanulmánykötet. Terjedelem: 192. Bibliográfia a lábjegyzetekben. ISBN 9789633081778

- A kötet a Budapesten, 2013. május 10-én megrendezett nemzetközi konferencia szerkesztett anyagait tartalmazza, szerzői ennek megfelelően különböző európai országok elméleti és gyakorlati szakemberei. Az angol nyelvü tanulmányok a tisztességtelen kereskedelmi gyakorlatot mutatják be a jogharmonizációs utakon, illetve esettanulmányokon keresztül. Felhívják a figyelmet a jogharmonizáció szükségességére és nehézségeire, valamint a kereskedelmi gyakorlat pozitív és negatív aspektusaira. (Cs. E.)

- Polgári jogunk alapvonásai

Török Gábor (szerk.)

Nemzeti Közszolgálati Egyetem, Budapest, 2014

Egyetemi tankönyv. Terjedelem: 259. Bibliográfia nincs. ISBN 9786155344527

- A kötet az NKE közszolgálati oktatást fejlesztő könyvcsaládjának része. A munka elkészülésében több, különböző karokon oktató szerző müködött közre. A szerzők célja, hogy az NKE hallgatói számára - akiknek a magánjogi tárgyak nem jelentik képzésük középpontját - megfelelő áttekintést nyújtsanak a magánjogi szabályokról, magánjogi gondolkodásmódot fejlesszenek ki bennük. A munka a polgári jog azon részeire helyezi a hangsúlyt, amelyek ismerete a közigazgatásban dolgozók számára is elengedhetetlen, így különösen a jogi személyek, a do- 
logi jog és a kötelmi jog témaköre került részletes kifejtésre, míg a magánjog többi területe csak ,jelzésszerüen” szerepel a kötetben. (T. E.)

- Felelösségtan

UJVÁRINÉ AnTAL Edit

Novotni Alapítvány, Miskolc, 2014

Egyetemi tankönyv. Terjedelem: 275. Bibliográfia: 260-270.

ISBN 9789639360921

- A szerző egyetemi oktató. A kötet az 1994-től átdolgozott kiadásokban megjelenő Felelősségtan címü jegyzet utódjának tekinthető, az új Ptk. felelősségtani rendszerét veszi alapul. A munka Novotni Zoltán szellemiségére épül. A kötet első fejezete a jogi felelősség és a polgári jogi felelősség alapkérdéseivel foglalkozik; a felelősségtan történeti fejlődését is bevonja elemzésébe. Kitér az új Ptk. kártérítési felelösségi rendszerére is. A kötet külön fejezetekben tárgyalja a szerződésen kívül okozott kárért való általános kártérítési felelősség szabályait, a kártérítési kötelezettség terjedelmét, az egyes speciális felelősségi alakzatokat, a szerződésszegéssel okozott kárért való felelősséget, a kártérítés elhatárolását más kötelemfakasztó tényállásoktól, és a polgári jogi kártérítés szabályainak más jogterületeken való alkalmazhatóságát. Az új Ptk.-ban újonnan megjelenő sérelemdíj intézményére külön figyelmet fordít a szerzö. $A$ kötet a jogászképzésben részt vevő hallgatók felkészülésének megkönnyítését célozza, remek áttekintést nyújt a felelösségtan rendszeréröl. (T. E.)

\section{- Tanulmányok az új Polgári Törvénykönyvhöz}

Vékás Lajos-Vörös Imre (szerk.)

Wolters Kluwer, Budapest, 2014

Tanulmánykötet. Terjedelem: 304. Bibliográfia nincs. ISBN 9789632954134

- A szerzők között vannak egyetemi oktatók, ügyvédek, bírák. A kötet a Jogtudományi Közlönyben 2013-ban indított cikksorozat darabjaiból készült összeállítás, az új Ptk. legfontosabb kérdésköreit fogják át, a polgári jog minden nagyobb részének változásairól szólnak. A szerzők egy része részt vett az új kódex előkészítésének valamely szakaszában, vagy aktívan végigkísérték az egész folyamatot, mások külső szemmel értékelték a magyar magánjogi fejlődés eredményeit. A tanulmányok felhívják a figyelmet a törvénykönyv megalkotásának hátterére, megmutatják a problémák lehetséges megoldásait, ismertetik a választott koncepció szabályozási indokait, kritikailag értékelik a Ptk. rendelkezéseit. A szerzők és szerkesztők célja az volt, hogy az egyszerủ szövegmagyarázatnál alaposabb, de a mélyenszántó dogmatikai, történeti elemzésnél konkrétabb szövegek szülessenek. (T. E.)

- Szerződések tára: az új Ptk. alapján

Wellmann György (szerk.)

(Sorozat: Új magánjog sorozat; ISSN 2064-7514)

HVG-ORAC, Budapest, 2014

Kézikönyv. Terjedelem: 762. Bibliográfia a lábjegyzetekben.

ISBN 9789632582221 
- A szerzök - kilenc ügyvéd és három kúriai tanácselnök - elméleti és gyakorlati szakemberek. A kötet az új Ptk. alapján összeállított mintegy 120 szerződésmintát felvonultató mü, amely iránymutatást biztosít az okiratszerkesztésben. Aktualitását az adja, hogy az új kódex alapjaiban megváltoztatott vagy létrehozott néhány jogintézményt, amelyekhez feltétlenül szükségeltetik az új módszerek és sémák áttekintése. Szerepelnek benne az adásvételi szerződések és azok altípusai, a vállalkozási, a fuvarozási, a szállítmányozási, a megbízási, a bizományi, a közvetítői, a használati és hitelszerződések, közérthető és áttekintő jellegú jogszabályi háttérelemzéssel együtt. (F. P. P.)

\section{VEGYES TÁRGYÚ TANULMÁNYKÖTETEK}

- Állam és magánjog: törekvések és eredmények az Európai Unió joga, a nemzetközi magánjog, polgári jog és polgári eljárásjog keresztmetszetében

Csehi Zoltán-Raffai Katalin (szerk.)

(Sorozat: A Pázmány Péter Katolikus Egyetem Jog- és Államtudományi Karának könyvei. Tanulmányok; ISSN 2061-7240; 20)

Pázmány Press, Budapest, 2014

Tanulmánykötet. Terjedelem: 196. Bibliográfia a lábjegyzetekben. ISBN 9789633081792

- A szerzők a hazai jogi karok oktatói, doktoranduszai. A Magánjogot Oktatók Egyesületének negyedik országos konferenciáját 2012. június 8-9-én a Pázmány Péter Katolikus Egyetem Jog- és Államtudományi Karán rendezték meg. A kötetben megjelenő tanulmányok ennek szerkesztett előadásai, amelyek három témakörben (polgári jog, polgári eljárásjog, európai jog-nemzetközi magánjog) mutatják meg az előadók kutatási részeredményeit, formálódó doktori dolgozatukat, valamint tanúi lehetünk a fiatal doktoranduszok útkeresésének is. A kötetben megjelenő tanulmányok átfogó képet adnak az állam és a magánjog viszonyáról. (Cs. E.)

- A világ mi magunk vagyunk...: Liber Amicorum Imre Vörös

Fekete Balázs-Horváthy Balázs-Kreisz Brigitta (szerk.)

HVG-ORAC, Budapest, 2014

Tanulmánykötet. Terjedelem: 660. Bibliográfia a lábjegyzetekben.

ISBN 9789632582559

- Vörös Imre egyetemi oktató, az MTA levelező tagja. Kutatási területei a versenyjog, a nemzetközi magánjog és nemzetközi gazdasági kapcsolatok joga, az európai jog és az alkotmányjog. A jogtudóst pályatársai, barátai, egykori és mostani munkatársai, valamint tanítványai ezzel a tanulmánykötettel köszöntik hetvenedik születésnapján. A több mint 40 szerző az ország valamennyi egyetemének oktatói, valamint az MTA TK Jogtudományi Intézetének munkatársai közül került ki. A témák között szerepel a munkajog, környezetjog, alkotmányjog éppúgy, mint a jogtudomány módszerei, de olvashatunk európai jogi tanulmányokat is. Egy ilyen alkalom a szerzők számára szabad témaválasztást tesz lehetővé, így a kötet a jogtudomány fősodrától kissé távolabb eső kérdésekkel is foglalkozhat, mint 
amilyenek a kontrollelmélet, az oroszországi restitúciós perek vagy a pergyorsító reformok Japánban. (L. N.)

- Global and Local Issues from the Aspects of Law and Economy: $9^{\text {th }}$ Batthyány Summer School Proceedings

Gömbös Csilla-Kálmán János-Keserü Barna Arnold (szerk.)

Universitas-Győr Nonprofit Kft., Győr, 2014

Tanulmánykötet. Terjedelem: 274. Bibliográfia a lábjegyzetekben és a tanulmányok végén. ISBN 9786155298462

- A szerzők a Batthyány Summer School előadói és résztvevői. A nyári egyetem megrendezésére Győrött, 2014. július 13. és 19. között került sor Global and Local Issues from the Aspects of Law, Economy and Other Social Sciences címmel. A rendezvény célja Közép- és Kelet-Európa jelenének és jövőjének a megvitatása volt. Az előadások a jog, a politikatudomány, a gazdaságtudomány és a szociológia köré csoportosultak, és ez a multidiszciplinaritás tükröződik vissza a köteten, amely 18 angol nyelvű tanulmányt tartalmaz hazai és külföldi szerzőktől egyaránt. A tanulmányok föként a nemzetközi, európai uniós és a nemzeti (például magyar, lett) kérdéseket elemeznek, de a helyi szint (például Krakkó) is megjelenik bennük. A tanulmányok elsősorban a fenntartható fejlödéshez, a nemzetközi gazdasági kapcsolatok jogához, valamint az Európai Unióhoz kapcsolódnak. (B. Á.)

- Ünnepi kötet Dr. Molnár Imre egyetemi tanár 80. születésnapjára Homoki-Nagy Mária (szerk.)

(Sorozat: Acta Universitatis Szegediensis; ISSN 0324-6523; Acta juridica et politica, ISSN 0563-0606; 76.)

SZTE, Szeged, 2014

Tanulmánykötet. Terjedelem: 516. Bibliográfia a lábjegyzetekben.

ISBN 9789633063132

- A tanulmányok szerzői egyetemi oktatók. A tanulmánykötet 38 különálló tanulmányból áll, váltakozva magyar, német és angol nyelven, melyek Molnár Imre emeritus professzor 80 . születésnapja alkalmából készültek. A tanulmányok nagy része a professzor munkásságához igazodva a római jog tárgykörébe tartozik, de a kötetet színesítik ezenkívül jogtörténeti, kartörténeti és hatályos jogi tárgyú tanulmányok is, így bármely jogág iránt elhivatott érdeklődő számára hasznos mü lehet. A tanulmánykötet tartalmazza Molnár Imre rövid szakmai önéletrajzát és tudományos munkáinak jegyzékét is. (Sz. Zsa.)

- Liber Amicorum János Martonyi - Ünnepi kötet Martonyi János tiszteletére Nagy Csongor István (szerk.)

HVG-ORAC, Budapest, 2014

Tanulmánykötet. Terjedelem: 404. Bibliográfia a lábjegyzetekben. ISBN 9789632582245

- A tanulmánykötet a 70. születésnapját ünneplö Martonyi János tanári, jogtudósi munkásságának méltatásaként jelent meg. A kötet 28 szerző tanulmányát foglalja magában. A szerzők a hazai jogtudomány (a professzori kar és a fiatalabb gene- 
rációk) képviselöi, valamint külföldi kollégák. A tanulmányok német, angol, francia és magyar nyelven íródtak, tartalmukat tekintve szervesen kapcsolódnak Martonyi professzor munkásságához, visszatükrözik tudományos pályáját és megjelenítik az életpálya eredményeit elismerő baráti tisztelet és szeretet hangjait. A tanulmányok hét nagyobb téma köré szerveződnek: a nemzetközi magánjog, a választottbíráskodás, az EU-jog, a gazdasági kapcsolatok joga, a magánjog, a közjog, a jog-összehasonlítás és a jogelmélet körébe sorolhatóak. A tanulmányokat a köszöntők és Király Miklós utószava keretezi. (M. J.)

- Jogi alapismeretek I-II.

Péter Szabó Tamás

[Számozatlan,] átdolgozott kiadás. NYF, Nyíregyháza, 2014

Föiskolai jegyzet. Terjedelem: 222; 190. Bibliográfia nincs. ISBN 978615509792 8; 9786155097935

- A szerző bírósági titkár, főiskolai oktató. Jegyzete a Nyíregyházi Főiskola gazdálkodási szakos hallgatói számára készült, ennek megfelelően szerkezete az elöadásokat követi. Az alapfogalmaktól elindulva a jogalkotás rendjének és az Alaptörvény ismertetésével indulva alapozza meg a tételes jogi ismereteket. A gazdálkodási és menedzsmenti ismeretekhez kapcsolódva részletesebben mutatja be a polgári-, illetve kereskedelmi jog egyes területeit, de emellett alapvető ismereteket ad az EU jogáról és a gazdasági büntetőjogról is. (Sz. G.)

- A jogalkalmazás vitatott területei - a sajtó polgári jogi felelőssége Pribula László (szerk.)

Debreceni Egyetem Állam- és Jogtudományi Kar, Debrecen, 2014

Tanulmánykötet. Terjedelem: 130. Bibliográfia a lábjegyzetekben. ISBN 9789634737377

- A Debreceni Egyetem Állam- és Jogtudományi Karán 2013. október 18. napján megrendezésre került „A jogalkalmazás vitatott területei - Mit írhat meg a sajtó? A sajtó polgári jogi felelőssége" címü konferencia. A tanulmánykötet a konferencián elhangzott elöadások szerkesztett anyagát tartalmazza. A konferencia elöadói, egyben a kötetben szereplő tanulmányok szerzői tudományos szempontból és a gyakorlat nézőpontjából is feldolgozták témáikat. A polgári jogi felelősség mellett a büntetőjogi vetület, valamint az alkotmánybírósági gyakorlat bemutatása is jelen van, a személyiségi jogi perek, azon belül is a sajtóperek témáját pedig több aspektusból vizsgálták a szerzők. A modern sajtóval kapcsolatban felmerült konkrét jogesetek elemzése szintén a kötet részét képezi. (M. J.) 